University of Wollongong

Research Online

Faculty of Science, Medicine and Health -

Papers: part A

Faculty of Science, Medicine and Health

$1-1-2014$

\title{
Total synthesis of hyacinthacines B3, B4, and B 5 and purported \\ hyacinthacine B7, 7-epi-hyacinthacine B7, and 7a-epi-hyacinthacine B3 from a common precursor
}

\author{
Kongdech Savaspun \\ University of Wollongong, ks375@uowmail.edu.au \\ Christopher W. G Au \\ University of Wollongong, cwga289@uow.edu.au \\ Stephen G. Pyne \\ University of Wollongong, spyne@uow.edu.au
}

Follow this and additional works at: https://ro.uow.edu.au/smhpapers

Part of the Medicine and Health Sciences Commons, and the Social and Behavioral Sciences

\section{Commons}

\section{Recommended Citation}

Savaspun, Kongdech; Au, Christopher W. G; and Pyne, Stephen G., "Total synthesis of hyacinthacines B3, B4, and B 5 and purported hyacinthacine B7, 7-epi-hyacinthacine B7, and 7a-epi-hyacinthacine B3 from a common precursor" (2014). Faculty of Science, Medicine and Health - Papers: part A. 1702.

https://ro.uow.edu.au/smhpapers/1702

Research Online is the open access institutional repository for the University of Wollongong. For further information contact the UOW Library: research-pubs@uow.edu.au 
Total synthesis of hyacinthacines B3, B4, and B 5 and purported hyacinthacine B7, 7-epi-hyacinthacine B7, and 7a-epi-hyacinthacine B3 from a common precursor

\begin{abstract}
The total synthesis of hyacinthacines B3, B4, and B5 and purported hyacinthacine B7, 7-epi-hyacinthacine B7, and 7a-epi-hyacinthacine B3 from a common anti-1,2-amino alcohol precursor is described. These syntheses confirmed that the proposed structures and absolute configurations of hyacinthacines B3, B4, and B5 were correct and disclosed that the proposed structure of hyacinthacine B7 was incorrect. Our synthetic and spectroscopic studies suggest that the natural hyacinthacines B5 and B7 are the same compounds; however, without access to authentic samples this cannot be unequivocally proven.

\section{Keywords}

CMMB

Disciplines

Medicine and Health Sciences | Social and Behavioral Sciences

Publication Details

Savaspun, K., Au, C. W. G. \& Pyne, S. G. (2014). Total synthesis of hyacinthacines B3, B4, and B 5 and purported hyacinthacine B7, 7-epi-hyacinthacine B7, and 7a-epi-hyacinthacine B3 from a common precursor. Journal of Organic Chemistry, 79 (10), 4569-4581.
\end{abstract}


Total Synthesis of Hyacinthacines $\mathbf{B}_{3}, \mathbf{B}_{4}$, and $\mathbf{B}_{5}$, Purported Hyacinthacine $\mathbf{B}_{7}$, 7-epiHyacinthacine $\mathbf{B}_{7}$, and 7a-epi- Hyacinthacine $\mathbf{B}_{3}$ from a Common Precursor

Kongdech Savaspun, Christopher W. G. Au and Stephen G. Pyne*

School of Chemistry, University of Wollongong, Wollongong, New South Wales, 2522, Australia.

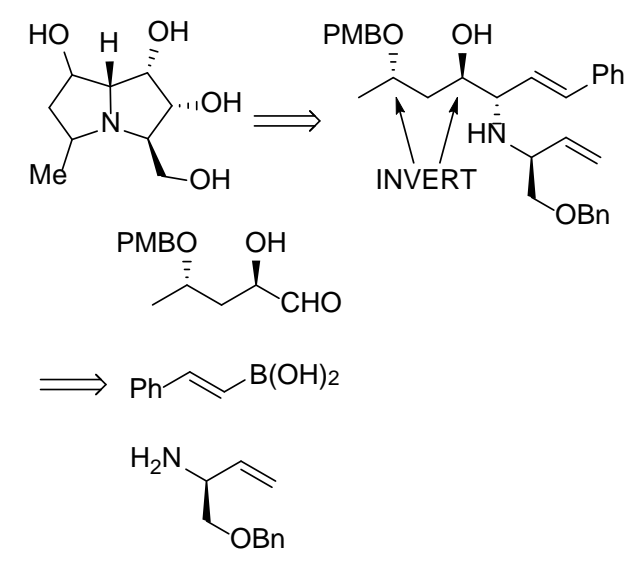

\begin{abstract}
The total synthesis of hyacinthacines $\mathrm{B}_{3}, \mathrm{~B}_{4}$, and $\mathrm{B}_{5}$, purported hyacinthacine $\mathrm{B}_{7}$, 7-epi- hyacinthacine $\mathrm{B}_{7}$, and 7a-epi- hyacinthacine $\mathrm{B}_{3}$ from a common anti-1,2-amino alcohol precursor is described. These syntheses confirmed that the proposed structures and absolute configurations of hyacinthacines $B_{3}, B_{4}$, and $B_{5}$ were correct and disclosed that the proposed structure of hyacinthacine $\mathrm{B}_{7}$ was incorrect. Our synthetic and spectroscopic studies suggest that the natural hyacinthacines $B_{5}$ and $B_{7}$ are the same compounds; however without access to authentic samples this cannot be unequivocally proven.
\end{abstract}




\section{INTRODUCTION}

The hyacinthacine alkaloids are a relatively recent addition to the group of polyhydroxylated 3-hydroxymethylpyrrolizidine natural products. ${ }^{1,2}$ These alkaloids, along with the other related polyhydroxylated pyrrolidine, piperidine, indolizidine and nortropane alkaloids, often have specific glycosidase inhibitory activities. Some of these, and their more drug like derivatives, have been identified as potential antiviral, anticancer, antidiabetic and antiobesity drugs. ${ }^{1}$ Nineteen hyacinthacine alkaloids of general structure $\mathbf{1}$ (Fig. 1) have been isolated. The first came from the Hyacinthaceae family of plants (Hyacinthoides nonscripta, the common bluebell) ${ }^{3 \mathrm{a}}$ while the others have been isolated from the bulb extracts of Muscari armeniacum, ${ }^{3 \mathrm{~b}}$ Scilla campanulata, ${ }^{3 \mathrm{a}}$ S. sibirica, ${ }^{3 \mathrm{c}}$ and S. sociali. ${ }^{3 \mathrm{~d}}$ Related alkaloids, having extended side chains at C-5, have been isolated from S. peruviana. ${ }^{3 \mathrm{e}}$ In general these alkaloids show relatively weak glycosidase inhibitory activities with the best only having moderate activities ( $\mathrm{IC}_{50}$ ca $5-20 \mu \mathrm{M}$ ) against $\alpha$ - and $\beta$-glucosidases, $\beta$-galactosidases, and amylglucosidases. ${ }^{3 a-d}$ These alkaloids have been classified as hyacinthacines $A_{1-7}$, $\mathrm{B}_{1-7}$, and $\mathrm{C}_{1-5}$ based on their total number of hydroxy and hydroxymethyl groups in the ring $\mathrm{B}^{3 \mathrm{a}-\mathrm{d}}$ The structures and relative configurations of these natural products have been assigned based solely on NMR and MS spectroscopic analysis with the only X-ray crystalographic study made on synthetic material. ${ }^{4}$ The synthesis of these alkaloids has confirmed many of these structures and allowed assignment of their absolute configurations. Most of these syntheses have involved starting materials from Nature's chiral pool (carbohydrates, ${ }^{5 \mathrm{a}-\mathrm{o}}$ amino acids, ${ }^{5 \mathrm{p}-\mathrm{r}}$ and diethyl tartrate ${ }^{5 \mathrm{~s}-\mathrm{u}}$ ). Others include an enzymatic resolution step followed by diastereoselective 
synthesis, $^{4,6}$ a [2+2]-cycloaddition approach using a chiral auxiliary ${ }^{7}$ and a chemoenzymatic synthesis using an aldolase. $^{8}$ The synthesis of epimers ${ }^{9}$ and a racemic synthesis have also been reported. ${ }^{10}$ Synthetic studies have revealed that the proposed structures of hyacinthacines $\mathrm{B}_{7},{ }^{11} \mathrm{C}_{3},{ }^{5 \mathrm{q}}$ and $\mathrm{C}_{5}{ }^{9 \mathrm{f}}$ are incorrect. Thus new methods for the synthesis of these compounds is important not only to confirm their structures but also to provide analogues for structure-activity relationship studies. In an earlier communication we reported the development of a new synthetic strategy towards these alkaloids and the first synthesis of hyacinthacine $B_{3} 2$ from (2S)-4penten-2-ol. ${ }^{11}$ This synthesis confirmed the structural identity and the absolute configuration of this alkaloid. The synthesis of the proposed structure of hyacinthacine $B_{7} 3$, the $C-5$ epimer of hyacinthacine $B_{3}$, was also described starting from (2R)-4-penten-2-ol, which indicated that the structure proposed for the natural product was incorrect. ${ }^{11}$ We report here the full details of the synthesis of these compounds and the synthesis of hyacinthacine $\mathrm{B}_{5} \mathbf{5}$ and the analogue 7-epihyacinthacine $B_{7} \mathbf{6}$, a possible correct structure for natural hyacinthacine $B_{7}$, from (2S)-4-penten-2-ol as a common chiral synthetic precursor. Two side products from the synthesis of 5 were hyacinthacine $B_{4} 4$ and $7 a-e p i$ - hyacinthacine $B_{3}$. These syntheses confirmed the structures and absolute configurations of natural hyancinthacines $B_{3}, B_{4}$, and $B_{5}$. From further analysis of their NMR spectroscopic data, and those of the other epimeric compounds that we have prepared, we propose that the structure of naturally occuring hyacinthacine $\mathrm{B}_{7}$ has been missassigned and is actually hyacinthacine $B_{5}$. Unfortunately, the unavailabilty of these natural products does not allow us to be unequivocal about this structural reassignment. 

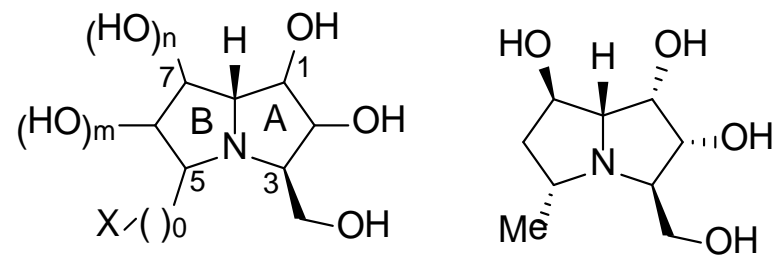

$$
\begin{gathered}
1 \\
\mathrm{x}=\mathrm{H}, \mathrm{OH} \\
\mathrm{n}, \mathrm{m}, \mathrm{o}=0,1
\end{gathered}
$$

hyacinthacine $\mathrm{B}_{3}$<smiles>C[C@@H]1C[C@H](O)[C@H]2[C@@H](O)[C@@H](O)[C@@H](CO)N21</smiles>

hyacinthacine $B_{7}$

3<smiles>C[C@@H]1C[C@@H](O)[C@H]2[C@@H](O)[C@H](O)[C@@H](CO)N21</smiles>

hyacinthacine $\mathrm{B}_{4}$<smiles>C[C@@H]1C[C@@H](O)[C@H]2[C@@H](O)[C@@H](O)[C@@H](CO)N21</smiles>

hyacinthacine $B_{5}$

5

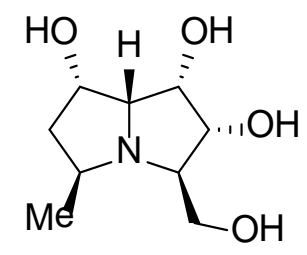

7-epi-hyacinthacine $\mathrm{B}_{7}$

6

Figure 1. General structure of the hyacinthacine alkaloids and target molecules

\section{RESULTS AND DISCUSSION}

\section{Synthesis of hyacinthacine $B_{3}$}

Our retrosynthetic analysis of hyacinthacines $\mathrm{B}_{3}, \mathrm{~B}_{5}, \mathrm{~B}_{7}$, and 7-epi-hyacinthacine $\mathrm{B}_{7}$ suggested that the 1,2-anti-amino alcohol 7, which we used earlier as a precursor for the total synthesis of hyacinthacine $\mathrm{B}_{3} 2,{ }^{11}$ could serve as a useful common intermediate to the total synthesis of all four target compounds (Scheme 1). We anticipated that the configurations at C-2 and/or C-4 in 7 could be sequentially inverted to allow ready access 
to each of these related synthetic targets. In our earlier synthesis of hyacinthacine $B_{3} \mathbf{2}$ the $\alpha$-hydroxy aldehyde $\mathbf{8}$, or its cyclic acetal derivative, was prepared by an asymmetric dihydroxylation $(\mathrm{ADH})$ reaction of the vinyl sulfone 11 (Scheme 1). ${ }^{11,12}$ This aldehyde was not isolated but treated with a mixture of $\beta$-styrenyl boronic acid $\mathbf{9}$ and the chiral allylic amine $\mathbf{1 0}^{13}$ under boronic acid Mannich reaction conditions ${ }^{14}$ to give the 1,2 -antiamino alcohol 7. ${ }^{11}$ However we found that this method was not readily amenable to the scale up synthesis of $\mathbf{7}$ that was required here and the best overall yield of $\mathbf{7}$ that we could obtain on a several hundred milligram scale was $37 \%$ for the two steps. We thus devised an alternative synthesis of the aldehyde $\mathbf{8}$ from the alkene $\mathbf{1 2 .}$

Scheme 1. Retrosynthetic analysis of targets 2, 3, 5, and 6.

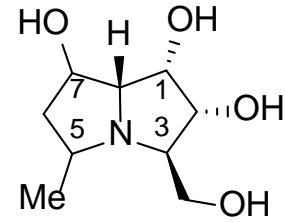

2, 3, 5 or 6

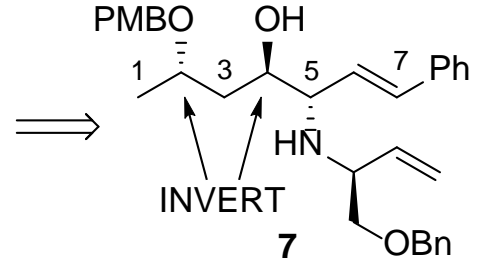

7

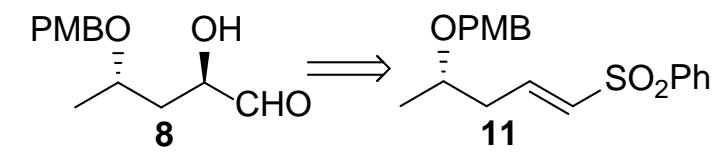

or

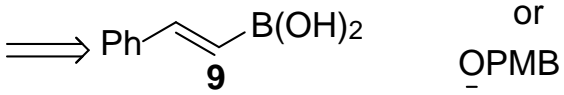

$\mathrm{H}_{2} \mathrm{~N}$<smiles>C=CC(COc1ccccc1)CC(C)CBr</smiles>

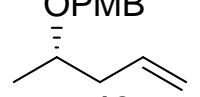

12

The ADH reactions of the alkene 12 using AD-mix- $\beta$ ((1 mol \% (DHQD) ${ }_{2}$ PHAL, $t$ $\mathrm{BuOH} / \mathrm{H}_{2} \mathrm{O}$ (1:1), methanesulfonamide (1 mol equiv) at rt or at $3{ }^{\circ} \mathrm{C}$ over $3 \mathrm{~d}$ gave the desired diol 13, however in poor yields (15\% and $24 \%$, respectively) with no diastereoselectivity ( $\mathrm{dr}=1: 1)$ (Scheme 2 ). The $\mathrm{dr}$ of $\mathbf{1 3}$ was conveniently determined by 
${ }^{1} \mathrm{H}$ NMR analysis, the desired $2 R$ diastereomer showed a resolved doublet resonance at $\delta$ 4.54 ( $J 11.5 \mathrm{~Hz}$, OCHHPMP) while the undesired 2S diastereomer had a resolved doublet resonance at $\delta 4.57$ ( $J 11.5 \mathrm{~Hz}$, OCHHPMP). The yields and diastereoselectivities were enhanced significantly when DHQD-IND or (DHQD) $)_{2}$ PYR were used instead of (DHQD) $)_{2}$ PHAL as the chiral ligand at $3{ }^{\circ} \mathrm{C}$ over $3 \mathrm{~d}(65 \%$ yield, $\mathrm{dr}=3: 1$ and $61 \%$ yield and $\mathrm{dr}=4: 1$, respectively). ${ }^{15}$ However, the yield of the diol 13 was nearly quantitative (99\%) when the latter reaction was run at $3{ }^{\circ} \mathrm{C}$ for $3 \mathrm{~d}$ in $t-\mathrm{BuOH} / \mathrm{H}_{2} \mathrm{O}$ (1:2) without compromising the diastereoselectivity $(\mathrm{dr}=4: 1)$. While these diastereomeric diols could be separated by careful column chromatography it proved more convenient to take the diastereomeric mixture through to the 1,2-anti-amino alcohol 7 and purify the reaction product mixture at this stage. Thus the diol $13(\mathrm{dr}=4: 1)$ was oxidized with TEMPO and sodium hypochlorite in a two phase system (sat. aqueous $\mathrm{NaHCO}_{3} / \mathrm{CH}_{2} \mathrm{Cl}_{2}$ ) at $0{ }^{\circ} \mathrm{C}$ for 30 $\min ^{16}$ to give a product mixture which we assumed was a mixture of hemiacetals $\mathbf{1 4}$ since NMR analysis showed no aldehyde signals (Scheme 2). The unpurified material was then immediately treated with $\beta$-styrenyl boronic acid $\mathbf{9}$ and the chiral allylic amine $\mathbf{1 0}$ in $\mathrm{CH}_{2} \mathrm{Cl}_{2}$ solution at $\mathrm{rt}$ for $2 \mathrm{~d}{ }^{14}$ The crude reaction mixture was purified by column chromatography to give the 1,2-anti-amino alcohol 7 in $73 \%$ overall yield for the two steps as essentially a single diastereomer $(d r=95: 5$, Scheme 2$)$. The minor diastereomer of $\mathbf{7}$, that could possibly arise from the reaction of $2 S-\mathbf{1 3}$ with $\mathbf{9}$ and $\mathbf{1 0}$, could not be isolated from the above mentioned column chromatography. The ${ }^{1} \mathrm{H}$ and ${ }^{13} \mathrm{C}$ NMR spectra of 7 matched closely with those of compound 7 that we prepared earlier starting from the vinyl sulfone $11 .^{11}$ 
In order to prepare the A-ring of hyacinthacine $\mathrm{B}_{3} 2$, via a ring closing metathesis (RCM) reaction of the diene $\mathbf{7}$, the 1,2 -amino alcohol moiety of $\mathbf{7}$, which may deactivate the ruthenium catalyst by coordination, was protected first as its oxazolidinone derivative $\mathbf{1 5}$ (66\% yield) by treatment with triphosgene/ $\mathrm{Et}_{3} \mathrm{~N}$ (Scheme 3). ${ }^{1} \mathrm{H}$ NMR analysis of $\mathbf{1 5}$, showed $J_{4,5}=8.1 \mathrm{~Hz}$, the magnitude of this vicinal coupling constant was consistent with the 4,5-cis relative stereochemistry of $\mathbf{1 5},{ }^{14 \mathrm{c}}$ this assignment was further established from the NOESY correlation between $\mathrm{H} 4$ and H5 (Scheme 3). These results also confirmed the anti-configuration assigned to the 1,2-amino alcohol moiety in $\mathbf{7}$ which was expected

Scheme 2. Synthesis of the anti-1,2-amino alcohol 7.
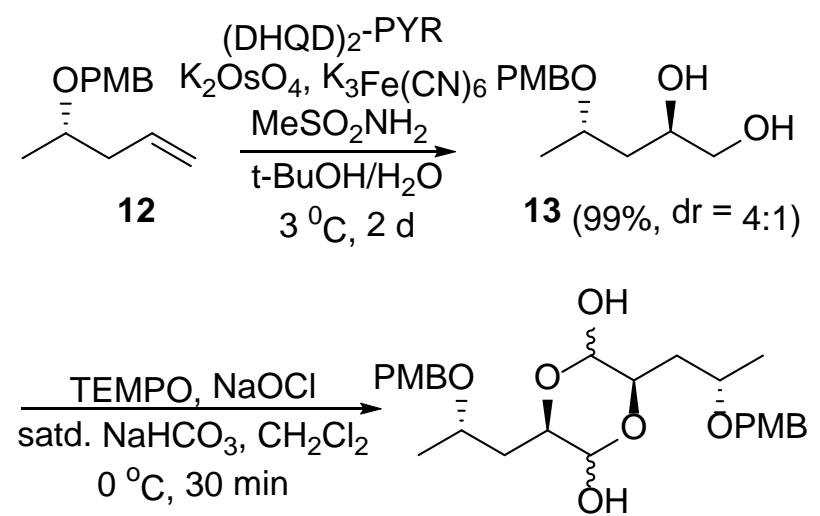

14
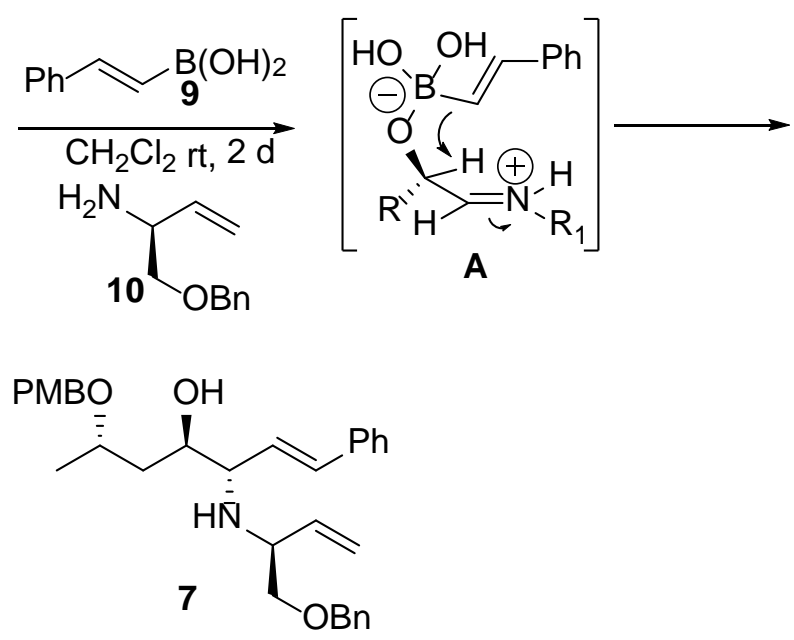

(73\% for 2 steps) 
based upon mechanistic considerations and literature precedent (see intermediate $\mathbf{A}$ in Scheme 2$)^{14}$

Scheme 3. Synthesis of hyacinthacine $\mathrm{B}_{3} 2$.
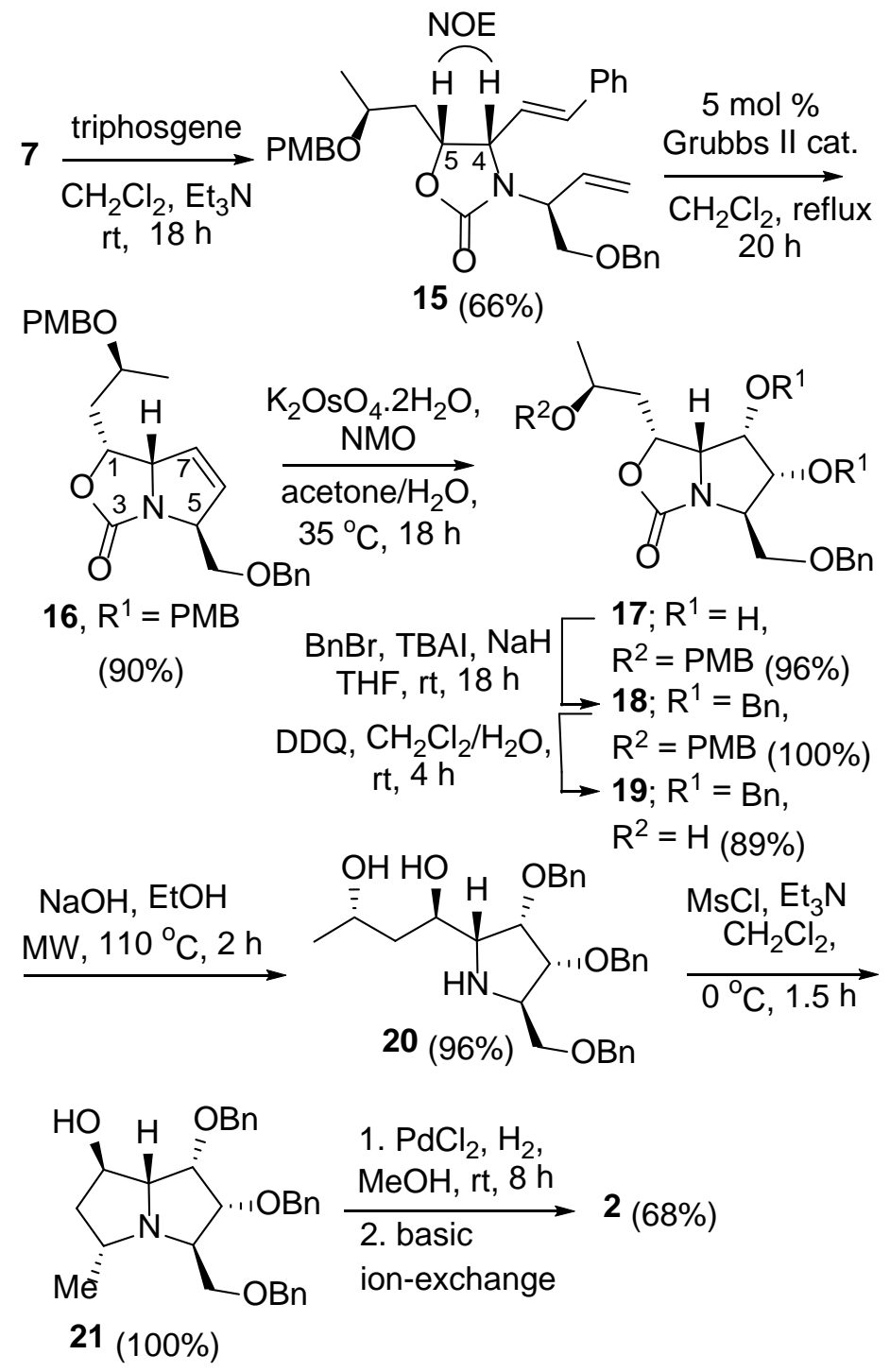

A ruthenium catalyzed RCM reaction of $\mathbf{1 5}$, using 5 mol\% Grubbs' second generation catalyst, gave the pyrrolo[1,2-c]oxazol-3-one $\mathbf{1 6}$ in 90\% yield. Based on our previous work, ${ }^{17,18 \mathrm{a}}$ and that of Parsons, ${ }^{18 \mathrm{~b}, \mathrm{c}}$ we expected that the syn-dihydroxylation (DH) of $\mathbf{1 6}$ would furnished the corresponding $6 \alpha, 7 \alpha$-diol $\mathbf{1 7}$ with the desired configuration for the 
synthesis of the target alkaloid. In the event, the Os(VIII)-catalysed syn-DH of $\mathbf{1 6}$ provided the desired diol $\mathbf{1 7}$ as a single diastereoisomer in 96\% yield. Earlier we explained this high level of diastereoselectivity based on stereoelectronic effects and an examination of the HOMO of $\mathbf{1 6}$ about the alkene moiety. ${ }^{11}$ The non-bonding orbital bearing the electron pair on the $\mathrm{N}$-atom overlaps more effectively with the $\pi$-system of the alkene moiety on the concave face ( $\alpha$-face) of the molecule making this more hindered face more prone to dihydroxylation. ${ }^{18 \mathrm{~b}, \mathrm{c}}$ The $\beta$-benzyloxymethyl substituent at C-5 also contributes partially to the diastereofacial selectivity, since the DH of a similar substrate which lacked this C-5 substituent was less diastereoselective. ${ }^{19}$ Importantly, the pyrrolo[1,2-c]oxazol-3-one $\mathbf{1 6}$ has allowed us to secure the desired 2,3-diol configuration of the alkaloid 2, on essentially a trans-2,5-disubstituted-2,5-dihydropyrrole A-ring precursor, that would otherwise be expected to be problematic. Compound $\mathbf{1 7}$ was readily converted to the amino diol $\mathbf{2 0}$ (Scheme 3) by three efficient consecutive reactions: (i) a bis-O-benzylation reaction to give 18 (100\% yield); (ii) O-PMB deprotection of $\mathbf{1 8}$ with DDQ under aqueous conditions ${ }^{11}$ to give 19 (89\% yield); and (iii) base hydrolysis of 19 under microwave heating (96\% yield of 20). Treatment of $\mathbf{2 0}$ with 1.05 equivalents of $\mathrm{MsCl}^{4}$ under basic conditions $\left(\mathrm{Et}_{3} \mathrm{~N}\right)$ at $0{ }^{\circ} \mathrm{C}$ gave the pyrrolizidine 21 in $100 \%$ yield. Debenzylation of $\mathbf{2 1}$ under hydrogenolysis conditions using $\mathrm{PdCl}_{2} / \mathrm{H}_{2}{ }^{17}$ gave hyacinthacine $\mathrm{B}_{3} 2$ in 68\% yield after purification and neutralization by basic ionexchange chromatography (Scheme 3). The overall yield of 2 from 12 was $24 \%$. The ${ }^{1} \mathrm{H}$ and ${ }^{13} \mathrm{C}$ NMR spectral data of this compound matched very closely to those reported in the literature (see SI). ${ }^{3 \mathrm{~b}}$ The configuration assigned to this compound was confirmed by NOESY NMR studies (see SI). The optical rotation of this compound $\left([\alpha]_{D}^{23}+10.8\right.$ (c 
0.33, $\mathrm{H}_{2} \mathrm{O}$ )) was larger in magnitude but of the same sign to that reported (lit. ${ }^{3 \mathrm{~b}}[\alpha]_{\mathrm{D}}+3.3$ (c 0.31, $\mathrm{H}_{2} \mathrm{O}$ )). Thus this synthesis confirms the proposed structure and absolute configuration of hyacinthacine $\mathrm{B}_{3} 2$.

\section{Synthesis of the purported structure of hyacinthacine $B_{7}$ and 7-epi-hyacinthacine $B_{7}$}

The proposed structure of hyacinthacine $B_{7}$ (3) was prepared from 19 according to Scheme 4 (a). The unprotected secondary alcohol of 19 was converted to the 4nitrobenzoate derivative 22, with inversion of configuration, under Mitsunobu reaction conditions. ${ }^{20}$ Base hydrolysis of both the ester and oxazolidinone moieties of 22 was achieved under microwave heating conditions which furnished the amino diol 23 in 97\% yield. This compound was identical to the compound we prepared in our earlier synthesis of 23 starting from (2R)-4-penten-2-ol. ${ }^{11}$ Treatment of $\mathbf{2 3}$ with 1.05 equivalents of $\mathrm{MsCl}$ under basic conditions $\left(\mathrm{Et}_{3} \mathrm{~N}\right)$ at $0{ }^{\circ} \mathrm{C}$ gave the pyrrolizidine 24 in $77 \%$ yield after purification by column chromatography. Debenzylation of $\mathbf{2 4}$ under hydrogenolysis conditions using $\mathrm{PdCl}_{2} / \mathrm{H}_{2}{ }^{14}$ gave the purported structure of hyacinthacine $\mathrm{B}_{7}$ (3) in $68 \%$ yield after purification and neutralization by basic ion-exchange chromatography (Scheme 4 (a)). Of significant concern was that the ${ }^{1} \mathrm{H}$ and ${ }^{13} \mathrm{C}$ NMR spectral data of

synthetic 3 did not match with those reported for hyacinthacine $B_{7}$ (see SI). ${ }^{3 \mathrm{~d}}$ Further its specific rotation $[\alpha]_{D}^{24}+31.2\left(c 0.20, \mathrm{H}_{2} \mathrm{O}\right)$ was significantly different and of the opposite sign to that of the natural product $\left([\alpha]_{D}-4.4\left(c 0.20, \mathrm{H}_{2} \mathrm{O}\right){ }^{3 \mathrm{~d}}\right.$ NOESY NMR analysis of our synthetic compound clearly indicated that it had the correct relative configuration, significantly, a NOESY correlation was observed between H-5 and H-7 in 3 (See ref 11 for details) but this was not reported for hyacinthacine $\mathrm{B}_{7}$ in the original isolation paper. 
Scheme 4. (a) Synthesis of the purported structure of hyacinthacine $B_{7}$ (3) and (b) 7-epihyacinthacine $\mathrm{B}_{7}(\mathbf{4})$
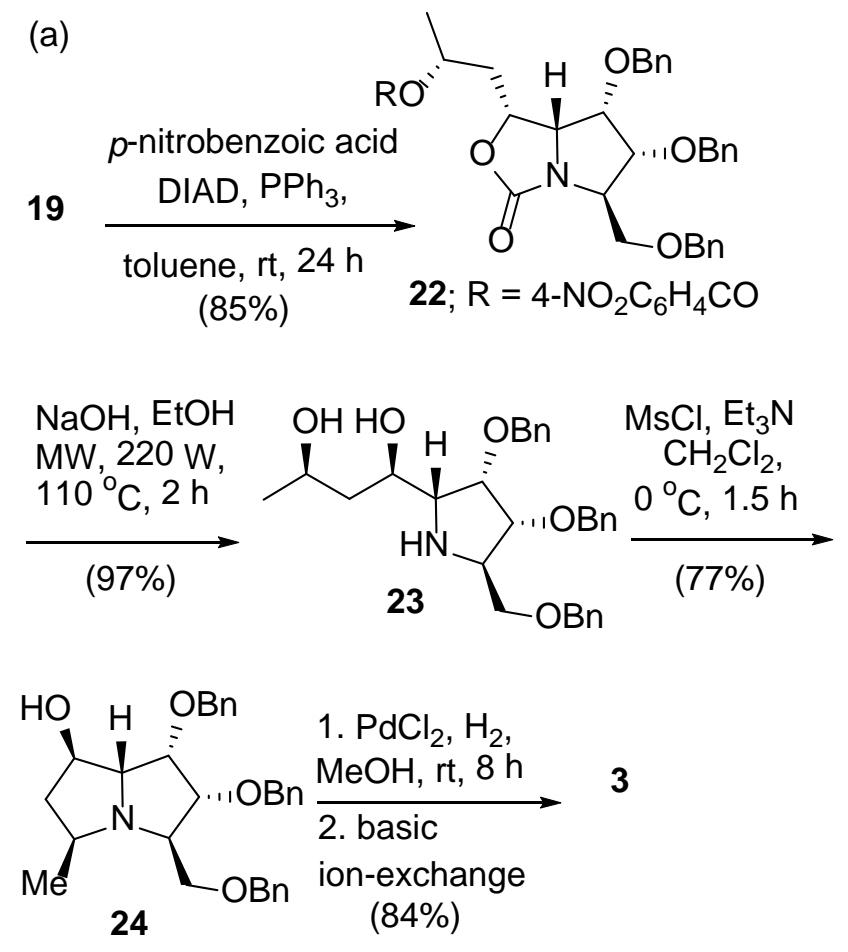

(b) oxalyl chloride,

24<smiles>CC1CC(=O)[C@@H]2[C@@H](Cc3ccccc3)[C@H](OCc3ccccc3)[C@@H](COCc3ccccc3)N2C1C</smiles>

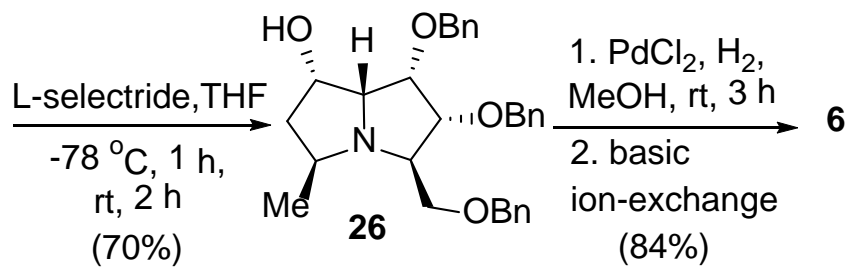

Unfortunately a sample of natural hyacinthacine $\mathrm{B}_{7}$ was no longer available from the authors for comparison with our synthetic product. ${ }^{11}$ However, as communicate earlier, a GC-MS analysis of the crude extract of the same Scilla socialis plants used in the original 
isolation paper showed no hyacinthacine corresponding to the retention time of $10.71 \mathrm{~min}$ for the tetra-TMS derivative of 3 (base ion at $388 \mathrm{amu}(100 \%)$ ) while four hyacinthacines in the $S$. socialis extract showed the same fragmentation pattern suggesting they were epimers of $3 .^{11}$ This analysis strongly suggested that $\mathbf{3}$ does not occur in that plant although epimers of $\mathbf{3}$ clearly do.

This information, and the differences in NOESY correlations between H-5 and H-7 in synthetic 3 and natural hyacinthacine $\mathrm{B}_{7}$, suggested to us that the natural product might be 7-epi-hyacinthacine $B_{7}(\mathbf{6})$, since the other possible A-ring epimer, hyacinthacine $B_{5}$ (5), had already been reported as a natural product. ${ }^{3 \mathrm{c}}$ To examine this possibility compound $\mathbf{6}$ was prepared from the pyrrolizidine $\mathbf{2 4}$ according to Scheme 4 (b). Thus the unprotected secondary alcohol in pyrrolizidine $\mathbf{2 4}$ was oxidized under Swern oxidation conditions $^{21}$ to give the ketone $\mathbf{2 5}$ in $63 \%$ yield. A diastereoselective reduction of this ketone with L-selectride from the less hindered convex face ( $\beta$-face) of the pyrrolizidine structure gave the alcohol 26, which was epimeric at C-7 with its precursor 24 . Debenzylation of 26 over $\mathrm{PdCl}_{2} / \mathrm{H}_{2}{ }^{17}$ gave 7-epi-hyacinthacine $\mathrm{B}_{7}(\mathbf{6})$ in $84 \%$ yield after purification and neutralization by basic ion-exchange chromatography (Scheme 4 (b)). While the ${ }^{1} \mathrm{H}$ and ${ }^{13} \mathrm{C}$ NMR spectroscopic data for this compound were a closer match to those of hyacinthacine $B_{7}$ than to those of synthetic $\mathbf{3}$, they were nonetheless not identical (see SI).

\section{Synthesis of hyacinthacines $B_{4}$ and $B_{5}$ and 7a-epi-hyacinthacine $B_{3}$}

While the above synthetic strategies readily provided the three desired target molecules, our synthesis of hyacinthacine $\mathrm{B}_{5}$ (5) did not proceeded as efficiently as planned. Our 
plan was to oxidize the secondary alcohol of $\mathbf{2 1}$ to the corresponding C-7 ketone and then convert this to the C-7 $\alpha$-carbinol $\mathbf{2 8}$ by a diastereoselective reduction with L-selectride using the conditions we had successfully employed in Scheme 4 (b). Compound 28 would then be de-O-benzylated to give hyacinthacine $\mathrm{B}_{5}(5)$. Surprizingly, the Swern oxidation of alcohol $\mathbf{2 1}$ gave the unexpected lactam-carboxylic acid $\mathbf{2 7}$ as the major oxidation product along with an inseparable mixture that comprised three other products from ${ }^{1} \mathrm{H}$ NMR analysis (Scheme 5 (a)). MS analysis of this mixture indicated that one of the components of this mixture might have been the desired ketone. The yield of $\mathbf{2 7}$ was $16 \%$ when the reaction mixture was held at $-78{ }^{\circ} \mathrm{C}$ for $1 \mathrm{~h}$ and $38 \%$ when the oxidation mixture was treated with $\mathrm{Et}_{3} \mathrm{~N}$ at $-78{ }^{\circ} \mathrm{C}$ and then warmed to rt for $1 \mathrm{~h}$. When the crude oxidation product mixture from the former oxidation reaction conditions $\left(-78{ }^{\circ} \mathrm{C}\right.$ for $1 \mathrm{~h}$ ) was treated with L-selectride, and then separated by column chromatography, four new compounds could be isolated, all in low yields, and identified. One product was the lactam-alcohol 31 (8\% yield), while the diastereomeric alcohols 28 (7\%), and 30 (4\%) and the ketone 29 (7\%) comprised the other three products (Scheme 5 (b)). The configurations of the products $\mathbf{2 8 ,} 29$ and $\mathbf{3 0}$ were determined from NOESY NMR experiments and their structures were further supported by their conversions to, hyacinthacine $\mathrm{B}_{5}(5)$ via hydrogenolysis, hyacinthacine $\mathrm{B}_{4}(4)$ via a diastereoselective Lselectride reduction to alcohol $\mathbf{3 2}$ and then hydrogenolysis, and 7a-epi-hyacinthacine $\mathrm{B}_{3}$ 33 via hydrogenolysis, respectively (Scheme 5 (c)). The ${ }^{1} \mathrm{H}$ and ${ }^{13} \mathrm{C}$ NMR spectroscopic data of synthetic compounds $\mathbf{4}$ and $\mathbf{5}$ matched very closely to those reported for these individual natural products, respectively (see SI). ${ }^{3 \mathrm{c}}$ The configurations assigned to these synthetic compounds were confirmed by NOESY NMR studies (see SI). The optical 
rotation of $\mathbf{5}\left([\alpha]_{D}^{25}-21.6^{\circ}, c 0.08, \mathrm{H}_{2} \mathrm{O}\right)$ matched well with that of natural hyacinthacine $\mathrm{B}_{5}\left([\alpha]_{D}-25.4^{\circ}, c 0.26, \mathrm{H}_{2} \mathrm{O}\right)^{3 \mathrm{C}}$ as did that of $4\left([\alpha]_{D}^{25}-7.7^{\circ}, c 0.18, \mathrm{H}_{2} \mathrm{O}\right)$ and natural hyacinthacine $\mathrm{B}_{4}\left([\alpha]_{D}-6.7^{\circ}, c 1.19, \mathrm{H}_{2} \mathrm{O}\right){ }^{3 \mathrm{c}}$ Thus these syntheses confirm the proposed structures and absolute configurations of hyacinthacines $\mathrm{B}_{4}$ and $\mathrm{B}_{5}$. 
Scheme 5. Synthesis of hyacinthacine $\mathrm{B}_{4} 4$, hyacinthacine $\mathrm{B}_{5} 5$, and 7a-epi-

hyancinthacine $B_{3} 33$

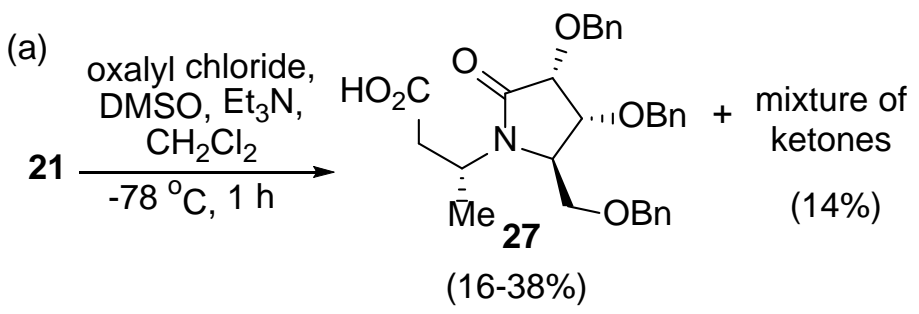

(b)
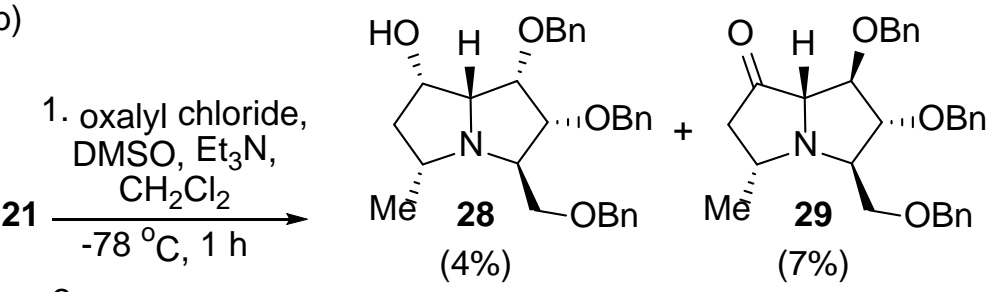

2. L-selectride, THF, $-78^{\circ} \mathrm{C}, 1 \mathrm{~h}$; $\mathrm{rt}, 2 \mathrm{~h}$

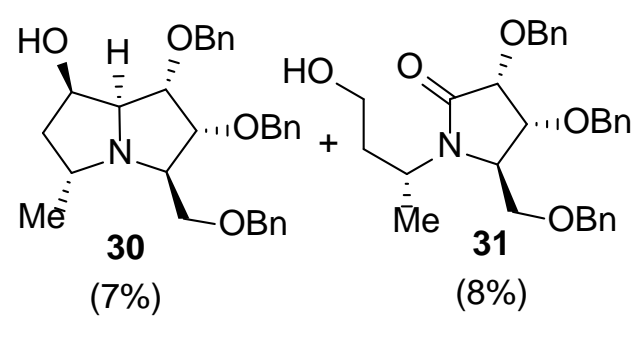
(c) 1. $\mathrm{PdCl}_{2}, \mathrm{H}_{2}$,
$28 \underset{\text { 2. basic }}{\stackrel{\mathrm{MeOH}, \mathrm{rt}, 3 \mathrm{~h}}{\longrightarrow}} 5$
ion-exchange
(21\%)

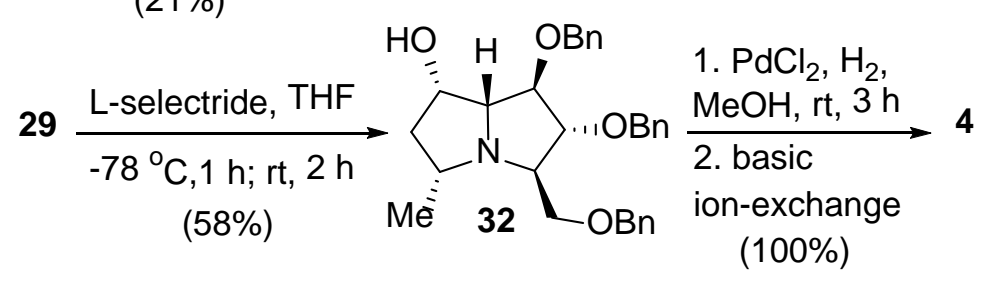
1. $\mathrm{PdCl}_{2}, \mathrm{H}_{2}$,
$30 \underset{\text { 2. basic }}{\stackrel{\mathrm{MeOH}, \mathrm{rt}, 3 \mathrm{~h}}{\longrightarrow}}$
ion-exchange
(100\%)

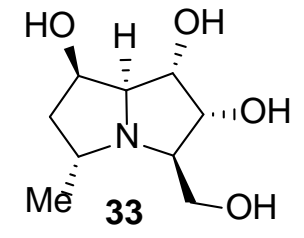


A possible mechanistic scheme for the formation of the B-ring fragmented products $\mathbf{2 7}$ and $\mathbf{3 1}$ is outlined in Scheme 6. This mechanism is also consistent with the finding that 27 was inert to reduction when treated with an excess amount of L-selectride under the reaction conditions indicated in Scheme 5 (b). Reaction of 21, via its tertiary nitrogen atom, with the dimethylchlorosulfonium species $\left(\mathrm{Me}_{2} \mathrm{SCl}^{+}\right)^{21}$ would lead to the $\mathrm{N}$ sulfonium intermediate $\mathbf{A}$ which upon base assisted fragmentation could give rise to the iminum ion B (Scheme 6). DMSO assisted cyclization of $\mathbf{B}$ could lead to the bicyclic intermediate $\mathbf{C}$ which upon base promoted elimination-fragmentation would give the resonance stabilized cation intermediate $\mathbf{D}$. Quenching of the reaction mixture with water could give rise to the aminal $\mathbf{F}$ which could give the lactam $\mathbf{2 7}$ upon chromatography on silica gel. Reduction of $\mathbf{F}$ with an excess amount of L-selectride could give alcohol $\mathbf{3 1}$ (Scheme 6).

The alcohol 28, however, clearly arises from reduction of the expected and desired C-7 ketone 34, that could not be isolated in pure form, while alcohol $\mathbf{3 0}$ seems to have formed from reduction of ketone 35, the C-7a epimer of ketone 34 (Scheme 7 (a)). Such an epimerization process would seem likely as it would relieve unfavorable steric interactions between the substituents at C-1, C-2 and C-5 on the more crowded concave face of 34 (Scheme 7 (a)). In the C-7a epimeric ketone 35 these substituents are now on the less crowded convex face of the molecule. The isolation of ketone 29 in Scheme 5 (b), suggests that this compound was protected from reduction with L-selectride by formation of its corresponding enolate anion. A tentative mechanism to support such an enolate intermediate, which also accounts for the inversion of configuration at C-1, is shown in Scheme 7 (b). This mechanism involves formation of the enone $\mathbf{G}$ which upon 1,4- 
reduction by L-selectride, with addition of hydride at C-1 from the stereoelectronically favored pseudo-axial direction, would give an enolate anion which upon quenching with water and protonation at C-7a, from the stereoelectronically favored pseudo-axial direction, would give 29 (Scheme 7 (b)).

Scheme 6. Proposed mechanism for the formation of ring-fragmented products 27 and 31.
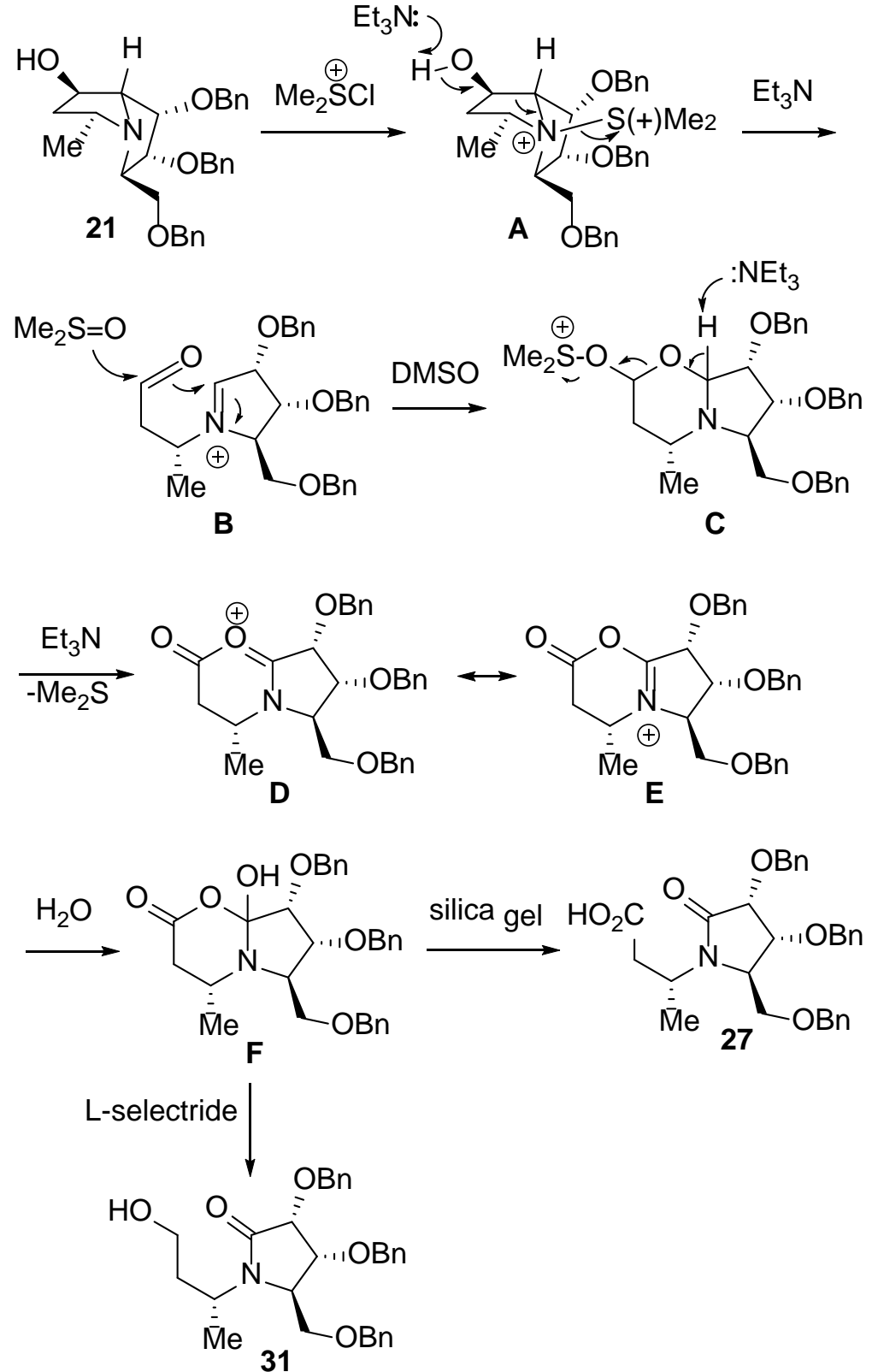
Scheme 7. Proposed intermediates and mechanisms.

(a)
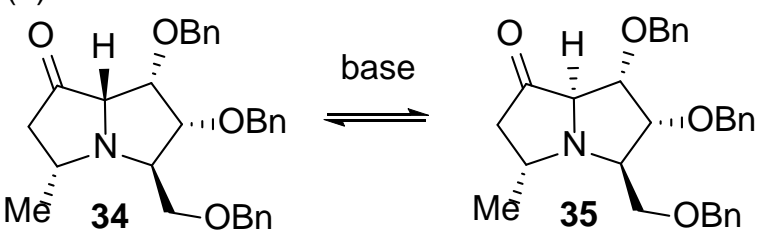

(b)
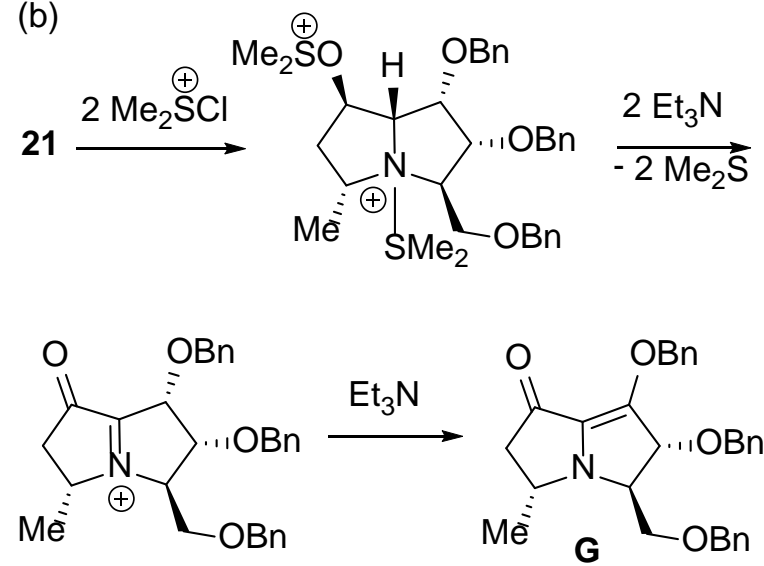

1. L-selectride 2. $\mathrm{H}_{2} \mathrm{O}$

The relatively more straight forward oxidation of alcohol $\mathbf{2 4}$ to its desired ketone $\mathbf{2 5}$ (Scheme 4 (b)) is likely a consequence of the C-5 $\beta$-methyl substituent which would sterically hinder the formation of an intermediate analogous to $\mathbf{A}$ in Scheme 6 (Scheme 8).

\section{Scheme 8.}

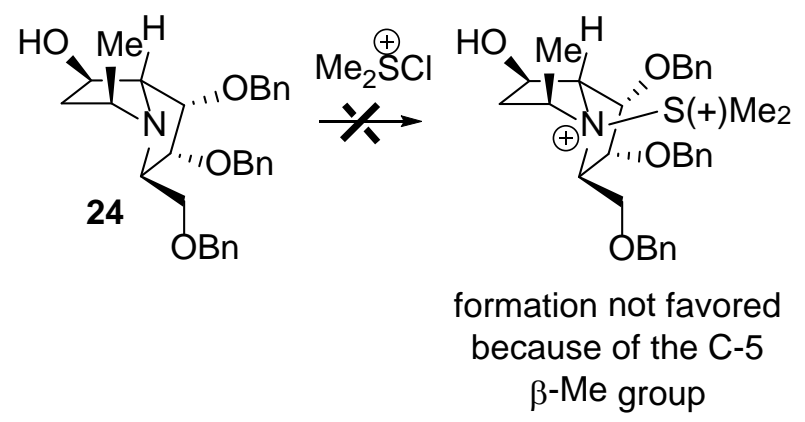


Attempts to prepare the C-7 inverted alcohol $\mathbf{2 8}$ more efficiently by $\mathrm{S}_{\mathrm{N}} 2$ inversion reactions of the alcohol 21 were also unsuccessful (Scheme 9). The Mitsunobu reaction of 21 gave the p-nitrobenzoate 36 in very poor yield (8\%) and with retention of configuration at C-7. The $O$-mesylate derivative 37 of 21 gave a more respectable yield of the benzoate 38, upon treatment with $\mathrm{CsOBz}^{22}$ however again with retention of configuration at C-7. The configuration of esters $\mathbf{3 6}$ and $\mathbf{3 8}$ were confirmed from there base hydrolysis back to the alcohol 21. While the Mitsunobu reaction of hindered alcohols can proceed with retention of configuration by direct $O$-acylation of the alcohol by $\left[\mathrm{ArCO}_{2} \mathrm{PPh}_{3}\right]^{+}$, 23 we suspect that the aziridinium ion intermediate $\mathbf{H}^{24}$ is formed in these reactions leading to C-7 esters with overall retention of configuration (Scheme 9). 
Scheme 9. Attempts to invert the configuration at C-7 of alcohol 21.

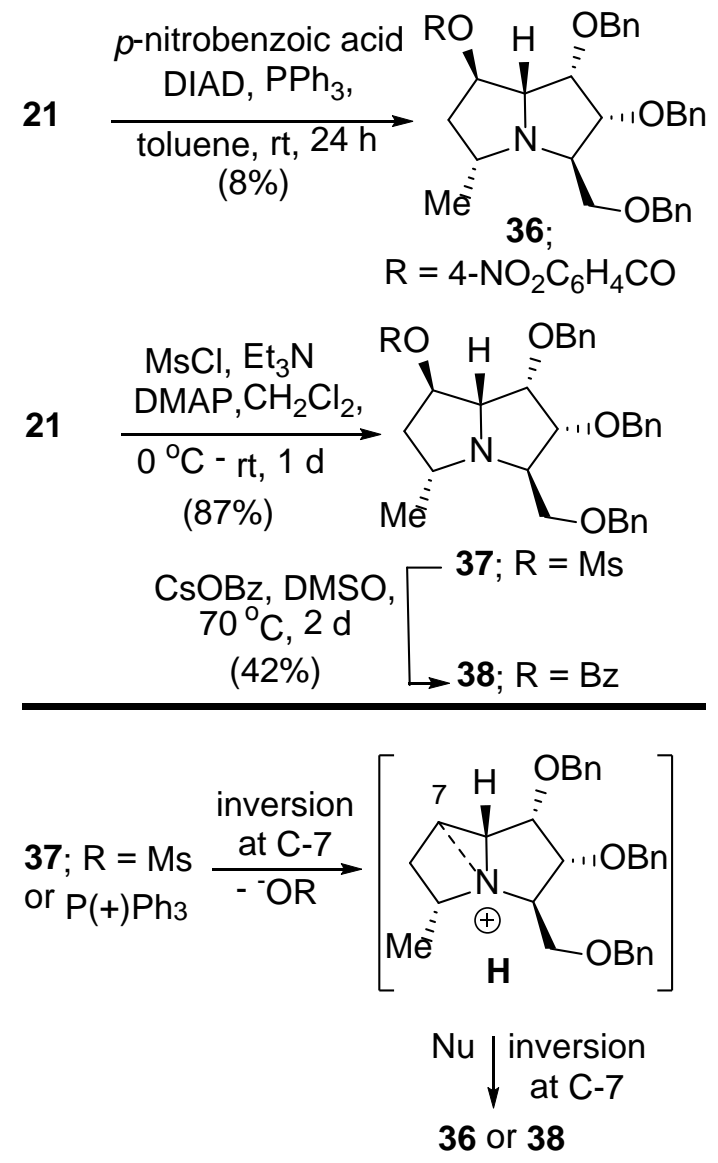

A comparison of the ${ }^{13} \mathrm{C}$ NMR chemical shifts (rounded up to the nearest whole integer) of synthetic compounds 2, 3, 5 and $\mathbf{6}$ (all with the same configurations at C-1 - C-3 and C-7a) and those of natural hyacinthacine $B_{7}$ is shown in Figure 3. Compounds 2 and $\mathbf{5}$, with an $\alpha$-methyl group at C-5, have nearly the same ${ }^{13} \mathrm{C}$ NMR chemical shifts for $\mathrm{C}-3$, C-5, C-8 and C-9. This is also true for compounds $\mathbf{3}$ and $\mathbf{6}$, having a $\beta$-methyl group at C5. However, these particular chemical shifts observed for compounds $\mathbf{3}$ and $\mathbf{6}$ are significantly downfield of those of their corresponding carbons seen in the ${ }^{13} \mathrm{C}$ NMR spectra of compounds 2 and 5, except for the chemical shift of C-8 which is insensitive to the configuration at C-5. Interestingly, the ${ }^{13} \mathrm{C}$ NMR chemical shifts for C-3, C-5, C-8 and $\mathrm{C}-9$ of hyacinthacine $\mathrm{B}_{4} \mathbf{4}$, the C-1 epimer of $\mathbf{5}$, and 5 are also nearly the same. 
Compounds 2 and 3, with a $\beta$-hydroxy group at C-7, have nearly the same ${ }^{13} \mathrm{C}$ NMR chemical shifts for C-1, C-7 and C-7a. This is also observed for compounds $\mathbf{5}$ and $\mathbf{6}$, having an $\alpha$-hydroxy group at C-7. In compounds 2 and 3, C-7a resonates at $\delta$ 75-76, downfield of the signals for C-1 and C-7 ( $\delta 71-74)$, while in the ${ }^{13} \mathrm{C}$ NMR spectra of compounds 5 and 6, the reverse trend is observed (C-7a, $\delta$ 70-71 and C-1 and C-7 ( $\delta$ 75-76).

In light of this analysis, an examination of the ${ }^{13} \mathrm{C}$ NMR chemical shifts for C-3, C-5, C-8 and C-9 of natural hyacinthacine $B_{7}$ (Figure 2), would indicate the $\alpha$-configuration of the C-5 methyl group rather than the assigned $\beta$-configuration. Further, if one assumes that the chemical shifts of C-1 (reported as $\delta 77.9$ ) and C-2 (reported as $\delta 74.9$ ) have been missassigned in natural hyacinthacine $\mathrm{B}_{7}$ [these chemical shifts are not consistent with those of the other hyacinthacine alkaloids (in compounds $\mathbf{2}-\mathbf{6}$, the ${ }^{13} \mathrm{C}$ NMR chemical shift of C-2 is always downfield of that of C-1, see SI)] then this compound should have the $\alpha$-configuration at $\mathrm{C}-1$ and not the initially assigned $\beta$-configuration. This analysis suggests that natural hyacinthacine $B_{7}$ is actually hyacinthacine $B_{5} 5$. Further, analysis of Table 1 indicates a close match between their ${ }^{13} \mathrm{C}$ NMR chemical shifts. A comparison of the ${ }^{1} \mathrm{H}$ NMR chemical shifts and coupling constants for these two alkaloids shows close agreement for the protons $\mathrm{H}-1, \mathrm{H}-2, \mathrm{H}-6 \beta, \mathrm{H}-7, \mathrm{H}-8$ and $\mathrm{H}-9$ (Table 2) and a consistent difference of $c a 0.2$ ppm for the protons $\mathrm{H}-3, \mathrm{H}-5, \mathrm{H}-6 \alpha, \mathrm{H}-7 \mathrm{a}$ and $\mathrm{H}-8$ '. Considering that the chemical shifts of these types of compounds are sensitive to $\mathrm{pH}$ and concentration effects ${ }^{4}$ these NMR data would seem to be a good match, and support our proposal that they are the same compound (hyacinthacine $\mathrm{B}_{5}$ ). Their specific rotations however, are of the same sign but differ significantly in magnitude (hyacinthacine $\mathrm{B}_{5}:[\alpha]_{D}-25.4$ (c 0.26, 
$\left.\mathrm{H}_{2} \mathrm{O}\right)^{3 \mathrm{c}}$; natural hyacinthacine $\left.\mathrm{B}_{7}:[\alpha]_{D}-4.4\left(c 0.20, \mathrm{H}_{2} \mathrm{O}\right)^{3 \mathrm{~b}}\right)$. However, without having authentic samples of these two natural products in hand it is impossible to either verify or disprove our proposal and thus unequivocally demonstrate the correct structure of natural hyacinthacine $\mathrm{B}_{7}$.
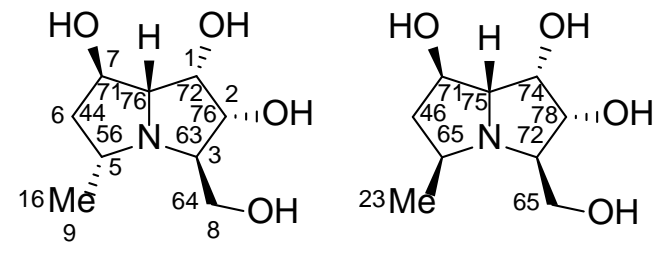

hyacinthacine $B_{3}$

2

$$
\text { synthetic }
$$

3
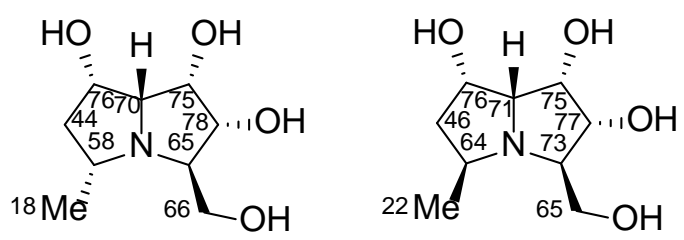

hyacinthacine $\mathrm{B}_{5} \quad$ 7-epi-hyacinthacine $\mathrm{B}_{7}$

5

6

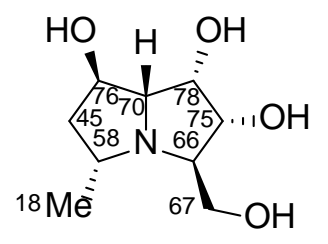

natural hyacinthacine $B_{7}$

Figure $2 .{ }^{13} \mathrm{C}$ NMR chemical shifts (rounded to the nearest whole integer) of compounds 2, 3, 4, 5, 6 and natural hyacinthacine $B_{7}$. 
Table 1. Comparison of literature ${ }^{13} \mathrm{C}$ NMR chemical shifts $\left(125 \mathrm{MHz}, \mathrm{D}_{2} \mathrm{O}\right)$ of natural hyacinthacine $\mathbf{B}_{7}{ }^{3 \mathrm{~d}}$ and natural hyacinthacine $\mathbf{B}_{5}{ }^{3 \mathrm{c}}$

$\begin{array}{ccc}\text { carbon } & \begin{array}{c}\text { natural } \\ \text { hyacinthacine } \mathrm{B}_{7}{ }^{3 \mathrm{~d}}\end{array} & \begin{array}{c}\text { natural } \\ \text { hyacinthacine } \mathrm{B}_{5}{ }^{3 \mathrm{c}} \\ \delta_{\mathrm{C}}(\mathrm{ppm})\end{array} \\ 1 & 77.9 & 74.8 \\ 2 & 74.9 & 76.9 \\ 3 & 66.2 & 65.5 \\ 5 & 57.7 & 58.5 \\ 6 & 45.2 & 43.9 \\ 7 & 76.5 & 75.0 \\ 7 \mathrm{a} & 69.9 & 70.1 \\ 8 & 66.8 & 64.7 \\ 9 & 18.4 & 17.9\end{array}$

Table 2. Comparison of literature ${ }^{1} \mathrm{H}$ NMR chemical shifts $\left(500 \mathrm{MHz}, \mathrm{D}_{2} \mathrm{O}\right)$ of natural hyacinthacine $\mathbf{B}_{7}{ }^{3 \mathrm{~d}}$ and natural hyacinthacine $\mathbf{B}_{5}{ }^{3 \mathrm{c}}$

\begin{tabular}{cclcl} 
& \multicolumn{2}{c}{ natural hyacinthacine $\mathrm{B}_{7}{ }^{3 \mathrm{~d}}$} & \multicolumn{2}{c}{ natural hyacinthacine $\mathrm{B}_{5}{ }^{3 \mathrm{c}}$} \\
proton & $\delta_{\mathrm{H}}(\mathrm{ppm})$ & \multicolumn{1}{c}{ Mult., $J(\mathrm{~Hz})$} & $\delta_{\mathrm{H}}(\mathrm{ppm})$ & \multicolumn{1}{c}{ Mult., $J(\mathrm{~Hz})$} \\
\hline 1 & 4.35 & $\mathrm{t}(4.4)$ & 4.37 & $\mathrm{dd}(4.4,4.2)$ \\
2 & 3.97 & $\mathrm{dd}(7.6,4.4)$ & 4.08 & $\mathrm{dd}(8.0,4.2)$ \\
3 & 3.29 & $\mathrm{ddd}(7.6,5.5,3.5)$ & 3.48 & $\mathrm{ddd}(5.1,4.6,4.2)$ \\
5 & 3.22 & $\mathrm{~m}$ & 3.44 & $\mathrm{~m}$ \\
$6 \alpha$ & 1.68 & $\mathrm{~m}$ & 1.86 & $\mathrm{ddd}(12.5,10.0,8.0)$ \\
$6 \beta$ & 2.16 & $\mathrm{~m}$ & 2.22 & $\mathrm{ddd}(12.5,6.4,6.0)$ \\
7 & 4.50 & $\mathrm{~m}$ & 4.55 & $\mathrm{ddd}(8.0,7.6,6.4)$ \\
$7 \mathrm{a}$ & 3.45 & $\mathrm{dd}(7.6,4.4)$ & 3.66 & $\mathrm{dd}(7.6,4.4)$ \\
8 & 3.57 & $\mathrm{dd}(11.5,3.5)$ & 3.70 & $\mathrm{dd}(12.0,5.1)$ \\
$8^{\prime}$ & 3.63 & $\mathrm{dd}(11.5,5.5)$ & 3.73 & $\mathrm{dd}(12.0,4.6)$ \\
9 & 1.25 & $\mathrm{~d}(7.0)$ & 1.32 & $\mathrm{~d}(7.0)$
\end{tabular}




\section{CONCLUSIONS}

In conclusion, the total synthesis of hyacinthacines $B_{3}, B_{4}$, and $B_{5}$, purported hyacinthacine $\mathrm{B}_{7}$, 7-epi- hyacinthacine $\mathrm{B}_{7}$, and 7a-epi- hyacinthacine $\mathrm{B}_{3}$, from a common anti-1,2-amino alcohol precursor (7), has been achieved. These syntheses have confirmed that the proposed structures and absolute configurations of hyacinthacines $B_{3}, B_{4}$, and $B_{5}$ are correct and disclosed that the proposed structure of natural hyacinthacine $\mathrm{B}_{7}$ was incorrect. Our synthetic and spectroscopic studies suggest that the natural hyacinthacines $\mathrm{B}_{5}$ and $\mathrm{B}_{7}$ are the same compound; however without access to authentic samples this cannot be unequivocally proven.

\section{EXPERIMENTAL SECTION}

General Methods. Flash column chromatography packed with Merck Kieselgel 60 $\mathrm{PF}_{254}$ was used for purification. A single quadrupole mass spectrometer was used for obtaining the LRESIMS. Quadrupole time-of-flight mass spectrometers were used for acquiring HRESIMS and HRASAPMS. IR spectra were run on neat samples. ${ }^{1} \mathrm{H}$ (500 or $300 \mathrm{MHz}$ ) and ${ }^{13} \mathrm{C}$ NMR (125 or $75 \mathrm{MHz}$ ) NMR spectra were recorded in deuterochloroform $\left(\mathrm{CDCl}_{3}\right)$, deuterium oxide $\left(\mathrm{D}_{2} \mathrm{O}\right)$ or deuterated methanol- $\mathrm{d}_{4}\left(\mathrm{CD}_{3} \mathrm{OD}\right)$ solution. All signals which were recorded in $\mathrm{CDCl}_{3}$ were relative to the tetramethylsilane (TMS) signal and the $\mathrm{CDCl}_{3}$ signal, referenced at $0.00 \mathrm{ppm}$ (for ${ }^{1} \mathrm{H} \mathrm{NMR}$ ) and $77.16 \mathrm{ppm}$, (for ${ }^{13} \mathrm{C}$ NMR), respectively. All signals which were recorded in $\mathrm{CD}_{3} \mathrm{OD}$ were relative to the $\mathrm{CD}_{2} \mathrm{HOD}$ signal for ${ }^{1} \mathrm{H}$ NMR and the $\mathrm{CD}_{3} \mathrm{OD}$ for ${ }^{13} \mathrm{C}$ NMR, referenced at $3.31 \mathrm{ppm}$ and $49.00 \mathrm{ppm}$, respectively. All signals which were recorded in $\mathrm{D}_{2} \mathrm{O}$ were relative to the $\mathrm{D}_{2} \mathrm{O}$ signal for ${ }^{1} \mathrm{H}$ NMR, referenced at $4.49 \mathrm{ppm}$. For ${ }^{13} \mathrm{C}$ NMR spectra in $\mathrm{D}_{2} \mathrm{O}$ the referencing of peaks is relative to internal $\mathrm{MeOH}$ (49.50 ppm). In some cases the ${ }^{13} \mathrm{C}$ 
NMR spectral data were referenced to sodium 3-(trimethylsilyl)propionate (TSP) at $\delta$ 2.19 in $\mathrm{D}_{2} \mathrm{O}$. In order to compare our ${ }^{13} \mathrm{C}$ NMR data recorded in $\mathrm{D}_{2} \mathrm{O}$ (and referenced to internal $\mathrm{MeOH}$ ) with those of the literature which were run in $\mathrm{D}_{2} \mathrm{O}$ and referenced to TSP at $\delta 0.00$ we have added $2.19 \mathrm{ppm}$ to our observed ${ }^{13} \mathrm{C}$ NMR chemical shifts in the ${ }^{13} \mathrm{C}$ NMR comparison tables (SI). NMR assignments were based upon gCOSY, APT, gHSQC, gHMBC and NOESY experiments. In some cases, ${ }^{13} \mathrm{C}$ NMR signals that were absent in the standard ${ }^{13} \mathrm{C}$ NMR spectrum were identified using gHSQC and gHMBC experiments. Petrol refers to the hydrocarbon fraction of bp. $40-60{ }^{\circ} \mathrm{C}$. are named using systematic nomenclature. The NMR assignments made to pyrrolizidine compounds are based on the numbering system of the hyacinthacine alkaloids and not the systematic name.

\section{Synthesis of hyacinthacine $B_{3}(2)$.}

(2R,4S)-4-(4-Methoxybenzyloxy)pentane-1,2-diol (13) A solution of 12 (2.58 g, 12.49 mmol) in tert-butanol $(20 \mathrm{~mL})$ was slowly added dropwise into a solution of potassium ferric cyanide (12.34 g, $37.48 \mathrm{mmol})$, potassium carbonate $(5.18 \mathrm{~g}, 37.48 \mathrm{mmol})$, methanesulfonamide (1.19 g, $12.49 \mathrm{mmol}$ ), potassium osmate dihydrate (55 mg, 0.150 mmol) and (DHQD) $)_{2}$ PYR $(0.110 \mathrm{~g}, 0.125 \mathrm{mmol})$ in $\mathrm{H}_{2} \mathrm{O}(40 \mathrm{~mL})$ which was cooled in an ice bath. The reaction mixture was stirred at $3-5{ }^{\circ} \mathrm{C}$ (in a cold room) for $2 \mathrm{~d}$. The reaction was quenched with sodium sulfite $(9.44 \mathrm{~g}, 74.94 \mathrm{mmol})$ and then allowed to warm to rt $\left(21{ }^{\circ} \mathrm{C}\right)$, stirred for $30 \mathrm{~min}$ and then extracted with EtOAc $(3 \times 100 \mathrm{~mL})$. The combined organic layers were dried $\left(\mathrm{MgSO}_{4}\right)$ and concentrated in vacuo. Purification by flash column chromatography (increasing polarity from 0:100 to 4:96 of $\mathrm{MeOH} / \mathrm{CH}_{2} \mathrm{Cl}_{2}$ ) gave the title compound as a colorless oil (2.736 g, $99 \%, \mathrm{dr}=4: 1) . R_{f} \quad 0.50(10: 90$ $\left.\mathrm{MeOH} / \mathrm{CH}_{2} \mathrm{Cl}_{2}\right) .[\alpha]_{D}^{25}-46.5$ (c 1.64, $\left.\mathrm{CHCl}_{3}\right)$. IR $v_{\max }\left(\mathrm{cm}^{-1}\right): 3396,2925,1614,1512$, 
1244, 1031, 818. $\delta_{\mathrm{H}}\left(500 \mathrm{MHz}, \mathrm{CDCl}_{3}\right)$ : (major diastereomer) $7.25(2 \mathrm{H}, \mathrm{d}, J=8.8 \mathrm{~Hz})$, $6.87(2 \mathrm{H}, \mathrm{d}, J=8.8 \mathrm{~Hz}), 4.54(1 \mathrm{H}, \mathrm{d}, J=11.2 \mathrm{~Hz}), 4.36(1 \mathrm{H}, \mathrm{d}, J=11.2 \mathrm{~Hz}), 3.96(1 \mathrm{H}, \mathrm{s}$ (br), H2), 3.87 - $3.82(1 \mathrm{H}, \mathrm{m}, \mathrm{H} 4), 3.78(3 \mathrm{H}, \mathrm{s}), 3.56\left(1 \mathrm{H}, \mathrm{dd}, J=10.8,9.8 \mathrm{~Hz}, \mathrm{H} 1_{\mathrm{A}}\right)$, $3.43\left(1 \mathrm{H}, \mathrm{dd}, J=9.8,7.3 \mathrm{~Hz}, \mathrm{H}_{\mathrm{B}}\right), 1.74-1.65\left(1 \mathrm{H}, \mathrm{m}, \mathrm{H} 3_{\mathrm{A}}\right), 1.55$ (1H, ddd, $J=10.7,7.8$, $\left.2.9 \mathrm{~Hz}, \mathrm{H} 3_{\mathrm{B}}\right), 1.24$ (3H, d, $\left.J=6.3 \mathrm{~Hz}, \mathrm{H} 5\right)$. (minor diastereomer, in part) 4.59 (1H, d, $J=$ $11.2 \mathrm{~Hz}), 4.34(1 \mathrm{H}, \mathrm{d}, J=11.2 \mathrm{~Hz}) . \delta_{\mathrm{C}}\left(125 \mathrm{MHz}, \mathrm{CDCl}_{3}\right)$ : (major diastereomer) 159.3 (ArC), 130.4 (ArC), 129.5 (2 x ArCH), 114.0 (2 x ArCH), 72.2 (C4), 70.3 ( $\left.\mathrm{OCH}_{2} \mathrm{PMP}\right)$, 69.3 (C2), 66.9 (C1), $55.3\left(\mathrm{OCH}_{3}\right), 39.3$ (C3), 19.5 (C5). (minor diastereomer, in part) 132.1 (ArC), 131.9 (ArC), 114.4 (ArCH), 71.9 (C4), 70.1 (OCH $\left.{ }_{2} \mathrm{PMP}\right), 66.7$ (C1), 33.9 (C3), 19.7 (C5). ESIMS m/z 263 (100\%) [M+Na] $]^{+}$. HRESIMS found 263.1258, calcd for $\mathrm{C}_{13} \mathrm{H}_{20} \mathrm{O}_{4} \mathrm{Na}, 263.1259[\mathrm{M}+\mathrm{Na}]^{+}$.

Oxidation of diol 13. A mixture of $\mathbf{1 3}$ (208 mg, 0.87 mmol), 2,2,6,6-tetramethyl-1piperidinyloxy free radical (TEMPO) (3 mg, $0.02 \mathrm{mmol}$ ), potassium bromide (113 mg, $0.95 \mathrm{mmol})$, anhydrous $\mathrm{CH}_{2} \mathrm{Cl}_{2}(9.5 \mathrm{~mL})$ and saturated aq $\mathrm{NaHCO}_{3}$ solution $(3.8 \mathrm{~mL})$ was cool to $0{ }^{\circ} \mathrm{C}$. Commercial sodium hypochlorite solution $(0.4 \mathrm{M}, 3.0 \mathrm{~mL}, 1.21 \mathrm{mmol})$ was added slowly dropwise and stirred at $0{ }^{\circ} \mathrm{C}$ for $30 \mathrm{~min}$. Saturated aq sodium thiosulfate solution $(8.6 \mathrm{~mL})$ was added at $0{ }^{\circ} \mathrm{C}$. The reaction mixture was extracted with EtOAc (3 x $100 \mathrm{~mL}$ ), dried $\left(\mathrm{MgSO}_{4}\right)$, and concentrated in vacuo to give a white solid which was used in the subsequent Petasis reaction without further puricication. (3S,4R,6S,E)-3-((S)-1-(Benzyloxy)but-3-en-2-ylamino)-6-(4-methoxybenzyloxy)-4methoxy-1-phenylhept-1-en-4-ol (7). A solution of $\mathbf{1 0}$ (183 mg, $1.03 \mathrm{mmol})$ in anhydrous $\mathrm{CH}_{2} \mathrm{Cl}_{2}(0.5 \mathrm{~mL})$ was added to a solution of the above crude oxidation product and (E)-2phenylvinylboronic acid (153 $\mathrm{mg}, 1.03 \mathrm{mmol})$ in $1,1,1,3,3,3-$ 
hexafluoroisopropanol/ $\mathrm{CH}_{2} \mathrm{Cl}_{2}(1: 9,3.5 \mathrm{~mL})$ under a nitrogen atmosphere. The reaction mixture was stirred at $\mathrm{rt}\left(32{ }^{\circ} \mathrm{C}\right)$ for $2 \mathrm{~d}$, diluted with EtOAc $(25 \mathrm{~mL})$ and washed with 0.5 $\mathrm{M} \mathrm{NaOH}$ solution (3 x $25 \mathrm{~mL})$. The organic layer was dried $\left(\mathrm{MgSO}_{4}\right)$ and concentrated in vacuo to give a dark brown oil. Purification by flash column chromatography (0:100 to 40:60 EtOAc/ $\mathrm{CH}_{2} \mathrm{Cl}_{2}$ as eluent) gave the title compound (314 mg, $73 \%$, 2 steps) as a brown oil. $R_{f} 0.45\left(5: 95 \mathrm{MeOH} / \mathrm{CH}_{2} \mathrm{Cl}_{2}\right) \cdot[\alpha]_{D}^{25}+11.9\left(c 0.56, \mathrm{CHCl}_{3}\right) . \mathrm{IR} v_{\max }\left(\mathrm{cm}^{-1}\right)$ : 3438, 3066, 3027, 2905, 2860, 1648, 1611, 1511, 1452, 1245, 1076, 1035, 975, 925, 818, 746, 696. $\delta_{\mathrm{H}}\left(500 \mathrm{MHz}, \mathrm{CDCl}_{3}\right): 7.36-7.19(12 \mathrm{H}, \mathrm{m}), 6.8(2 \mathrm{H}, \mathrm{d}, J=8.3, \mathrm{~Hz}), 6.43(1 \mathrm{H}$, d, $J=16.1 \mathrm{~Hz}, \mathrm{H1}), 6.08$ (1H, dd, $J=16.1,8.3 \mathrm{~Hz}, \mathrm{H} 2), 5.63$ - 5.56 (1H, m, H2'), 5.21 (1H, d, $J=17.1 \mathrm{~Hz}, \mathrm{H3}^{\prime}$ trans), 5.17 (1H, d, $J=10.2 \mathrm{~Hz}, \mathrm{H3}{ }^{\prime}$ cis), 4.51 (1H, d, , $J=11.2$ Hz), 4.49 (2H, s), 4.37 (1H, d, $J=11.2 \mathrm{~Hz}), 4.02(1 \mathrm{H}, \mathrm{s}(\mathrm{br}), \mathrm{H} 4), 3.84-3.81(1 \mathrm{H}, \mathrm{m}$, H6), 3.75 (3H, s), 3.49 - 3.42 (3H, m), 3.24 (1H, dd, $J=8.3,3.4 \mathrm{~Hz}, \mathrm{H} 3$ ), 1.58 (2H, dd, $J$ = 6.4, $5.4 \mathrm{~Hz}, \mathrm{H} 5), 1.21(3 \mathrm{H}, \mathrm{d}, J=6.4 \mathrm{~Hz}, \mathrm{H} 7) . \delta_{\mathrm{C}}\left(125 \mathrm{MHz}, \mathrm{CDCl}_{3}\right): 159.1(\mathrm{ArC})$, 138.2 (ArC), 138.0 (CH=), 136.9 (ArC), 132.8 (C1), 130.9 (ArC), 129.3 (2 x ArCH), 128.5 (2 x $\mathrm{ArCH}), 128.4$ (2 x $\mathrm{ArCH}), 128.1$ (C2), 127.7 (2 x $\mathrm{ArCH}), 127.5$ (2 x $\mathrm{ArCH})$, $126.4(2 \times \mathrm{ArCH}), 117.9\left(=\mathrm{CH}_{2}\right), 113.8(2 \times \mathrm{ArCH}), 73.4\left(\mathrm{CH}_{2}\right), 73.0\left(\mathrm{OCH}_{2} \mathrm{Ph}\right), 72.2$ (C6), 70.4 (OCH $2 \mathrm{PMP}), 70.4$ (C4), 62.3 (C3), $58.0(\mathrm{CH}), 55.3\left(\mathrm{OCH}_{3}\right), 40.2$ (C5), 19.8 (C7). ESIMS m/z $502(100 \%)[\mathrm{M}+\mathrm{H}]^{+}$, HRESIMS found 502.2954, calc for $\mathrm{C}_{32} \mathrm{H}_{40} \mathrm{NO}_{4}$, $502.2957[\mathrm{M}+\mathrm{H}]^{+}$. (4S,5R)-3-((S)-1-(Benzyloxy)but-3-en-2-yl)-5-((S)-2-(4-methoxybenzyloxy)propyl)-4styryloxazolidin-2-one (15). Small scale reaction: Triphosgene (6 mg, $0.020 \mathrm{mmol})$ was slowly added to the solution of the 1,2-amino alcohol 7 (20 mg, $0.040 \mathrm{mmol})$ and triethylamine $(11 \mu \mathrm{L}, 0.080 \mathrm{mmol})$ in anhydrous $\mathrm{CH}_{2} \mathrm{Cl}_{2}(3 \mathrm{~mL})$ at $0{ }^{\circ} \mathrm{C}$ under a nitrogen 
atmosphere. After stirring for 15 min the reaction mixture was allowed to warm to rt, stirred for $18 \mathrm{~h}$ and then concentrated in vacuo to give a yellow solid. Purification by flash column chromatography (increasing polarity from 0:100 to 1:99 of $\mathrm{MeOH} / \mathrm{CH}_{2} \mathrm{Cl}_{2}$ as eluent) gave the title compound (17 $\mathrm{mg}, 81 \%)$ as a colorless oil. Larger scale reaction: Using triphosgene (0.186 g, $0.625 \mathrm{mmol}), 7$ (625 mg, $1.25 \mathrm{mmol}$ ) and triethylamine (697 $\mu \mathrm{L}, 4.99 \mathrm{mmol})$ the title compound $(0.435 \mathrm{~g}, 66 \%)$ was obtained as a colorless oil. $R_{f}$ $0.66\left(2: 98 \mathrm{MeOH} / \mathrm{CH}_{2} \mathrm{Cl}_{2}\right) \cdot[\alpha]_{D}^{25}+20.9\left(c\right.$ 0.05, $\left.\mathrm{CHCl}_{3}\right) . \mathrm{IR} v_{\max }\left(\mathrm{cm}^{-1}\right): 3028,2966$, 2929, 2865, 1743, 1612, 1512, 1453, 1402, 1246, 1072, 1033, 977, 932, 820, 753, 695, 608. $\delta_{\mathrm{H}}\left(500 \mathrm{MHz}, \mathrm{CDCl}_{3}\right): 7.33-7.23(12 \mathrm{H}, \mathrm{m}), 6.86(2 \mathrm{H}, \mathrm{d}, J=8.3 \mathrm{~Hz}), 6.30(1 \mathrm{H}, \mathrm{d}, J$ = $15.9 \mathrm{~Hz}), 6.00(1 \mathrm{H}, \mathrm{dd}, J=15.9,9.8 \mathrm{~Hz}), 5.86-5.78(1 \mathrm{H}, \mathrm{m}), 5.25(1 \mathrm{H}, \mathrm{d}, J=16.1 \mathrm{~Hz})$, $5.18(1 \mathrm{H}, \mathrm{d}, J=10.2 \mathrm{~Hz}), 4.86(1 \mathrm{H}, \mathrm{ddd}, J=10.3,8.8,1.5 \mathrm{~Hz}), 4.61(1 \mathrm{H}, \mathrm{d}, J=11.7 \mathrm{~Hz})$, $4.52(1 \mathrm{H}, \mathrm{d}, J=10.7 \mathrm{~Hz}), 4.47(1 \mathrm{H}, \mathrm{d}, J=11.7 \mathrm{~Hz}), 4.37-4.40(2 \mathrm{H}, \mathrm{m}), 4.34(1 \mathrm{H}, \mathrm{d}, J=$ $10.7 \mathrm{~Hz}), 3.89$ (1H, dd, $J=10.0,9.3 \mathrm{~Hz}), 3.83$ - $3.81(1 \mathrm{H}, \mathrm{m}), 3.79$ (3H, s), 3.61 (1H, dd, $J=10.0,4.9 \mathrm{~Hz}), 1.70(1 \mathrm{H}, \mathrm{td}, J=11.9,2.0 \mathrm{~Hz}), 1.60(1 \mathrm{H}, \mathrm{dd}, J=11.9,11.2 \mathrm{~Hz}), 1.19$ (3H, d, $J=6.3 \mathrm{~Hz}) . \delta_{\mathrm{C}}\left(75 \mathrm{MHz}, \mathrm{CDCl}_{3}\right): 159.3(\mathrm{ArC}), 157.5(\mathrm{CO}), 138.0(\operatorname{ArC}), 135.8$ (ArC), 135.2 (=CHPh), 133.9 (CH=), 130.8 (ArC), 129.6 (2 x ArCH), $128.8(\mathrm{ArCH})$, 128.6 (2 x $\mathrm{ArCH}), 128.5(\mathrm{ArCH}), 128.1$ (2 x $\mathrm{ArCH}), 128.0(2 \times \mathrm{ArCH}), 126.8$ (2 x ArCH), $125.1(\mathrm{CH}=), 118.6\left(=\mathrm{CH}_{2}\right), 114.0(2 \mathrm{x} \mathrm{ArCH}), 74.9(\mathrm{C} 5), 73.2\left(\mathrm{CH}_{2}\right), 71.5(\mathrm{CH})$, $71.1\left(\mathrm{CH}_{2}\right), 69.1\left(\mathrm{CH}_{2}\right), 61.4(\mathrm{C} 4), 56.4(\mathrm{CH}), 55.4\left(\mathrm{OCH}_{3}\right), 38.8\left(\mathrm{CH}_{2}\right), 20.3(\mathrm{Me})$. ESIMS m/z $550(80 \%)[\mathrm{M}+\mathrm{Na}]^{+}, 528(18 \%)[\mathrm{M}+\mathrm{H}]^{+}$, HRESIMS found 528.2737, calcd for $\mathrm{C}_{33} \mathrm{H}_{38} \mathrm{NO}_{5}, 528.2750[\mathrm{M}+\mathrm{H}]^{+}$. (1R,5S,7aS)-5-(Benzyloxymethyl)-1-((S)-2-(4-methoxybenzyloxy)propyl)-1,7adihydropyrrolo[1,2-c]oxazol-3(5H)-one (16). A solution of the oxazolidinone 15 (239 mg, 
$0.45 \mathrm{mmol}$ ) and Grubbs' II ruthenium catalyst (19 $\mathrm{mg}, 0.02 \mathrm{mmol}$ ) in anhydrous $\mathrm{CH}_{2} \mathrm{Cl}_{2}$ $(8 \mathrm{~mL})$ under a nitrogen atmosphere was heated at reflux for $18 \mathrm{~h}$. The reaction mixture was cooled to rt and was then concentrated in vacuo to give a black semi-solid. Purification by flash column chromatography with increasing polarity from 0:100 to 30:70 of EtOAc/petrol as eluent gave the title compound (172 mg, 90\%) as a yellow oil. $R_{f} 0.24$ (30:70 EtOAc/petrol). $[\alpha]_{D}^{25}-22.5\left(c\right.$ 0.12, $\left.\mathrm{CHCl}_{3}\right)$. IR $v_{\max }\left(\mathrm{cm}^{-1}\right): 2967,2864$, $1745,1610,1513,1454,1375,1246,1213,1072,820,746,697,608 . \delta_{\mathrm{H}}(500 \mathrm{MHz}$, $\left.\mathrm{CDCl}_{3}\right): 7.34-7.23(7 \mathrm{H}, \mathrm{m}), 6.86(2 \mathrm{H}, \mathrm{d}, J=8.3 \mathrm{~Hz}), 5.99(1 \mathrm{H}, \mathrm{d}, J=5.9 \mathrm{~Hz}), 5.89(1 \mathrm{H}$, d, $J=5.9 \mathrm{~Hz}), 4.98(1 \mathrm{H}, \mathrm{td}, J=9.3,3.4 \mathrm{~Hz}), 4.80-4.76(2 \mathrm{H}, \mathrm{m}), 4.55(1 \mathrm{H}, \mathrm{d}, J=11.2$ Hz), 4.54 (2H, s), 4.33 (1H, d, $J=11.2 \mathrm{~Hz}), 3.79$ - 3.75 (1H, m), 3.78 (3H, s), 3.52 (2H, d, $J=4.5 \mathrm{~Hz}$ ), 1.72 (1H, ddd, $J=12.4,10.7,3.4 \mathrm{~Hz}), 1.62(1 \mathrm{H}, \mathrm{ddd}, J=10.7,9.3,2.9$ Hz), $1.21(3 \mathrm{H}, \mathrm{d}, J=5.8 \mathrm{~Hz}) . \delta_{\mathrm{C}}\left(125 \mathrm{MHz}, \mathrm{CDCl}_{3}\right): 162.4$ (C3), $159.3(\mathrm{ArC}), 138.0$ (ArC), 132.9 (C7), 130.6 (ArC), 129.5 (2 x $\mathrm{ArCH}), 128.5$ (C6), 128.4 (2 x $\mathrm{ArCH}), 127.7$ (ArCH), 127.6 (2 x ArCH), 113.9 (2 x ArCH), $76.4(\mathrm{C} 1), 73.3\left(\mathrm{OCH}_{2} \mathrm{Ph}\right), 71.4\left(\mathrm{CH}_{2}\right)$, $71.2(\mathrm{CH}), 70.9\left(\mathrm{CH}_{2}\right), 68.2$ (C5), $67.0(\mathrm{C} 7 \mathrm{a}), 55.3\left(\mathrm{OCH}_{3}\right), 40.1\left(\mathrm{CH}_{2}\right), 20.0(\mathrm{Me})$. ESIMS m/z 446 (100\%) $[\mathrm{M}+\mathrm{Na}]^{+}$, HRESIMS found 446.1956, calcd for $\mathrm{C}_{25} \mathrm{H}_{29} \mathrm{NO}_{5} \mathrm{Na}$, $446.1943[\mathrm{M}+\mathrm{Na}]^{+}$.

(1R,5R,6R,7S,7aS)-5-(Benzyloxymethyl)-6,7-dihydroxy-1-((S)-2-(4-

methoxybenzyloxy)propyl)tetrahydropyrrolo[1,2-c]oxazol-3(1H)-one $\quad$ (17). $\quad \mathrm{N}$ methylmorpholine- $\mathrm{N}$-oxide (335 mg, $2.86 \mathrm{mmol}$ ) and potassium osmate dihydrate (26 mg, $0.07 \mathrm{mmol}$ ) were added to a solution of $\mathbf{1 6}$ (605 $\mathrm{mg}, 1.43 \mathrm{mmol}$ ) in 3:1 acetone/water (18 $\mathrm{mL}$ ). The reaction mixture was stirred at $35{ }^{\circ} \mathrm{C}$ for $18 \mathrm{~h}$, concentrated in vacuo, diluted with $\mathrm{H}_{2} \mathrm{O}$ and extracted with EtOAc $(3 \times 30 \mathrm{~mL})$. The combined organic layers were 
dried $\left(\mathrm{MgSO}_{4}\right)$ and concentrated in vacuo to afford a black oil. Purification by flash column chromatography (0:100 to 3:97 $\mathrm{MeOH} / \mathrm{CH}_{2} \mathrm{Cl}_{2}$ as eluent) gave the title compound (629 mg, 96\%) as a yellow oil. $R_{f} 0.18\left(60: 40 \mathrm{EtOAc/petrol).}[\alpha]_{D}^{25}+6.2\left(c\right.\right.$ 0.14, $\left.\mathrm{CHCl}_{3}\right)$. IR $v_{\max }\left(\mathrm{cm}^{-1}\right): 3402,2931,2863,1723,1612,1513,1455,1370,1303,1245,1176,1121$, 1061, 1031, 950, 821, 741, 698. $\delta_{\mathrm{H}}\left(500 \mathrm{MHz}, \mathrm{CDCl}_{3}\right): 7.31-7.20(5 \mathrm{H}, \mathrm{m}), 6.85-6.84$ (2H, m), 4.86 - $4.83(1 \mathrm{H}, \mathrm{m}), 4.60-4.51(3 \mathrm{H}, \mathrm{m}), 4.30(1 \mathrm{H}, \mathrm{d}, J=10.7 \mathrm{~Hz}) 4.24(1 \mathrm{H}, \mathrm{s}$ (br)), 3.91 (1H, s (br)), 3.78 (3H, s), 3.76 - $3.74(1 \mathrm{H}, \mathrm{m}), 3.69$ - 3.67 (1H, m), 3.65 - 3.63 (3H, m), 2.35 (1H, ddd, $J=10.5,8.8,3.4 \mathrm{~Hz}), 1.92(1 \mathrm{H}, \mathrm{td}, J=10.5,4.4 \mathrm{~Hz}$ ), 1.22 (3H, d, $J=4.9 \mathrm{~Hz}) . \delta_{\mathrm{C}}\left(125 \mathrm{MHz}, \mathrm{CDCl}_{3}\right): 163.0(\mathrm{C} 3), 159.3$ (ArC), $138.0(\mathrm{ArC}), 130.6$ (ArC), $129.6(2 \times \mathrm{ArCH}), 128.5(2 \times \mathrm{ArCH}), 127.8(\mathrm{ArCH}), 127.7(2 \times \mathrm{ArCH}), 113.9(2 \times$ ArCH), 76.0 (C7), 74.0 (C1), $73.5\left(\mathrm{CH}_{2}\right), 72.3(\mathrm{C} 6), 72.2(\mathrm{CH}), 70.7\left(\mathrm{CH}_{2}\right), 70.3\left(\mathrm{CH}_{2}\right)$, 65.2 (C7a), 62.5 (C5), $55.4\left(\mathrm{OCH}_{3}\right), 37.5\left(\mathrm{CH}_{2}\right), 20.0$ (Me). ESIMS m/z 480 (100\%) $[\mathrm{M}+\mathrm{Na}]^{+}, 458(10 \%)[\mathrm{M}+\mathrm{H}]^{+}$, HRESIMS found 458.2187, calcd for $\mathrm{C}_{25} \mathrm{H}_{32} \mathrm{NO}_{7}$, $458.2179[\mathrm{M}+\mathrm{H}]^{+}$.

(1R,5R,6R,7S,7aR)-6,7-Bis(benzyloxy)-5-(benzyloxymethyl)-1-((S)-2-(4-

methoxybenzyloxy)propyl)tetrahydropyrrolo[1,2-c]oxazol-3(1H)-one (18): A solution of the diol 17 (18 mg, $0.039 \mathrm{mmol}$ ) and tetrabutylammonium iodide (TBAI) (1 mg, 0.004 mmol) in anhydrous THF $(5 \mathrm{~mL})$ was stirred at $\mathrm{rt}\left(18{ }^{\circ} \mathrm{C}\right)$ for 15 min under a nitrogen atmosphere. Benzyl bromide (20 $\mu \mathrm{L}, 0.157 \mathrm{mmol}$ ) was added and then the solution was cooled to $0{ }^{\circ} \mathrm{C}$. Sodium hydride (50\% dispersion in mineral oil, $6 \mathrm{mg}, 0.117 \mathrm{mmol}$ ) was slowly added and the reaction mixture was allowed to warm to rt and was stirred for $18 \mathrm{~h}$. Quenching with $\mathrm{H}_{2} \mathrm{O}(50 \mathrm{~mL})$ gave a cloudy mixture, which was extracted with $\mathrm{CH}_{2} \mathrm{Cl}_{2}$ (3 x $100 \mathrm{~mL}$ ). The combined organic layers were dried $\left(\mathrm{MgSO}_{4}\right)$ and concentrated in 
vacuo to give a light yellow solid. Purification by flash column chromatography (0:100 to 30:70 EtOAc/petrol as eluent) gave the title compound (25 mg, 100\%) as a colorless oil. $R_{f} 0.70$ (60:40 EtOAc/petrol). $[\alpha]_{D}^{25}+29.1\left(c\right.$ 0.14, $\left.\mathrm{CHCl}_{3}\right) . \mathrm{IR} v_{\max }\left(\mathrm{cm}^{-1}\right): 3031,2929$, 2862, 1750, 1611, 1513, 1455, 1390, 1359, 1303, 1246, 1228, 1065, 1031, 821, 736, 698. $\delta_{\mathrm{H}}\left(500 \mathrm{MHz}, \mathrm{CDCl}_{3}\right): 7.32-7.18(17 \mathrm{H}, \mathrm{m}), 6.84(2 \mathrm{H}, \mathrm{d}, J=7.3 \mathrm{~Hz}), 4.99(1 \mathrm{H}, \mathrm{d}, J=$ $11.2 \mathrm{~Hz}), 4.77(1 \mathrm{H}, \mathrm{dt}, J=7.8,6.6 \mathrm{~Hz}), 4.58-4.48(4 \mathrm{H}, \mathrm{m}), 4.40(1 \mathrm{H}, \mathrm{d}, J=12.2 \mathrm{~Hz})$, $4.37(1 \mathrm{H}, \mathrm{d}, J=12.2 \mathrm{~Hz}), 4.22(1 \mathrm{H}, \mathrm{d}, J=10.7 \mathrm{~Hz}), 4.15(1 \mathrm{H}, \mathrm{dd}, J=7.8,1.5 \mathrm{~Hz}), 3.97$ (1H, dd, $J=7.8,2.4 \mathrm{~Hz}$ ), 3.93 (1H, s (br)), 3.77 - 3.75 (1H, m), 3.73 (3H, s), 3.66 - 3.61 (2H, m), 3.56 (1H, dd, $J=10.2,2.0 \mathrm{~Hz}), 2.09(1 \mathrm{H}, \mathrm{dd}, J=14.2,7.1 \mathrm{~Hz}), 1.79$ - $1.75(1 \mathrm{H}$, m), $1.07(3 \mathrm{H}, \mathrm{d}, J=5.9 \mathrm{~Hz}) . \delta_{\mathrm{C}}\left(125 \mathrm{MHz}, \mathrm{CDCl}_{3}\right): 162.1$ (C3), $159.4(\mathrm{ArC}), 138.3$ (ArC), 138.1 (ArC), 137.7 (ArC), 130.7 (ArC), 129.6 (2 x $\mathrm{ArCH}), 128.6$ (2 x $\mathrm{ArCH})$, 128.5 (2 x $\mathrm{ArCH}), 128.4$ (2 x $\mathrm{ArCH}), 128.1(\mathrm{ArCH}), 127.8$ (5 x $\mathrm{ArCH}), 127.5(\mathrm{ArCH})$, 127.3 (2 x ArCH), 114.0 (2 x ArCH), 83.3 (C6), 77.2 (C7), 73.9 (C1), $73.4\left(\mathrm{CH}_{2}\right), 73.3$ ( $\left(\mathrm{CH}_{2}\right), 73.0\left(\mathrm{CH}_{2}\right), 72.3(\mathrm{CH}), 70.8\left(\mathrm{CH}_{2}\right), 69.3\left(\mathrm{CH}_{2}\right), 64.4(\mathrm{C} 7 \mathrm{a}), 61.1(\mathrm{C} 5), 55.4$ $\left(\mathrm{OCH}_{3}\right), 37.4\left(\mathrm{CH}_{2}\right), 19.9(\mathrm{Me})$. ESIMS m/z $660(70 \%)[\mathrm{M}+\mathrm{Na}]^{+}, 638(3 \%)[\mathrm{M}+\mathrm{H}]^{+}$, HRESIMS found 638.3093, calcd for $\mathrm{C}_{39} \mathrm{H}_{44} \mathrm{NO}_{7}, 638.3118[\mathrm{M}+\mathrm{H}]^{+}$. (1R,5R,6R,7S,7aR)-6,7-Bis(benzyloxy)-5-(benzyloxymethyl)-1-((S)-2hydroxypropyl)tetrahydropyrrolo[1,2-c]oxazol-3(1H)-one (19). Dichloro-5,6dicyanobenzoquinone (103 g, $0.45 \mathrm{mmol}$ ) was added to a solution of $\mathbf{1 8}$ (131 mg, 0.21 mmol) in $\mathrm{CH}_{2} \mathrm{Cl}_{2} / \mathrm{H}_{2} \mathrm{O}(8: 1,9 \mathrm{~mL})$. The reaction mixture was stirred at rt $\left(26{ }^{\circ} \mathrm{C}\right)$ until TLC analysis (50:50 EtOAc/petrol) showed complete consumption of 18 (4 h). Purification by flash column chromatography (increasing polarity from 50:50 to 80:20 of EtOAc/petrol as eluent) gave the title compound (94 mg, 89\%) as a yellow oil. $R_{f} 0.23$ 
(50:50 EtOAc/petrol). $[\alpha]_{D}^{25}+19.7\left(c\right.$ 0.08, $\left.\mathrm{CHCl}_{3}\right) . \mathrm{IR} v_{\max }\left(\mathrm{cm}^{-1}\right): 3452,2972,2864$, $1742,1511,1397,1361,1231,1206,1127,1071,739,699 . \delta_{\mathrm{H}}\left(500 \mathrm{MHz}, \mathrm{CDCl}_{3}\right): 7.33-$ $7.23(15 \mathrm{H}, \mathrm{m}), 5.04(1 \mathrm{H}, \mathrm{d}, J=11.7 \mathrm{~Hz}), 4.79(1 \mathrm{H}, \mathrm{ddd}, J=12.7,8.3,2.9 \mathrm{~Hz}), 4.65(1 \mathrm{H}$, d, $J=11.7 \mathrm{~Hz}), 4.57$ - 4.50 (3H, m), $4.40(1 \mathrm{H}, \mathrm{d}, J=12.2 \mathrm{~Hz}), 4.28(1 \mathrm{H}, \mathrm{d}, J=7.8 \mathrm{~Hz})$, $4.03(1 \mathrm{H}, \mathrm{s}), 3.99-3.98(1 \mathrm{H}, \mathrm{m}), 3.92-3.88(1 \mathrm{H}, \mathrm{m}), 3.76(1 \mathrm{H}, \mathrm{dd}, J=10.2,2.4 \mathrm{~Hz})$, $3.73(1 \mathrm{H}, \mathrm{d}, J=7.8 \mathrm{~Hz}$ ), 3.60 (1H, dd, $J=10.2,2.4 \mathrm{~Hz}$ ), 2.09 (1H, ddd, $J=14.4,8.3,2.4$ Hz), 1.64 (1H, ddd, $J=14.4,9.8,4.4 \mathrm{~Hz}), 1.07(3 \mathrm{H}, \mathrm{d}, J=6.4 \mathrm{~Hz}) . \delta_{\mathrm{C}}\left(125 \mathrm{MHz}, \mathrm{CDCl}_{3}\right)$ : 162.2 (C3), 138.2 (ArC), 138.1 ( $\mathrm{ArC}), 137.7$ (ArC), 128.6 (2 x $\mathrm{ArCH}), 128.5$ (2 x $\mathrm{ArCH})$, $128.4(2 \times \mathrm{ArCH}), 128.1(\mathrm{ArCH}), 127.8$ (5 x $\mathrm{ArCH}), 127.6(\mathrm{ArCH}), 127.4(2 \times \mathrm{ArCH})$, 83.4 (C6), 76.9 (C7), 74.0 (C1), $73.4\left(2 \times \mathrm{CH}_{2}\right), 73.0\left(\mathrm{CH}_{2}\right), 69.4\left(\mathrm{CH}_{2}\right), 65.2(\mathrm{CH}), 64.4$ (C7a), 61.1 (C5), 38.3 ( $\left.\mathrm{CH}_{2}\right), 24.5$ (Me). ESIMS m/z 540 (100\%) [M+Na] $]^{+}, 518$ (48\%) $[\mathrm{M}+\mathrm{H}]^{+}$, HRESIMS found 518.2523, calcd for $\mathrm{C}_{31} \mathrm{H}_{36} \mathrm{NO}_{6}, 518.2543[\mathrm{M}+\mathrm{H}]^{+}$.

\section{General method for hydrolysis of oxazolidinones}

(1R,3S)-1-((2R,3S,4R,5R)-3,4-Bis(benzyloxy)-5-(benzyloxymethyl)pyrrolidin-2-yl)butane1,3-diol (20): Sodium hydroxide (38 mg, $1.66 \mathrm{mmol}$ ) and 3 drops of $\mathrm{H}_{2} \mathrm{O}$ were added to a solution of 19 (171 mg, $0.33 \mathrm{mmol})$ in ethanol ( $3 \mathrm{~mL}$ ). The reaction mixture was stirred and irradiated in a CEM microwave reactor (the temperature control was set at $110{ }^{\circ} \mathrm{C}$ and the maximum applied power at $200 \mathrm{~W}$ ) for $1 \mathrm{~h}$. After the reaction mixture had cooled to rt it was concentrated in vacuo to give a yellow semi-solid. Purification by flash column chromatography (increasing polarity from $0: 100$ to 8:92 of $\mathrm{MeOH} / \mathrm{CH}_{2} \mathrm{Cl}_{2}$ as eluent) gave the title compound (156 mg, 96\%) as a colorless oil. $R_{f} 0.32$ (7.5:92.5 $\left.\mathrm{MeOH} / \mathrm{CH}_{2} \mathrm{Cl}_{2}\right) \cdot[\alpha]_{D}^{25}+31.3\left(c\right.$ 0.06, $\left.\mathrm{CHCl}_{3}\right)$. IR $v_{\max }\left(\mathrm{cm}^{-1}\right): 3355,3029,2894,2858$, $1494,1451,1405,1344,1208,1145,1084,1051,731,694,656 . \delta_{\mathrm{H}}\left(500 \mathrm{MHz}, \mathrm{CDCl}_{3}\right)$ : 
7.35 - $7.24(15 \mathrm{H}), 4.85(1 \mathrm{H}, \mathrm{d}, J=11.2 \mathrm{~Hz}), 4.60(1 \mathrm{H}, \mathrm{d}, J=12.2 \mathrm{~Hz}), 4.55(1 \mathrm{H}, \mathrm{d}, J=$ $12.2 \mathrm{~Hz}), 4.53(1 \mathrm{H}, \mathrm{d}, J=11.2 \mathrm{~Hz}), 4.49(1 \mathrm{H}, \mathrm{d}, J=11.7 \mathrm{~Hz}), 4.43(1 \mathrm{H}, \mathrm{d}, J=11.7 \mathrm{~Hz})$, 4.15 - $4.12(2 \mathrm{H}, \mathrm{m}, J=5.0 \mathrm{~Hz}), 3.99$ - $3.96(1 \mathrm{H}, \mathrm{m}), 3.90(1 \mathrm{H}, \mathrm{dd}, J=5.4,5.0 \mathrm{~Hz}), 3.53$ 3.47 (2H, m), 3.46 - $3.44(1 \mathrm{H}, \mathrm{m}), 3.10(1 \mathrm{H}, \mathrm{dd}, J=8.3,5.4 \mathrm{~Hz}), 1.71$ (1H, ddd, $J=14.4$, 5.4, $2.4 \mathrm{~Hz}), 1.65$ (1H, ddd, $J=14.4,8.8,5.8 \mathrm{~Hz}), 1.18(3 \mathrm{H}, \mathrm{d}, J=6.4 \mathrm{~Hz}) . \delta_{\mathrm{C}}(75 \mathrm{MHz}$, $\mathrm{CDCl}_{3}$ ): 138.0 (ArC), 137.9 (ArC), 137.8 (ArC), 128.6 (2 x $\left.\mathrm{ArCH}\right), 128.5$ (4 x $\left.\mathrm{ArCH}\right)$, 128.2 (3 x ArCH), 128.1 (3 x ArCH), 128.0 (ArCH), 127.9 (2 x ArCH), 80.6 (C4), 79.8 (C3), $73.4\left(\mathrm{CH}_{2}\right), 73.3\left(\mathrm{CH}_{2}\right), 72.6\left(\mathrm{CH}_{2}\right), 70.4(\mathrm{CH}), 69.8\left(\mathrm{CH}_{2}\right), 65.3(\mathrm{CH}), 63.1(\mathrm{C} 2)$, 60.7 (C5), $44.6\left(\mathrm{CH}_{2}\right), 23.9$ (Me). ESIMS m/z $492(100 \%)[\mathrm{M}+\mathrm{H}]^{+}$, HRESIMS found 492.2758, calcd for $\mathrm{C}_{30} \mathrm{H}_{38} \mathrm{NO}_{5}, 492.2750[\mathrm{M}+\mathrm{H}]^{+}$.

\section{General method for mesylation-cyclization}

(1R,3R,5R,6R,7S,7aR)-6,7-Bis(benzyloxy)-5-(benzyloxymethyl)-3-methylhexahydro-1Hpyrrolizin-1-ol (21). Triethylamine ( $40 \mu \mathrm{L}, 0.25 \mathrm{mmol}$ ) was slowly added to a solution of 20 (140 mg, $0.25 \mathrm{mmol})$ in $\mathrm{CH}_{2} \mathrm{Cl}_{2}(12.8 \mathrm{~mL})$ at $0{ }^{\circ} \mathrm{C}$ under a nitrogen atmosphere followed by a $0.13 \mathrm{M}$ solution of methanesulfonyl chloride in anhydrous $\mathrm{CH}_{2} \mathrm{Cl}_{2}(2.2 \mathrm{~mL}$, $\left.0.28 \mathrm{mmol} \mathrm{MeSO}{ }_{2} \mathrm{Cl}\right)$. The reaction mixture was stirred at $0{ }^{\circ} \mathrm{C}$ for $1.5 \mathrm{~h}$ and quenched with sat. aqueous $\mathrm{NaHCO}_{3}$ solution $(3.5 \mathrm{~mL})$ and extracted with $\mathrm{CH}_{2} \mathrm{Cl}_{2}(3 \times 15 \mathrm{~mL})$. The combined organic extracts were dried $\left(\mathrm{MgSO}_{4}\right)$ and concentrated in vacuo to give a yellow oil. Purification by flash column chromatography (increasing polarity from 2:98 to $10: 90$ of $\mathrm{MeOH} / \mathrm{CH}_{2} \mathrm{Cl}_{2}$ as eluent) gave compound 21 (134 mg, 100\%) as a colorless

oil. $R_{f} 0.22\left(5: 95 \mathrm{MeOH} / \mathrm{CH}_{2} \mathrm{Cl}_{2}\right) \cdot[\alpha]_{D}^{25}+16.5\left(c \mathrm{c} 26, \mathrm{CHCl}_{3}\right)$. IR $v_{\max }\left(\mathrm{cm}^{-1}\right): 3354$, 2913, 2865, 1453, 1360, 1207, 1139, 1090, 1026, 732, 696. $\delta_{\mathrm{H}}\left(500 \mathrm{MHz}, \mathrm{CDCl}_{3}\right): 7.33$ $7.27(15 \mathrm{H}, \mathrm{m}), 4.71(1 \mathrm{H}, \mathrm{d}, J=12.2 \mathrm{~Hz}), 4.66(1 \mathrm{H}, \mathrm{dd}, J=8.8,4.4 \mathrm{~Hz}), 4.58$ - 4.50 (5H, 
m), $4.14(1 \mathrm{H}, \mathrm{dd}, J=5.4,4.9 \mathrm{~Hz}), 3.90(1 \mathrm{H}, \mathrm{dd}, J=5.0,4.4 \mathrm{~Hz}), 3.70-3.67(1 \mathrm{H}, \mathrm{m})$, $3.58(1 \mathrm{H}, \mathrm{dd}, J=4.9,4.4 \mathrm{~Hz}), 3.45-3.43(1 \mathrm{H}, \mathrm{m}), 3.39-3.36(2 \mathrm{H}, \mathrm{m}), 1.85$ (2H, dd, $J=$ 7.3, $5.4 \mathrm{~Hz}), 1.17(3 \mathrm{H}, \mathrm{d}, J=6.8 \mathrm{~Hz}) . \delta_{\mathrm{C}}\left(125 \mathrm{MHz}, \mathrm{CDCl}_{3}\right): 138.4(\mathrm{ArC}), 138.3(\mathrm{ArC})$ 138.2 (ArC), 128.5 (2 x $\mathrm{ArCH}), 128.4$ (4 x $\mathrm{ArCH}), 127.9$ (5 x $\mathrm{ArCH}), 127.8$ (3 x $\mathrm{ArCH})$, 127.7 (ArCH), $81.2(\mathrm{C} 2), 76.6(\mathrm{C} 1), 75.8(\mathrm{C} 7 \mathrm{a}), 73.5\left(\mathrm{CH}_{2}\right), 73.1\left(\mathrm{CH}_{2}\right), 72.2\left(\mathrm{CH}_{2}\right), 71.8$ (C8), 71.3 (C7), 60.2 (C3), 56.9 (C5), 42.4 (C6), 16.2 (C9). ESIMS m/z 474 (100\%) $[\mathrm{M}+\mathrm{H}]^{+}$, HRESIMS found 474.2624, calcd for $\mathrm{C}_{30} \mathrm{H}_{36} \mathrm{NO}_{4}, 474.2644[\mathrm{M}+\mathrm{H}]^{+}$.

\section{General method for hydrogenolysis of benzyl ethers}

(1S,2R,3R,5R,7R,7aR)-3-(Hydroxymethyl)-5-methylhexahydro-1H-pyrrolizine-1,2,7-triol

(hyacinthacine $B_{3}$ ) (2). $\mathrm{PdCl}_{2}$ (7 mg, $0.04 \mathrm{mmol}$ ) was added to a $\mathrm{N}_{2}$ flushed solution of 21 (17 mg, $0.036 \mathrm{mmol})$ in $\mathrm{MeOH}(4 \mathrm{~mL})$. The reaction mixture was then stirred at rt under a $\mathrm{H}_{2}$ atmosphere (balloon) for $8 \mathrm{~h}$ and then filtered through a pad of celite and washed with $\mathrm{MeOH}(10 \mathrm{~mL})$. The combined filtrates were concentrated in vacuo to give a colorless film which was dissolved in water $(2 \mathrm{~mL})$ and held for $15 \mathrm{~min}$ in a column containing Amberlyst A-26 ( $\left.\mathrm{OH}^{-}\right)$ion-exchange resin $(1 \mathrm{~g})$. Elution with water $(3 \mathrm{x} 5 \mathrm{~mL})$ followed by evaporation in vacuo gave the title compound (5 mg, 68\%) as a colorless film. $[\alpha]_{D}^{23}+10.8\left(c 0.33, \mathrm{H}_{2} \mathrm{O}\right)$. [Lit. ${ }^{3 \mathrm{~b}}[\alpha]_{D}+3.1\left(c 0.33, \mathrm{H}_{2} \mathrm{O}\right)$, temperature not reported]. IR $v_{\max }\left(\mathrm{cm}^{-1}\right): 3317,2960,2929,2878,1652,1338,1133 . \delta_{\mathrm{H}}\left(500 \mathrm{MHz}, \mathrm{CD}_{3} \mathrm{OD}\right): 4.52$ (1H, m, H7), 4.04 (1H, t, $J=4.4 \mathrm{~Hz}, \mathrm{H} 1), 3.91$ (1H, dd, $J=4.2,7.3 \mathrm{~Hz}, \mathrm{H} 2), 3.57(1 \mathrm{H}$, dd, $\left.J=4.9,11.0 \mathrm{~Hz}, \mathrm{H}_{\mathrm{A}}\right), 3.53$ (1H, dd, $\left.J=4.5,11.1 \mathrm{~Hz}, \mathrm{H} 8_{\mathrm{B}}\right), 3.50$ (1H, m, H5), 3.30 (1H, t, $J=4.6 \mathrm{~Hz}, \mathrm{H} 7 \mathrm{a}), 3.10$ (1H, ddd, $J=4.7,4.97 .3 \mathrm{~Hz}, \mathrm{H} 3), 1.86-1.82$ (2H, m, H6 $\alpha$ and $\mathrm{H6}_{\beta}$ ), 1.19 (3H, d, $\left.J=6.9 \mathrm{~Hz}, \mathrm{H9}\right) . \delta_{\mathrm{H}}\left(75 \mathrm{MHz}, \mathrm{CD}_{3} \mathrm{OD}\right): 76.5$ (C2), 76.2 (C7a), 
71.4 (C1), 70.6 (C7), 64.2 (C8), 63.0 (C3), 56.4 (C5), 43.5 (C6), 16.7 (C9). ESIMS m/z $204(100 \%)[\mathrm{M}+\mathrm{H}]^{+}$. HRMS found 204.1232, calcd for $\mathrm{C}_{9} \mathrm{H}_{18} \mathrm{NO}_{4}, 204.1236[\mathrm{M}+\mathrm{H}]^{+}$.

\section{Synthesis of hyacinthacine $B_{7}(3)$ and 7-epi-hyacinthacine $B_{7}(6)$}

\section{General method for the Mitsunobu reaction}

(R)-1-((1R,5R,6R,7S,7aR)-6,7-Bis(benzyloxy)-5-(benzyloxymethyl)-3-

oxohexahydropyrrolo[1,2-c]oxazol-1-yl)propan-2-yl 4-nitrobenzoate (22). A solution of 19 (455 mg, $0.88 \mathrm{mmol}$ ), triphenylphosphine (1038 mg, $3.96 \mathrm{mmol}$ ) and p-nitrobenzoic acid (662 mg, $3.959 \mathrm{mmol}$ ) in toluene $\left(9 \mathrm{~mL}\right.$ ) was cool to $0{ }^{\circ} \mathrm{C}$ and diisopropyl azodicarboxylate $(0.78 \mathrm{~mL}, 3.96 \mathrm{mmol})$ was added. The reaction mixture was allowed to warm to rt $\left(27^{\circ} \mathrm{C}\right)$ and stirred for $24 \mathrm{~h}$. The volatiles were removed in vacuo, extracted with $\mathrm{CH}_{2} \mathrm{Cl}_{2}(3 \times 30 \mathrm{~mL})$, dried $\left(\mathrm{MgSO}_{4}\right)$ and concentrated in vacuo to give a dark brown oil. Purification by flash column chromatography (increasing polarity from 0:100 to 10:90 of $\mathrm{MeOH} / \mathrm{CH}_{2} \mathrm{Cl}_{2}$ as eluent) gave the title compound (498 mg, 85\%) as a yellow oil. $R_{f} 0.30$ (30:70 EtOAc/petrol). $[\alpha]_{D}^{25}-26.6$ (c 0.64, $\left.\mathrm{CHCl}_{3}\right) . \mathrm{IR} v_{\max }\left(\mathrm{cm}^{-1}\right): 2934,2864$, $1752,1719,1525,1346,1274,1100,737 . \delta_{\mathrm{H}}\left(500 \mathrm{MHz}, \mathrm{CDCl}_{3}\right): 8.24(2 \mathrm{H}, \mathrm{d}, J=8.8 \mathrm{~Hz})$, $8.13(2 \mathrm{H}, \mathrm{d}, J=8.8 \mathrm{~Hz}), 7.35$ - $7.20(15 \mathrm{H}, \mathrm{m}), 5.27$ - $5.21(1 \mathrm{H}, \mathrm{m}), 5.10(1 \mathrm{H}, \mathrm{d}, J=11.7$ Hz), $4.72(1 \mathrm{H}, \mathrm{dt}, J=7.3,6.6 \mathrm{~Hz}), 4.66(1 \mathrm{H}, \mathrm{d}, J=11.7 \mathrm{~Hz}), 4.57(1 \mathrm{H}, \mathrm{d}, J=11.7 \mathrm{~Hz})$, $4.52(1 \mathrm{H}, \mathrm{d}, J=11.7 \mathrm{~Hz}), 4.51(1 \mathrm{H}, \mathrm{d}, J=11.7 \mathrm{~Hz}), 4.38(1 \mathrm{H}, \mathrm{d}, J=11.7 \mathrm{~Hz}), 4.32(1 \mathrm{H}$, dd, $J=7.8,2.0 \mathrm{~Hz}$ ), 4.07 (1H, s, H7), 4.00 (1H, dt, $J=7.8,2.9 \mathrm{~Hz}), 3.76$ (2H, d, $J=8.3$ Hz), $3.59(1 \mathrm{H}, J=10.3,2.4 \mathrm{~Hz}), 2.42(1 \mathrm{H}, \mathrm{dt}, J=14.6,7.8 \mathrm{~Hz}), 2.07(1 \mathrm{H}, \mathrm{dt}, J=14.6$, 4.4 Hz), $1.31(3 \mathrm{H}, \mathrm{d}, J=6.4 \mathrm{~Hz}) . \delta_{\mathrm{C}}\left(125 \mathrm{MHz}, \mathrm{CDCl}_{3}\right): 164.2(\mathrm{CO}), 161.8$ (C3), 150.6 (ArC), 138.1 (ArC), 137.8 (ArC), 137.4 (ArC), 135.7 (ArC), 130.8 (2 x ArCH), 128.6 (2 x $\mathrm{ArCH}), 128.5$ ( 2 x $\mathrm{ArCH}), 128.4(2 \times \mathrm{ArCH}), 128.2(\mathrm{ArCH}), 127.8$ (6 x $\mathrm{ArCH}), 127.7$ 
(2 x ArCH), 127.4 (2 x $\mathrm{ArCH}), 123.6$ (2 x $\mathrm{ArCH}), 83.3$ (C6), 76.7 (C7), $73.4\left(2 \times \mathrm{CH}_{2}\right)$, $73.0\left(\mathrm{CH}_{2}\right), 72.8(\mathrm{C} 1), 70.3(\mathrm{CH}), 69.2\left(\mathrm{CH}_{2}\right), 63.9(\mathrm{C} 7 \mathrm{a}), 61.1(\mathrm{C}), 35.5\left(\mathrm{CH}_{2}\right), 22.1$ (Me). ESIMS m/z 667 (100\%) $[\mathrm{M}+\mathrm{H}]^{+}$. HRASAPMS found 667.2671, calcd for $\mathrm{C}_{38} \mathrm{H}_{39} \mathrm{~N}_{2} \mathrm{O}_{9}, 667.2656[\mathrm{M}+\mathrm{H}]^{+}$

(1R,3R)-1-((2R,3S,4R,5R)-3,4-Bis(benzyloxy)-5-(benzyloxymethyl)pyrrolidin-2-yl)butane1,3-diol (23). Following the general method for hydrolysis of an oxazolidinone, compound 22 (167 mg, $0.25 \mathrm{mmol}$ ) was treated with sodium hydroxide (58 mg, 2.51 mmol) in ethanol (3 mL) and 3 drops of $\mathrm{H}_{2} \mathrm{O}$ at $110{ }^{\circ} \mathrm{C}$ in a CEM microwave reactor. Purification by flash column chromatography (0:100 to $5: 95 \mathrm{MeOH} / \mathrm{CH}_{2} \mathrm{Cl}_{2}$ as eluent) gave the title compound (120 mg, 97\%) as a colorless oil. $R_{f} 0.30\left(5: 95 \mathrm{MeOH} / \mathrm{CH}_{2} \mathrm{Cl}_{2}\right)$. $[\alpha]_{D}^{25}+18.7\left(c\right.$ 0.83, $\left.\mathrm{CHCl}_{3}\right) . \mathrm{IR} v_{\max }\left(\mathrm{cm}^{-1}\right): 3323,3030,2864,1496,1453,1360,1208$ 1075, 915, 835, 736, 640. $\delta_{\mathrm{H}}\left(500 \mathrm{MHz}, \mathrm{CDCl}_{3}\right): 7.33-7.27(15 \mathrm{H}), 4.88(1 \mathrm{H}, \mathrm{d}, J=11.7$ Hz), $4.61(1 \mathrm{H}, \mathrm{d}, J=11.7 \mathrm{~Hz}), 4.56(1 \mathrm{H}, \mathrm{d}, J=11.7 \mathrm{~Hz}), 4.53(1 \mathrm{H}, \mathrm{d}, J=11.7 \mathrm{~Hz}), 4.50$ $(1 \mathrm{H}, \mathrm{d}, J=12.2 \mathrm{~Hz}), 4.44(1 \mathrm{H}, \mathrm{d}, J=12.2 \mathrm{~Hz}), 4.17(1 \mathrm{H}, \mathrm{t}, J=4.4 \mathrm{~Hz}), 4.08-4.05(1 \mathrm{H}$, m), 4.03 - $4.01(1 \mathrm{H}, \mathrm{m}), 3.89$ (1H, dd, $J=5.8,4.4 \mathrm{~Hz}), 3.54(1 \mathrm{H}, \mathrm{dd}, J=11.2,5.4 \mathrm{~Hz})$, 3.48 - $3.46(2 \mathrm{H}, \mathrm{m}), 3.02(1 \mathrm{H}, \mathrm{dd}, J=7.3,4.4 \mathrm{~Hz}), 1.72(1 \mathrm{H}, \mathrm{d}, J=14.2 \mathrm{~Hz}), 1.44(1 \mathrm{H}$, dt, $J=14.2,9.8 \mathrm{~Hz}), 1.16(3 \mathrm{H}, \mathrm{d}, J=5.8 \mathrm{~Hz}) . \delta_{\mathrm{C}}\left(125 \mathrm{MHz}, \mathrm{CDCl}_{3}\right): 138.1(\operatorname{ArC}), 138.0$ (ArC), 137.9 (ArC), 128.7 (2 x ArCH), 128.5 (2 x ArCH), 128.2 (2 x ArCH), 128.1 (3 x ArCH), 128.0 (3 x ArCH), 127.8 (3 x ArCH), $81.3(\mathrm{C} 4), 79.2(\mathrm{CH}), 73.5\left(\mathrm{CH}_{2}\right), 73.3$ ( $\left(\mathrm{CH}_{2}\right), 72.9$ (C)), $72.8\left(\mathrm{CH}_{2}\right), 70.2\left(\mathrm{CH}_{2}\right), 68.3(\mathrm{CH}), 63.1(\mathrm{C} 2), 60.4(\mathrm{C}), 42.6\left(\mathrm{CH}_{2}\right)$, 23.8 (Me). ESIMS m/z 492 (100\%) $[\mathrm{M}+\mathrm{H}]^{+}$, HRESIMS found 492.2765, calcd for $\mathrm{C}_{30} \mathrm{H}_{38} \mathrm{NO}_{5}, 492.2750[\mathrm{M}+\mathrm{H}]^{+}$. 
(1R,3S,5R,6R,7S,7aR)-6,7-Bis(benzyloxy)-5-(benzyloxymethyl)-3-methylhexahydro-1Hpyrrolizin-1-ol (24). Following the general method for mesylation-cyclization, compound 23 (259 mg, $0.53 \mathrm{mmol})$ was treated with triethylamine (73 $\mu \mathrm{L}, 0.53 \mathrm{mmol}), 0.13 \mathrm{M}$ solution of methanesulfonyl chloride in anhydrous $\mathrm{CH}_{2} \mathrm{Cl}_{2}(4.04 \mathrm{~mL}, 0.53 \mathrm{mmol}$ $\left.\mathrm{MeSO}_{2} \mathrm{Cl}\right)$ in $\mathrm{CH}_{2} \mathrm{Cl}_{2}(28 \mathrm{~mL})$ at $0{ }^{\circ} \mathrm{C}$ for $1.5 \mathrm{~h}$. Purification by flash column chromatography (0:100 to $10: 90 \mathrm{MeOH} / \mathrm{CH}_{2} \mathrm{Cl}_{2}$ as eluent) gave the title compound (198 mg, 77\%) as a colorless oil. $R_{f} 0.30\left(5: 95 \mathrm{MeOH} / \mathrm{CH}_{2} \mathrm{Cl}_{2}\right)$. $[\alpha]_{D}^{25}+21.7$ (c 1.03, $\left.\mathrm{CHCl}_{3}\right)$. IR $v_{\max }\left(\mathrm{cm}^{-1}\right): 3360,3030,2922,2862,1469,1452,1359,1310,1208,1094,1048,1027$, 914, 735, 696. $\delta_{\mathrm{H}}\left(500 \mathrm{MHz}, \mathrm{CDCl}_{3}\right): 7.32-7.27(15 \mathrm{H}, \mathrm{m}), 4.74(1 \mathrm{H}, J=11.7 \mathrm{~Hz}), 4.67$ (1H, td, 7.8, 6.6), 4.55 - $4.48(5 \mathrm{H}, \mathrm{m}), 4.06(1 \mathrm{H}, \mathrm{t}, J=4.6 \mathrm{~Hz}), 3.92(1 \mathrm{H}, \mathrm{dd}, J=5.6,4.4$ Hz), 3.45 - $3.41(3 \mathrm{H}, \mathrm{m}), 3.09$ (1H, dd, $J=10.1,5.6 \mathrm{~Hz}), 3.06$ - $3.02(1 \mathrm{H}, \mathrm{m}), 2.27(1 \mathrm{H}$, dt, $J=11.9,6.1 \mathrm{~Hz}), 1.59(1 \mathrm{H}, \mathrm{td}, J=11.9,9.8 \mathrm{~Hz}), 1.14(3 \mathrm{H}, \mathrm{d}, J=6.1 \mathrm{~Hz}) . \delta_{\mathrm{C}}(75 \mathrm{MHz}$, $\mathrm{CDCl}_{3}$ ): 138.7 (ArC), 138.5 (ArC) 138.2 (ArC), 128.5 (4 x $\left.\mathrm{ArCH}\right), 128.4$ (2 x $\left.\mathrm{ArCH}\right)$, 127.9 (4 x $\mathrm{ArCH}), 127.8$ (2 x ArCH), 127.7 (3 x $\mathrm{ArCH}), 82.0$ (C2), 77.6 (C1), $73.4\left(\mathrm{CH}_{2}\right)$, 73.3 (C7a), $73.2\left(\mathrm{CH}_{2}\right), 72.4\left(\mathrm{CH}_{2}\right), 71.7$ (C8), 71.0 (C7), 68.2 (C3), 62.4 (C5), 44.0 (C6), 22.0 (C9). ESIMS m/z 474 (100\%) $[\mathrm{M}+\mathrm{H}]^{+}$, HRESIMS found 474.2665, calcd for $\mathrm{C}_{30} \mathrm{H}_{36} \mathrm{NO}_{4}, 474.2644[\mathrm{M}+\mathrm{H}]^{+}$. (1S,2R,3S,5R,7R,7aR)-3-(Hydroxymethyl)-5-methylhexahydro-1H-pyrrolizine-1,2,7-triol (putative hyacinthacine $B_{7}$ ) (3). Following the general method for hydrogenolysis of benzyl ethers, the alcohol 24 (27 mg, $0.059 \mathrm{mmol})$ was treated with $\mathrm{PdCl}_{2}(16 \mathrm{mg}, 0.09$ mmol) and $\mathrm{MeOH}(2 \mathrm{~mL})$ at $\mathrm{rt}$ for $3 \mathrm{~h}$. The title compound (10 mg, $84 \%)$ was obtained as a colorless film. $[\alpha]_{D}^{24}+31.2\left(c 0.20, \mathrm{CHCl}_{3}\right) \cdot \delta_{\mathrm{H}}\left(500 \mathrm{MHz}, \mathrm{D}_{2} \mathrm{O}\right): 4.60(1 \mathrm{H}, \mathrm{ddd}, J=$ 5.8, 7.0, 9.2 Hz), $4.13(1 \mathrm{H}$, app. t, $J=4.0 \mathrm{~Hz}), 4.03(1 \mathrm{H}, \mathrm{dd}, J=4.0,9.1 \mathrm{~Hz}), 3.74(1 \mathrm{H}$, 
dd, $J=4.9,11.7 \mathrm{~Hz}$ ), 3.70 (1H, dd, $J=4.9,11.7 \mathrm{~Hz}), 3.32(1 \mathrm{H}, \mathrm{dd}, J=4.0,5.8 \mathrm{~Hz}), 3.06$ - 2.97 (1H, m), 2.81 (1H, app. dd, $J=4.9,9.1 \mathrm{~Hz}), 2.38$ (1H, ddd, $J=5.0,7.0,12.2 \mathrm{~Hz}$ ), $1.60(1 \mathrm{H}, \operatorname{ddd}, J=9.3,11.0,12.2 \mathrm{~Hz}), 1.17(1 \mathrm{H}, \mathrm{d}, J=6.3 \mathrm{~Hz}) . \delta_{\mathrm{C}}\left(125 \mathrm{MHz}, \mathrm{D}_{2} \mathrm{O}\right): 80.3$ (C2), 75.8 (C1), 74.0 (C3), 73.5 (C7), 77.6 (C7a), 67.8 (C8), 67.4 (C5), 48.4 (C6), 24.7 (C9). ESIMS m/z 204 (100\%) [M+H] $]^{+}$

\section{General method for Swern oxidation}

(3S,5R,6R,7S,7aS)-6,7-Bis(benzyloxy)-5-(benzyloxymethyl)-3-methylhexahydro-1Hpyrrolizin-1-one (25). Oxalyl chloride (79 $\mu \mathrm{L}, 0.92 \mathrm{mmol}$ ) was dropwise via syringe in to a stirred solution of DMSO $(130 \mu \mathrm{L}, 1.84 \mathrm{mmol})$ in $\mathrm{CH}_{2} \mathrm{Cl}_{2}(5 \mathrm{~mL})$ at $-78{ }^{\circ} \mathrm{C}$. The solution was stirred at $-78{ }^{\circ} \mathrm{C}$ for $5 \mathrm{~min}$ and then a solution of $24(43 \mathrm{mg}, 0.09 \mathrm{mmol})$ in $\mathrm{CH}_{2} \mathrm{Cl}_{2}\left(2 \mathrm{~mL}\right.$ ) cooled to $-78{ }^{\circ} \mathrm{C}$ was added dropwise via syringe, followed by $\mathrm{Et}_{3} \mathrm{~N}$ (513 $\mu \mathrm{L}, 3.68 \mathrm{mmol})$. The reaction mixture was stirred at $-78{ }^{\circ} \mathrm{C}$ for $1 \mathrm{~h}$ and then poured into $\mathrm{H}_{2} \mathrm{O}(40 \mathrm{~mL})$ and extracted with $\mathrm{Et}_{2} \mathrm{O}(3 \times 30 \mathrm{~mL})$. The combined organic extracts were washed with brine, dried $\left(\mathrm{MgSO}_{4}\right)$, and concentrated in vacuo to give a yellow oil. Purification by flash column chromatography (increasing polarity from 0:100 to 10:90 of $\mathrm{MeOH} / \mathrm{CH}_{2} \mathrm{Cl}_{2}$ as eluent) gave the title compound 25 (27 mg, 63\%) as a colorless oil, and recovered 24 (13.2 mg, 30\%). $R_{f} 0.61\left(5: 95 \mathrm{MeOH} / \mathrm{CH}_{2} \mathrm{Cl}_{2}\right) .[\alpha]_{D}^{25}+28.2$ (c 0.32, $\left.\mathrm{CHCl}_{3}\right)$. IR $v_{\max }\left(\mathrm{cm}^{-1}\right)$ : 3030, 2864, 1750, 1698, 1452, 1361, 1270, 1207, 1098, 736, 661. $\delta_{\mathrm{H}}\left(500 \mathrm{MHz}, \mathrm{CDCl}_{3}\right): 7.32-7.23(15 \mathrm{H}, \mathrm{m}), 4.65(1 \mathrm{H}, \mathrm{d}, J=11.7 \mathrm{~Hz}), 4.60(1 \mathrm{H}, \mathrm{d}, J=$ $12.2 \mathrm{~Hz}), 4.59(1 \mathrm{H}, \mathrm{d}, J=11.7 \mathrm{~Hz}), 4.51(1 \mathrm{H}, \mathrm{d}, J=12.2 \mathrm{~Hz}), 4.50(1 \mathrm{H}, \mathrm{d}, J=11.7 \mathrm{~Hz})$, $4.36(1 \mathrm{H}, \mathrm{d}, J=11.7 \mathrm{~Hz}), 4.18(1 \mathrm{H}, \mathrm{t}, J=3.4 \mathrm{~Hz}), 3.91(1 \mathrm{H}, \mathrm{dd}, J=8.8,3.4 \mathrm{~Hz}), 3.69$ (1H, d, $J=3.4 \mathrm{~Hz}$ ), $3.63(1 \mathrm{H}, \mathrm{dd}, J=9.8,3.4 \mathrm{~Hz}), 3.56(1 \mathrm{H}, \mathrm{dd}, J=9.8,4.9 \mathrm{~Hz}), 3.50$ 3.46 (1H, m), 3.35 (1H, dt, $J=8.8,4.4 \mathrm{~Hz}), 2.61(1 \mathrm{H}, \mathrm{dd}, J=17.6,6.8 \mathrm{~Hz}), 2.10(1 \mathrm{H}, \mathrm{dd}$, 
$J=17.6,8.3 \mathrm{~Hz}), 1.21(3 \mathrm{H}, \mathrm{d}, J=5.9 \mathrm{~Hz}) . \delta_{\mathrm{C}}\left(125 \mathrm{MHz}, \mathrm{CDCl}_{3}\right): 214.7(\mathrm{C} 7), 138.5$

(ArC), 138.4 (ArC), 137.9 (ArC), 128.5 (2 x $\mathrm{ArCH}), 128.4$ (4 x $\mathrm{ArCH}), 128.0$ (3 x $\mathrm{ArCH})$, 127.9 (4 x ArCH), 127.8 (2 x ArCH), $83.4(\mathrm{C} 2), 78.8(\mathrm{C} 1), 73.8\left(\mathrm{CH}_{2}\right), 73.5\left(\mathrm{CH}_{2}\right), 73.1$

( $\mathrm{CH}_{2}$ ), 72.0 (C8), 71.8 (C7a), 69.1 (C3), 60.7 (C5), 46.6 (C6), 22.5 (C9). ESIMS m/z 472 (100\%) $[\mathrm{M}+\mathrm{H}]^{+}$. HRASAPMS found 472.2494, calcd for $\mathrm{C}_{30} \mathrm{H}_{34} \mathrm{NO}_{4}, 472.2488[\mathrm{M}+\mathrm{H}]^{+}$.

General method for the reduction of a ketone to a secondary alcohol with Lselectride $^{\circledR}$ (1S,3S,5R,6R,7S,7aR)-6,7-Bis(benzyloxy)-5-(benzyloxymethyl)-3-methylhexahydro-1Hpyrrolizin-1-ol (26). A solution of the cyclic ketone 25 (63 mg, $0.13 \mathrm{mmol}$ ) in THF (5 mL) was cooled to $-78{ }^{\circ} \mathrm{C}$ and then L-selectride ${ }^{\circledR}(1.0 \mathrm{M}$ solution in THF, $536 \mu \mathrm{L}, 0.54 \mathrm{mmol})$ was slowly added dropwise. The reaction mixture was stirred at $-78^{\circ} \mathrm{C}$ for $1 \mathrm{~h}$, warm to rt $\left(22{ }^{\circ} \mathrm{C}\right)$ and stirred for $2 \mathrm{~h}$. Ammonia solution $(1.0 \mathrm{M}, 24 \mathrm{~mL})$ was added and the resulting mixture was extracted with EtOAc (3 x $50 \mathrm{~mL})$. The combined organic extracts was washed with brine, dried $\left(\mathrm{K}_{2} \mathrm{CO}_{3}\right)$ and concentrated in vacuo to give a light brown film. Purification by flash column chromatography (increasing polarity from 0:100 to 10:90 of $\mathrm{MeOH} / \mathrm{CH}_{2} \mathrm{Cl}_{2}$ as eluent) gave the title compound (44 mg, $70 \%$ ) as a colorless oil. $R_{f} 0.34\left(5: 95 \mathrm{MeOH} / \mathrm{CH}_{2} \mathrm{Cl}_{2}\right)$. $[\alpha]_{D}^{25}+36.2\left(c 1.26, \mathrm{CHCl}_{3}\right)$. IR $v_{\max }\left(\mathrm{cm}^{-1}\right): 3415$, 3030, 2864, 1696, 1452, 1363, 1204, 1098, 1024, 736, 697. $\delta_{\mathrm{H}}\left(500 \mathrm{MHz}, \mathrm{CDCl}_{3}\right): 7.33$ $7.28(15 \mathrm{H}, \mathrm{m}), 4.74(1 \mathrm{H}, \mathrm{d}, J=11.6 \mathrm{~Hz}), 4.59$ (2H, s), $4.53(2 \mathrm{H}, \mathrm{s}), 4.48$ (1H, d, $J=11.6$ Hz), 4.37 - 4.33 (2H, m), 4.02 (1H, dd, $J=5.4,4.9 \mathrm{~Hz}), 3.80$ (1H, s (br)), 3.53 (1H, s (br)), 3.47 - 3.41 (2H, m), 3.33 (1H, s (br)), 2.08 (1H, dd, $J=12.7,5.4 \mathrm{~Hz}), 1.60-1.56$ (1H, m), 1.20 (3H, d, $J=4.4 \mathrm{~Hz}) . \delta_{\mathrm{C}}\left(125 \mathrm{MHz}, \mathrm{CDCl}_{3}\right): 138.2(\mathrm{ArC}), 137.6(\mathrm{ArC})$, 137.5 (ArC), 128.8 (2 x $\mathrm{ArCH}), 128.7$ ( 2 x $\mathrm{ArCH}), 128.6$ (2 x $\mathrm{ArCH}), 128.3$ (2 x $\mathrm{ArCH})$, 
128.1 (4 x ArCH), 128.0 (ArCH), 127.8 (2 x $\mathrm{ArCH}), 80.6$ (C2), 78.6 (C1, br), $73.6\left(\mathrm{CH}_{2}\right)$, $73.5\left(\mathrm{CH}_{2}\right), 73.2$ (C7), $72.9\left(\mathrm{CH}_{2}\right), 71.2$ (C8, br), 70.1 (C7a), 69.3 (C3), 62.3 (C5, br), 45.0 (C6), 21.4 (C9, br). ESIMS m/z 474 [M+H] ${ }^{+}$. HRASAPMS found 474.2642, calcd for $\mathrm{C}_{30} \mathrm{H}_{36} \mathrm{NO}_{4}, 474.2644[\mathrm{M}+\mathrm{H}]^{+}$. (1S,2R,3R,5S,7S,7aR)-3-(Hydroxymethyl)-5-methylhexahydro-1H-pyrrolizine-1,2,7-triol (7-epi-hyacinthacine $B_{7}$ ) (6). Following the general method for hydrogenolysis of benzyl ethers, the alcohol 26 (38 mg, $0.08 \mathrm{mmol})$ was treated with $\mathrm{PdCl}_{2}(22 \mathrm{mg}, 0.12 \mathrm{mmol})$ and $\mathrm{MeOH}(6 \mathrm{~mL})$ at $\mathrm{rt}$ for $3 \mathrm{~h}$. The title compound (14 $\mathrm{mg}, 84 \%)$ was obtained as a colorless film. $[\alpha]_{D}^{25}+18.5\left(c 0.14, \mathrm{H}_{2} \mathrm{O}\right)$. IR $v_{\max }\left(\mathrm{cm}^{-1}\right): 3287,2929,1589,1381,1344$, 1199, 1127, 1081. $\delta_{\mathrm{H}}\left(500 \mathrm{MHz}, \mathrm{D}_{2} \mathrm{O}\right): 4.59(1 \mathrm{H}, \mathrm{t}, J=4.9 \mathrm{~Hz}, \mathrm{H} 7), 4.41(1 \mathrm{H}, \mathrm{dd}, J=5.4$, $4.9 \mathrm{~Hz}, \mathrm{H1}$ ), 3.99 (1H, dd, $J=7.3,4.9 \mathrm{~Hz}, \mathrm{H} 2), 3.71\left(1 \mathrm{H}, \mathrm{dd}, J=11.7,5.4 \mathrm{~Hz}, \mathrm{H} 8_{\mathrm{A}}\right), 3.67$ (1H, dd, $\left.J=11.7,5.8 \mathrm{~Hz}, \mathrm{H}_{\mathrm{B}}\right), 3.58(1 \mathrm{H}, \mathrm{t}, J=5.4 \mathrm{~Hz}, \mathrm{H7a}), 3.40-3.32(1 \mathrm{H}, \mathrm{m}, \mathrm{H})$, $3.04(1 \mathrm{H}$, app. dt, $J=6.3,5.4 \mathrm{~Hz}, \mathrm{H} 3), 2.11\left(1 \mathrm{H}, \mathrm{dd}, J=13.7,5.8 \mathrm{~Hz}, \mathrm{H6}{ }_{\beta}\right), 1.71(1 \mathrm{H}$, ddd, $J=13.7,10.2,4.9 \mathrm{~Hz}, \mathrm{H6}_{\alpha}$ ), 1.18 (3H, d, $\left.J=5.9 \mathrm{~Hz}, \mathrm{H} 9\right) . \delta_{\mathrm{H}}\left(125 \mathrm{MHz}, \mathrm{D}_{2} \mathrm{O}\right): 77.8$ (C2), 75.7 (C7), 75.3 (C1), 73.3 (C3), 70.6 (C7a), 65.5 (C8), 64.2 (C5), 46.5 (C6), 22.8 (C9). ESIMS m/z $204[\mathrm{M}+\mathrm{H}]^{+}$. HRASAPMS found 204.1239, calcd for $\left[\mathrm{C}_{9} \mathrm{H}_{18} \mathrm{NO}_{4}\right]^{+}$, $204.1236[\mathrm{M}+\mathrm{H}]^{+}$.

Synthesis of hyacinthacine $B_{4}(4)$, hyacinthacine $B_{5}(5)$, and 7a-epi-hyacinthacine $B_{3}$ (33)

\section{Swern oxidation of 18}

(R)-3-((2R,3R,4R)-3,4-Bis(benzyloxy)-2-(benzyloxymethyl)-5-oxopyrrolidin-1-yl)butanoic acid (27). The title compound was prepared following the general method for the Swern oxidation using 21 (107 mg, $0.23 \mathrm{mmol}$ ), oxalyl chloride (195 $\mu \mathrm{L}, 2.27 \mathrm{mmol}$ ), DMSO 
(322 $\mu \mathrm{L}, 4.54 \mathrm{mmol})$ and $\mathrm{Et}_{3} \mathrm{~N}(1.26 \mathrm{~mL}, 9.08 \mathrm{mmol})$ in $\mathrm{CH}_{2} \mathrm{Cl}_{2}(17 \mathrm{~mL})$. Purification by flash column chromatography (0:100 to $15: 85 \mathrm{MeOH} / \mathrm{CH}_{2} \mathrm{Cl}_{2}$ as eluent) gave the title compound 27 (17 mg, 16\%), a mixture of 3 unknown ketones (16 mg, 15\%) and recovered 21 (41.4 mg, 39\%), all as colorless oils. $R_{f} 0.50\left(10: 90 \mathrm{MeOH} / \mathrm{CH}_{2} \mathrm{Cl}_{2}\right)$. $[\alpha]_{D}^{25}+33.3\left(c 0.33, \mathrm{CHCl}_{3}\right)$. IR $v_{\max }\left(\mathrm{cm}^{-1}\right): 3062,3030,2931,2867,1696,1495,1452$ 1354, 1307, 1102, 1026, 774, 657. $\delta_{\mathrm{H}}\left(500 \mathrm{MHz}, \mathrm{CDCl}_{3}\right): 7.36$ - $7.26(13 \mathrm{H}, \mathrm{m}), 7.16(2 \mathrm{H}$, d, $J=7.5 \mathrm{~Hz}), 4.87(1 \mathrm{H}, \mathrm{d}, J=12.2 \mathrm{~Hz}), 4.71(1 \mathrm{H}, \mathrm{d}, J=12.2 \mathrm{~Hz}), 4.63(1 \mathrm{H}, \mathrm{d}, J=12.2$ Hz), $4.54(1 \mathrm{H}, \mathrm{d}, J=12.2 \mathrm{~Hz}), 4.43(1 \mathrm{H}, \mathrm{d}, J=11.7 \mathrm{~Hz}), 4.39(1 \mathrm{H}, \mathrm{d}, J=11.7 \mathrm{~Hz}), 4.22$ (1H, d, $J=5.4 \mathrm{~Hz}), 4.05-3.98$ (1H, m), 3.94 (1H, d, $J=5.4 \mathrm{~Hz}), 3.63$ (1H, s (br)), 3.48 (1H, dd, $J=10.2,4.4 \mathrm{~Hz}$ ), 3.47 (1H, dd, $J=10.2,3.4 \mathrm{~Hz}), 2.96(1 \mathrm{H}, \mathrm{dd}, J=16.1,7.3 \mathrm{~Hz}$ ), $2.76(1 \mathrm{H}, \mathrm{dd}, J=16.1,6.8 \mathrm{~Hz}), 1.31(3 \mathrm{H}, \mathrm{d}, J=2.9 \mathrm{~Hz}) . \delta_{\mathrm{C}}\left(75 \mathrm{MHz}, \mathrm{CDCl}_{3}\right): 174.9$ (CO), 172.6 (CO), 137.8 (2 x ArC), 137.5 (ArC), 128.6 (2 x ArCH), 128.5 (4 x $\mathrm{ArCH})$, 128.3 (2 x ArCH), 128.1 (2 x ArCH), $128.0(2 \times \mathrm{ArCH}), 127.9(\mathrm{ArCH}), 127.7$ (2 x ArCH), $75.9(\mathrm{CH}), 75.7(\mathrm{CH}), 73.4\left(\mathrm{CH}_{2}\right), 72.7\left(\mathrm{CH}_{2}\right), 71.9\left(\mathrm{CH}_{2}\right), 68.5\left(\mathrm{CH}_{2}\right), 62.1(\mathrm{CH})$, $47.4(\mathrm{CH}), 38.3\left(\mathrm{CH}_{2}\right), 18.2(\mathrm{Me})$. ESIMS m/z 526 (100\%) [M+Na] ${ }^{+}$. HRASAPMS found 504.2407, calcd for $\mathrm{C}_{30} \mathrm{H}_{34} \mathrm{NO}_{6}, 504.2386[\mathrm{M}+\mathrm{H}]^{+}$.

Swern oxidation of 21 followed by reduction of ketone to secondary alcohols with Lselectride $^{\circledR}$

(1S,3R,5R,6R,7S,7aR)-6,7-Bis(benzyloxy)-5-(benzyloxymethyl)-3-methylhexahydro-1Hpyrrolizin-1-ol (28), (3R,5R,6R,7R,7aS)-6,7-Bis(benzyloxy)-5-(benzyloxymethyl)-3methylhexahydro-1H-pyrrolizin-1-one (29), (1R,3R,5R,6R,7S,7aS)-6,7-Bis(benzyloxy)-5- 
(benzyloxymethyl)-3-methylhexahydro-1H-pyrrolizin-1-ol (30), and (3R,4R,5R)-3,4Bis(benzyloxy)-5-(benzyloxymethyl)-1-((R)-4-hydroxybutan-2-yl)pyrrolidin-2-one (31).

Step 1: Following the general method for the Swern oxidation using DMSO (778 $\mu \mathrm{L}$, $10.96 \mathrm{mmol}$ ), oxalyl chloride (470 $\mu \mathrm{L}, 5.48 \mathrm{mmol}$ ), alcohol 18 (259 mg, $0.55 \mathrm{mmol}$ ), anhydrous $\mathrm{CH}_{2} \mathrm{Cl}_{2}(30 \mathrm{~mL})$ and $\mathrm{Et}_{3} \mathrm{~N}(3.04 \mathrm{~mL}, 21.92 \mathrm{mmol})$ at $-78{ }^{\circ} \mathrm{C}$ a yellow oil was obtained which was used without further purification in the next reaction with LSelectride ${ }^{\circledR}$.

Step 2: Following the general method for reduction of a ketone to a secondary alcohol with L-selectride ${ }^{\circledR}$ the above Swern oxidation crude product in THF $(20 \mathrm{~mL})$ was treated with L-selectride ${ }^{\circledR}(1.0 \mathrm{M}$ solution in THF, $2.19 \mathrm{~mL}, 2.19 \mathrm{mmol})$. Purification by flash column chromatography (2:98 to $15: 85 \mathrm{MeOH} / \mathrm{CH}_{2} \mathrm{Cl}_{2}$ as eluent) gave compounds $\mathbf{2 8}$ (11.7 mg, 4\%), 29 (18.0 mg, 7\%), 30 (20.5 mg, 7\%) and 31 (17.8 mg, 8\%) and recovered 21 (18.1 mg, 7\%).

28: $R_{f} 0.44\left(10: 90 \mathrm{MeOH} / \mathrm{CH}_{2} \mathrm{Cl}_{2}\right) \cdot[\alpha]_{D}^{25}+11.5\left(c 0.33, \mathrm{CHCl}_{3}\right)$. IR $v_{\max }\left(\mathrm{cm}^{-1}\right): 3350$, 3030, 2919, 2868, 1690, 1452, 1363, 1097, 1026, 735, 644. $\delta_{\mathrm{H}}\left(500 \mathrm{MHz}, \mathrm{CDCl}_{3}\right): 7.34-$ $7.26(15 \mathrm{H}, \mathrm{m}), 4.81(1 \mathrm{H}, \mathrm{d}, J=11.7 \mathrm{~Hz}), 4.61(1 \mathrm{H}, \mathrm{d}, J=11.7 \mathrm{~Hz}), 4.59(1 \mathrm{H}, \mathrm{d}, J=11.7$ Hz), $4.55(1 \mathrm{H}, \mathrm{d}, J=11.7 \mathrm{~Hz}), 4.54(2 \mathrm{H}, \mathrm{s}), 4.44-4.39(1 \mathrm{H}, \mathrm{m}), 4.34$ (1H, dd, $J$ = 5.4, $4.9 \mathrm{~Hz}), 4.04$ (1H, dd, $J$ = 5.8, $4.4 \mathrm{~Hz}$ ), 3.83 (1H, s (br)), 3.68 - 3.66 (1H, m), 3.60 - 3.55 (2H, m), 3.46 - $3.43(1 \mathrm{H}, \mathrm{m}), 2.17(1 \mathrm{H}, \mathrm{dt}, J=12.2,6.3 \mathrm{~Hz}), 1.69-1.78(1 \mathrm{H}, \mathrm{m}), 1.28$ (3H, d, $J=6.8 \mathrm{~Hz}) . \delta_{\mathrm{C}}\left(75 \mathrm{MHz}, \mathrm{CDCl}_{3}\right): 138.1(\mathrm{ArC}), 137.5(\mathrm{ArC}), 137.3(\mathrm{ArC}), 128.8$ (4 x $\mathrm{ArCH}), 128.6$ (2 x $\mathrm{ArCH}), 128.4$ (2 x $\mathrm{ArCH}), 128.3$ (2 x $\mathrm{ArCH}), 128.2$ (2 x $\mathrm{ArCH})$, 128.1 (2 x ArCH), $128.0(\mathrm{ArCH}), 81.4(\mathrm{C} 2), 78.3$ (C1), $73.6\left(2 \times \mathrm{CH}_{2}\right), 73.0\left(\mathrm{CH}_{2}\right), 71.4$ (C7, absent), 70.8 (C8, observed in HSQC), 68.3 (C7a), 61.2 (C3), 56.6 (C5, observed in 
HSQC), 43.0 (C6), 16.8 (C9). ESIMS m/z 474 (100\%) [M+H] $]^{+}$. HRASAPMS found 474.2649, calcd for $\mathrm{C}_{30} \mathrm{H}_{36} \mathrm{NO}_{4}, 474.2644[\mathrm{M}+\mathrm{H}]^{+}$.

29: $R_{f} 0.32\left(5: 95 \mathrm{MeOH} / \mathrm{CH}_{2} \mathrm{Cl}_{2}\right) \cdot[\alpha]_{D}^{25}-62.5\left(c \mathrm{c} 0.81, \mathrm{CHCl}_{3}\right)$. IR $v_{\max }\left(\mathrm{cm}^{-1}\right): 3031$, 2926, 2870, 1717, 1452, 1361, 1267, 1097, 737, 697. $\delta_{\mathrm{H}}\left(500 \mathrm{MHz}, \mathrm{CDCl}_{3}\right): 7.32-7.24$ (13H, m), 7.20 (2H, d, $J=7.0 \mathrm{~Hz}), 4.55(2 \mathrm{H}, \mathrm{d}, J=12.0 \mathrm{~Hz}), 4.45(1 \mathrm{H}, J=12.0 \mathrm{~Hz})$, $4.43(2 \mathrm{H}, \mathrm{d}, J=12.0 \mathrm{~Hz}), 4.34(1 \mathrm{H}, J=12.0 \mathrm{~Hz}), 4.15(1 \mathrm{H}, \mathrm{s}), 3.99(1 \mathrm{H}, \mathrm{s}), 3.71-3.67$ (2H, m), $3.54-3.48(3 \mathrm{H}, \mathrm{m}), 2.25-2.13(2 \mathrm{H}, \mathrm{m}), 1.36(3 \mathrm{H}, \mathrm{d}, J=6.7 \mathrm{~Hz}) . \delta_{\mathrm{C}}(125 \mathrm{MHz}$, $\left.\mathrm{CDCl}_{3}\right)$ : 218.0 (C7), 138.4 ( $\left.\mathrm{ArC}\right), 137.6$ ( 2 x ArC), 128.7 (2 x $\left.\mathrm{ArCH}\right), 128.6$ (2 x $\left.\mathrm{ArCH}\right)$, 128.5 (2 x $\mathrm{ArCH}), 128.0$ (2 x $\mathrm{ArCH}), 127.8$ (4 x $\mathrm{ArCH}), 127.6$ (3 x $\mathrm{ArCH}), 84.0$ (C1), 83.0 (C2), 76.4 (C7a), $73.3\left(\mathrm{CH}_{2}\right), 73.0(\mathrm{C} 8), 71.6\left(\mathrm{CH}_{2}\right), 70.9\left(\mathrm{CH}_{2}\right), 62.7$ (C3), 54.5 (C5), 43.1 (C6), 17.2 (C9). ESIMS m/z $472(100 \%)[M+H]^{+}$. HRASAPMS found 472.2469, calcd for $\mathrm{C}_{30} \mathrm{H}_{34} \mathrm{NO}_{4}, 472.2488[\mathrm{M}+\mathrm{H}]^{+}$.

30: $R_{f} 0.69\left(20: 80 \mathrm{MeOH} / \mathrm{CH}_{2} \mathrm{Cl}_{2}\right) \cdot[\alpha]_{D}^{25}+30.3\left(c 0.12, \mathrm{CHCl}_{3}\right)$. IR $v_{\max }\left(\mathrm{cm}^{-1}\right): 3271$, 3030, 2919, 2861, 1454, 1364, 1206, 1102, 1035, 665, 645. $\delta_{\mathrm{H}}\left(500 \mathrm{MHz}, \mathrm{CDCl}_{3}\right): 7.35$ $7.18(15 \mathrm{H}, \mathrm{m}), 4.71(1 \mathrm{H}, \mathrm{d}, J=12.7 \mathrm{~Hz}), 4.68(1 \mathrm{H}, \mathrm{d}, J=12.7 \mathrm{~Hz}), 4.56(2 \mathrm{H}, \mathrm{s}), 4.45$ (1H, d, $J=11.7 \mathrm{~Hz}), 4.39(1 \mathrm{H}, \mathrm{d}, J=11.7 \mathrm{~Hz}), 4.20(1 \mathrm{H}, \mathrm{dd}, J=7.3,4.9 \mathrm{~Hz}), 4.07-4.04$ (2H, m), 3.85 (1H, s (br)), 3.71 (1H, dd, $J=10.5,2.9 \mathrm{~Hz}$ ), 3.48 (1H, s (br)), 3.33 (1H, dd, $J=10.5,2.0 \mathrm{~Hz}), 3.24-3.20(1 \mathrm{H}, \mathrm{m}), 2.05(1 \mathrm{H}, \mathrm{dd}, J=12.7,5.4 \mathrm{~Hz}), 1.72(1 \mathrm{H}, \mathrm{td}, J=$ 12.7, $3.4 \mathrm{~Hz}), 1.30(3 \mathrm{H}, \mathrm{d}, J=5.8 \mathrm{~Hz}) . \delta_{\mathrm{C}}\left(125 \mathrm{MHz}, \mathrm{CDCl}_{3}\right): 138.8(\mathrm{ArC}), 136.9(2 \mathrm{x}$ ArC), 128.7 ( 2 x ArCH), 128.5 (2 x $\mathrm{ArCH}), 128.3$ (2 x $\mathrm{ArCH}), 128.1$ (2 x $\mathrm{ArCH}), 127.9$ (2 x ArCH), 127.7 (2 x ArCH), 84.1 (C7, observed in $\mathrm{HMBC}), 75.6$ (C1, br), $73.7\left(\mathrm{CH}_{2}\right)$, 73.3 (C2, br), $72.2\left(\mathrm{CH}_{2}\right), 71.8\left(\mathrm{CH}_{2}\right), 71.6$ (C7a, br), 68.0 (C8, observed in HMBC), 62.0 
(C3), 50.2 (C5, observed in HMBC), 46.6 (C6, br), 29.8 (C9). ESIMS m/z 474 (100\%) $[\mathrm{M}+\mathrm{H}]^{+}$. HRASAPMS found 474.2635, calcd for $\mathrm{C}_{30} \mathrm{H}_{36} \mathrm{NO}_{4}, 474.2644[\mathrm{M}+\mathrm{H}]^{+}$.

31: $R_{f} 0.54\left(5: 95 \mathrm{MeOH} / \mathrm{CH}_{2} \mathrm{Cl}_{2}\right) \cdot[\alpha]_{D}^{25}+77.2\left(c \mathrm{0.95}, \mathrm{CHCl}_{3}\right)$. IR $v_{\max }\left(\mathrm{cm}^{-1}\right): 3400$, 2929, 2866, 1645, 1452, 1359, 1259, 1101, 1025, 697. $\delta_{\mathrm{H}}\left(500 \mathrm{MHz}, \mathrm{CDCl}_{3}\right): 7.38-7.16$ (15H, m), $4.93(1 \mathrm{H}, \mathrm{d}, J=12.2 \mathrm{~Hz}), 4.76(1 \mathrm{H}, \mathrm{d}, J=12.2 \mathrm{~Hz}), 4.70(1 \mathrm{H}, \mathrm{d}, J=12.2 \mathrm{~Hz})$, $4.53(1 \mathrm{H}, \mathrm{d}, J=12.2 \mathrm{~Hz}), 4.42(2 \mathrm{H}, \mathrm{s}), 4.36(1 \mathrm{H}, \mathrm{d}, J=4.9 \mathrm{~Hz}), 4.33$ - $4.26(1 \mathrm{H}, \mathrm{m}), 4.01$ (1H, d, $J=4.9 \mathrm{~Hz}), 3.57$ (2H, s (br)), $3.52(1 \mathrm{H}, \mathrm{s}(\mathrm{br})), 3.48(1 \mathrm{H}, \mathrm{dd}, J=10.2,2.9 \mathrm{~Hz})$, $3.44(1 \mathrm{H}, \mathrm{dd}, J=10.2,4.9 \mathrm{~Hz}), 1.74-1.70(2 \mathrm{H}, \mathrm{m}), 1.17(1 \mathrm{H}, \mathrm{d}, J=7.3 \mathrm{~Hz}) . \delta_{\mathrm{C}}(125$ MHz, CDCl $)$ ): 173.8 (CO), 137.9 (2 x ArC), 137.3 (ArC), 128.7 (2 x ArCH), 128.5 (2 x ArCH), 128.4 (2 x $\mathrm{ArCH}), 128.2$ (2 x $\mathrm{ArCH}), 128.1$ ( $\mathrm{ArCH}), 128.0$ (2 x $\mathrm{ArCH}), 127.9$ (ArCH), $127.8(3 \times \mathrm{ArCH}), 76.9(\mathrm{CH}), 76.2(\mathrm{CH}), 73.6\left(\mathrm{CH}_{2}\right), 72.7\left(\mathrm{CH}_{2}\right), 72.3\left(\mathrm{CH}_{2}\right)$, $69.1\left(\mathrm{CH}_{2}\right), 59.9(\mathrm{CH}), 58.6\left(\mathrm{CH}_{2}\right), 45.1(\mathrm{CH}), 36.1\left(\mathrm{CH}_{2}\right), 19.8(\mathrm{Me})$. ESIMS m/z 512 (100\%) $[\mathrm{M}+\mathrm{Na}]^{+}$. HRESIMS found 512.2413, calcd for $\mathrm{C}_{30} \mathrm{H}_{35} \mathrm{NO}_{5} \mathrm{Na}$, 512.2413 $[\mathrm{M}+\mathrm{Na}]^{+}$. (1S,3R,5R,6R,7R,7aR)-6,7-Bis(benzyloxy)-5-(benzyloxymethyl)-3-methylhexahydro-1Hpyrrolizin-1-ol (32): Following the general method for the reduction of a ketone to a secondary alcohol with L-selectride ${ }^{\circledR}$, the ketone 29 (16 mg, $\left.0.034 \mathrm{mmol}\right)$ in THF (6 mL) was treated with L-selectride ${ }^{\circledR}(1.0 \mathrm{M}$ solution in THF, $136 \mu \mathrm{L}, 0.14 \mathrm{mmol})$. Purification by flash column chromatography (2:98 to $10: 90 \mathrm{MeOH} / \mathrm{CH}_{2} \mathrm{Cl}_{2}$ as eluent) gave the title compound (9 mg, 58\%) as a colorless oil. $R_{f} 0.54\left(10: 90 \mathrm{MeOH} / \mathrm{CH}_{2} \mathrm{Cl}_{2}\right) \cdot[\alpha]_{D}^{25}-16.5(c$ 0.47, $\left.\mathrm{CHCl}_{3}\right) . \mathrm{IR} v_{\max }\left(\mathrm{cm}^{-1}\right): 3369,3063,3032,2927,2865,1690,1454,1365,1207$, 1099, 1028, 740, 670. $\delta_{\mathrm{H}}\left(500 \mathrm{MHz}, \mathrm{CDCl}_{3}\right): 7.31-7.24(15 \mathrm{H}, \mathrm{m}), 4.61(1 \mathrm{H}, \mathrm{d}, J=11.6$ 
Hz), $4.56(1 \mathrm{H}, \mathrm{d}, J=11.7 \mathrm{~Hz}), 4.55(1 \mathrm{H}, \mathrm{d}, J=11.7 \mathrm{~Hz}), 4.50(1 \mathrm{H}, \mathrm{d}, J=12.0 \mathrm{~Hz}), 4.46$ (1H, d, $J=11.6 \mathrm{~Hz}), 4.44(1 \mathrm{H}, \mathrm{d}, J=12.0 \mathrm{~Hz}), 4.28(1 \mathrm{H}, \mathrm{s}(\mathrm{br})), 4.18(1 \mathrm{H}, \mathrm{s}), 4.09(1 \mathrm{H}$, s), 3.70 (1H, br), 3.50 (1H, s (br)), 3.45 (1H, dd, $J=9.1,8.8 \mathrm{~Hz}), 3.38$ (1H, s (br)), 3.20 (1H, s (br)), 2.24 (1H, dt, $J=12.5,5.9 \mathrm{~Hz}), 1.37$ (1H, dd, $J=12.5,10.5 \mathrm{~Hz}), 1.24$ (3H, d, $J=6.6 \mathrm{~Hz}) . \delta_{\mathrm{C}}\left(125 \mathrm{MHz}, \mathrm{CDCl}_{3}\right): 138.4(\mathrm{ArC}), 138.2(\mathrm{ArC}), 137.2(\mathrm{ArC}), 128.8(2 \mathrm{x}$ $\mathrm{ArCH}), 128.6$ (4 x $\mathrm{ArCH}), 128.3$ (3 x $\mathrm{ArCH}), 128.0$ ( 2 x $\mathrm{ArCH}), 127.9$ (3 x $\mathrm{ArCH}), 127.8$ (ArCH), 85.6 (C2), 82.6 (C1, br), 73.7 (C7), 73.5 (C7a, observed in the HSQC), 73.4 ( $\left.\mathrm{CH}_{2}\right), 72.8$ (C8, observed in the HSBC), $71.8\left(2 \times \mathrm{CH}_{2}\right), 62.5$ (C3, br), $54.6(\mathrm{C} 5, \mathrm{br})$, 42.9 (C6, br), 17.0 (C9, br). ESIMS m/z 474 (100\%) [M+H] $]^{+}$. HRASAPMS found 474.2652, calcd for $\mathrm{C}_{30} \mathrm{H}_{36} \mathrm{NO}_{4}, 474.2644[\mathrm{M}+\mathrm{H}]^{+}$.

(1S,2R,3R,5R,7S,7aR)-3-(Hydroxymethyl)-5-methylhexahydro-1H-pyrrolizine-1,2,7-triol (hyacinthacine $B_{5}$ ) (5). Following the general method for hydrogenolysis of benzyl ethers, the alcohol 28 (11.7 mg, $0.03 \mathrm{mmol})$ was treated with $\mathrm{PdCl}_{2}(6.6 \mathrm{mg}, 0.04 \mathrm{mmol})$ and MeOH $(2 \mathrm{~mL})$ at $\mathrm{rt}\left(19^{\circ} \mathrm{C}\right)$ for $3 \mathrm{~h}$. The title compound $(1.5 \mathrm{mg}, 21 \%)$ was obtained as a colorless film. $[\alpha]_{D}^{25}-21.6\left(c 0.08, \mathrm{H}_{2} \mathrm{O}\right) .\left[\right.$ Lit. $^{3 \mathrm{c}}[\alpha]_{D}-25.4\left(c 0.26, \mathrm{H}_{2} \mathrm{O}\right)$, temperature not reported]. IR $v_{\max }\left(\mathrm{cm}^{-1}\right): 3299,2953,1587,1555,1399,1044,839,760,692 . \delta_{\mathrm{H}}(500$ MHz, $\left.\mathrm{D}_{2} \mathrm{O}\right): 4.55$ (1H, td, $\left.J=7.1,6.8 \mathrm{~Hz}, \mathrm{H7}\right), 4.34(1 \mathrm{H}, \mathrm{dd}, J=4.4,3.9 \mathrm{~Hz}, \mathrm{H} 1), 4.04$ (1H, dd, $J=7.3,4.4 \mathrm{~Hz}, \mathrm{H} 2), 3.69$ (1H, dd, $J=11.2,4.4 \mathrm{~Hz}, \mathrm{H} 8_{\mathrm{A}}$ ), 3.65 (1H, dd, $J=11.2$, $5.4 \mathrm{~Hz}, \mathrm{H}_{\mathrm{B}}$ ), 3.52 (1H, dd, $\left.J=6.9,4.4 \mathrm{~Hz}, \mathrm{H7a}\right), 3.39$ (1H, td, $\left.J=6.1,5.3 \mathrm{~Hz}, \mathrm{H} 3\right), 3.34$ - $3.30(1 \mathrm{H}, \mathrm{m}, \mathrm{H} 5), 2.19\left(1 \mathrm{H}, \mathrm{dt}, J=12.7,6.3 \mathrm{~Hz}, \mathrm{H6} 6_{\beta}\right), 1.79(1 \mathrm{H}, \mathrm{dt}, J=12.7,8.3 \mathrm{~Hz}$, H6 $\left.{ }_{\alpha}\right), 1.29$ (3H, d, $\left.J=6.8 \mathrm{~Hz}, \mathrm{H} 9\right) . \delta_{\mathrm{C}}\left(75 \mathrm{MHz}, \mathrm{D}_{2} \mathrm{O}\right): 77.6$ (C2), 75.6 (C7), 75.1 (C1), 69.7 (C7a), 66.0 (C8), 65.3 (C3), 57.7 (C5), 44.3 (C6), 18.1 (C9). ESIMS m/z 204 (100\%) $[\mathrm{M}+\mathrm{H}]^{+}$. HRASAPMS found 204.1249, calcd for $\mathrm{C}_{9} \mathrm{H}_{18} \mathrm{NO}_{4}, 204.1236[\mathrm{M}+\mathrm{H}]^{+}$. 
(1R,2R,3R,5R,7S,7aR)-3-(Hydroxymethyl)-5-methylhexahydro-1H-pyrrolizine-1,2,7-triol (hyacinthacine $B_{4}$ ) (4). Following the general method for hydrogenolysis of benzyl ethers, the alcohol 32 (8.4 mg, $0.018 \mathrm{mmol})$ was treated with $\mathrm{PdCl}_{2}(4.8 \mathrm{mg}, 0.027 \mathrm{mmol})$ and $\mathrm{MeOH}(1.4 \mathrm{~mL})$ at $\mathrm{rt}\left(22^{\circ} \mathrm{C}\right)$ for $3 \mathrm{~h}$. The title compound (3.6 $\left.\mathrm{mg}, 100 \%\right)$ was obtained as a colorless film. $[\alpha]_{D}^{25}-7.7\left(c\right.$ 0.18, $\left.\mathrm{H}_{2} \mathrm{O}\right)$. $\left[\mathrm{Lit}^{3 \mathrm{C}}{ }^{3 \mathrm{C}}[\alpha]_{D}-6.7\left(c\right.\right.$ 1.19, $\left.\mathrm{H}_{2} \mathrm{O}\right)$, temperature not reported]. IR $v_{\max }\left(\mathrm{cm}^{-1}\right):$ 3291, 2930, 2882, 1637, 1592, 1384, 1343, 1137, 1064, 612. $\delta_{\mathrm{H}}\left(500 \mathrm{MHz}, \mathrm{D}_{2} \mathrm{O}\right): 4.44(1 \mathrm{H}, \mathrm{td}, J=6.4,5.7 \mathrm{~Hz}, \mathrm{H} 7), 4.16(1 \mathrm{H}, \mathrm{dd}, J=7.8,7.3 \mathrm{~Hz}, \mathrm{H} 1)$, 3.97 (1H, dd, $J=7.8,7.0 \mathrm{~Hz}, \mathrm{H} 2), 3.69(2 \mathrm{H}, \mathrm{d}, J=5.4 \mathrm{~Hz}, \mathrm{H} 8), 3.30$ (1H, dd, $J=7.3,6.8$ Hz, H7a), 3.28 - 3.24 (1H, m, H5), 3.14 (1H, dt, $J=7.8,5.4$ Hz, H3), 2.14 (1H, dt, $J=$ 13.2, $\left.5.7 \mathrm{~Hz}, \mathrm{H6} 6_{\beta}\right), 1.71$ (1H, ddd, $J=13.2,7.3,6.4 \mathrm{~Hz}, \mathrm{H6} \alpha$ ), 1.26 (3H, d, $J=7.3 \mathrm{~Hz}$, H9). $\delta_{\mathrm{C}}\left(125 \mathrm{MHz}, \mathrm{D}_{2} \mathrm{O}\right.$ ): 82.0 (C2), 77.1 (C1), 73.1 (C7), 72.9 (C7a), 66.0 (C8), 64.5 (C3), 57.0 (C5), 42.7 (C6), 19.0 (C9). ESIMS m/z 204 (100\%) [M+H] $]^{+}$. HRASAPMS found 204.1246, calcd for $\mathrm{C}_{9} \mathrm{H}_{18} \mathrm{NO}_{4}, 204.1236[\mathrm{M}+\mathrm{H}]^{+}$.

(1S,2R,3R,5R,7R,7aS)-3-(Hydroxymethyl)-5-methylhexahydro-1H-pyrrolizine-1,2,7-triol (7a-epi-hyacinthacine $B_{3}$ ) (33). Following the general method for hydrogenolysis of benzyl ethers, the alcohol 30 (2.3 mg, $0.005 \mathrm{mmol}$ ) was treated with $\mathrm{PdCl}_{2}(1.3 \mathrm{mg}, 0.008$ mmol), and $\mathrm{MeOH}(0.5 \mathrm{~mL})$ at $\mathrm{rt}\left(24{ }^{\circ} \mathrm{C}\right)$. The title compound $(1.0 \mathrm{mg}, 100 \%)$ was obtained as a colorless film. $[\alpha]_{D}^{25}-5.3\left(c 0.11, \mathrm{H}_{2} \mathrm{O}\right)$. IR $v_{\max }\left(\mathrm{cm}^{-1}\right)$ : 3294, 2967, 1649, 1552, 1405, 1083, 1044. $\delta_{\mathrm{H}}\left(500 \mathrm{MHz}, \mathrm{D}_{2} \mathrm{O}\right): 4.38(1 \mathrm{H}, \mathrm{t}, J=3.9 \mathrm{~Hz}, \mathrm{H} 7), 4.26(1 \mathrm{H}, \mathrm{dd}, J$ = 4.4, $3.9 \mathrm{~Hz}, \mathrm{H1}), 4.08$ (1H, dd, $J=7.3,4.9 \mathrm{~Hz}, \mathrm{H} 2), 3.97(1 \mathrm{H}, \mathrm{dd}, J=12.7,6.8 \mathrm{~Hz}$, H8 ${ }_{\mathrm{A}}$ ), 3.89 (1H, dd, $\left.J=12.7,3.9 \mathrm{~Hz}, \mathrm{H}_{\mathrm{B}}\right), 3.59$ (1H, dd, $\left.J=4.4,3.9 \mathrm{~Hz}, \mathrm{H7a}\right), 3.51$, (1H, ddd, $J=5.9,4.4,3.9 \mathrm{~Hz}, \mathrm{H} 5), 3.23$ (1H, ddd, $J=6.8,4.9,3.9 \mathrm{~Hz}, \mathrm{H3}$ ), 2.05 (1H, ddd, $J=$ 
13.2, 4.4, $3.9 \mathrm{~Hz}, \mathrm{H6}_{\beta}$ ), 1.71 (1H, ddd, $J=13.2,11.2,4.4 \mathrm{~Hz}, \mathrm{H}_{\alpha}$ ), $1.22(3 \mathrm{H}, \mathrm{d}, J=5.9$ Hz, H9). $\delta_{\mathrm{C}}\left(125 \mathrm{MHz}, \mathrm{D}_{2} \mathrm{O}\right): 77.5$ (C7a), 76.4 (C2), 72.1 (C7), 72.0 (C1), 66.8 (C3), 61.4 (C8), 55.2 (C5), 46.3 (C6), 22.0 (C9). ESIMS m/z 204 (100\%) [M+H] $]^{+}$. HRASAPMS found 204.1234, calcd for $\mathrm{C}_{9} \mathrm{H}_{18} \mathrm{NO}_{4}, 204.1236[\mathrm{M}+\mathrm{H}]^{+}$. (1R,3R,5R,6R,7S,7aR)-6,7-Bis(benzyloxy)-5-(benzyloxymethyl)-3-methylhexahydro-1Hpyrrolizin-1-yl 4-nitrobenzoate (36). Following the general method for the Mitsunobu reaction, the alcohol 21 (144 $\mu$ g, $0.30 \mathrm{mmol}$ ) was treated with triphenylphosphine (354 mg, $1.35 \mathrm{mmol}$ ), p-nitrobenzoic acid (226 mg, $1.35 \mathrm{mmol}$ ) and diisopropyl azodicarboxylate (266 $\mu \mathrm{L}, 3.96 \mathrm{mmol})$ in toluene $(3 \mathrm{~mL})$ at $80{ }^{\circ} \mathrm{C}$ for $2 \mathrm{~d}$. Purification by flash column chromatography (20:70 to 50:50 EtOAc/petrol as eluent) gave the title compound (ca 70\% pure) (40 mg) as a yellow film and recovered 21 (45.5 mg, 32\%) was also isolated. $R_{f} 0.60\left(5: 95 \mathrm{MeOH} / \mathrm{CH}_{2} \mathrm{Cl}_{2}\right)$. IR $v_{\max }\left(\mathrm{cm}^{-1}\right)$ : 2921, 2854, 1722, 1527, $1347,1273,1103,1027,736,697 . \delta_{\mathrm{H}}\left(500 \mathrm{MHz}, \mathrm{CDCl}_{3}\right): 8.28(2 \mathrm{H}, \mathrm{d}, J=8.8 \mathrm{~Hz}), 8.16$ $(2 \mathrm{H}, \mathrm{d}, J=8.8 \mathrm{~Hz}), 7.37-7.22(15 \mathrm{H}, \mathrm{m}), 5.77(1 \mathrm{H}, \mathrm{dt}, J=7.3,4.1 \mathrm{~Hz}), 4.75(1 \mathrm{H}, \mathrm{d}, J=$ $11.7 \mathrm{~Hz}), 4.64$ - 4.47 (5H, m), 4.19 (1H, dd, $J=5.3,4.1 \mathrm{~Hz}), 3.93$ (1H, s (br)), $3.78(1 \mathrm{H}$, dd, $J=5.3,3.2 \mathrm{~Hz}$ ), 3.68 - 3.60 (1H, m), 3.42 (3H, s (br)), 2.01 (2H, m), 1.27 (3H, d, $J=$ $6.2 \mathrm{~Hz}) . \delta_{\mathrm{C}}(125 \mathrm{MHz}): 164.4(\mathrm{CO}), 150.6$ (ArC), 138.3 (2 x ArC), 138.2 (ArC), 135.7 (ArC), 130.8 (2 x ArCH), 128.7 (2 x ArCH), 128.5 (4 x ArCH), 127.9 (3 x ArCH), 127.8 (5 x ArCH), 127.7 (2 x ArCH), 123.6 (ArCH), 81.4 (C2), 76.9 (C1), 76.1 (C7, br), 73.5 ( $\left(\mathrm{CH}_{2}\right), 73.4\left(\mathrm{CH}_{2}\right), 72.6\left(\mathrm{CH}_{2}\right), 72.4$ (C8), 60.1 (C3), 56.7 (C5), 39.8 (C6), 22.1 (C1). ESIMS $\mathrm{m} / \mathrm{z} 623(100 \%)[\mathrm{M}+\mathrm{H}]^{+}$. HRESIMS found 623.2737, calcd for $\mathrm{C}_{37} \mathrm{H}_{39} \mathrm{~N}_{2} \mathrm{O}_{7}$, $623.2757[\mathrm{M}+\mathrm{H}]^{+}$. 
(1R,3R,5R,6R,7S,7aS)-6,7-Bis(benzyloxy)-5-(benzyloxymethyl)-3-methylhexahydro-1Hpyrrolizin-1-yl methanesulfonate (37). Following the general method for mesylationcyclization, the alcohol 21 (16.8 mg, $0.034 \mathrm{mmol})$ was treated with triethylamine (81 $\mu \mathrm{L}$, $0.58 \mathrm{mmol})$, methanesulfonyl chloride $(184 \mu \mathrm{L}, 2.38 \mathrm{mmol})$ and $\mathrm{CH}_{2} \mathrm{Cl}_{2}(1.5 \mathrm{~mL})$ at $\mathrm{rt}$ for $24 \mathrm{~h}$. Purification by flash column chromatography $\left(0: 100\right.$ to $5: 95 \mathrm{MeOH} / \mathrm{CH}_{2} \mathrm{Cl}_{2}$ as eluent) gave the title compound (16.5 mg, $87 \%)$ as a colorless oil. $R_{f} \quad 0.67$ (5:95 $\left.\mathrm{MeOH} / \mathrm{CH}_{2} \mathrm{Cl}_{2}\right) .[\alpha]_{D}^{25}-10.5\left(c\right.$ 0.16, $\left.\mathrm{CHCl}_{3}\right) . \mathrm{IR} v_{\max }\left(\mathrm{cm}^{-1}\right): 3063,3030,2929,2866$, 1453, 1351, 1174, 1116, 1026, 935, 895, 697. $\delta_{\mathrm{H}}\left(500 \mathrm{MHz}, \mathrm{CDCl}_{3}\right): 7.35-7.25(15 \mathrm{H}$, m), 5.50 - $5.49(1 \mathrm{H}, \mathrm{m}), 4.59$ - $4.44(6 \mathrm{H}, \mathrm{m}), 4.22(1 \mathrm{H}, \mathrm{dd}, J=5.9,4.9 \mathrm{~Hz}), 3.89(1 \mathrm{H}, \mathrm{s}$ (br)), 3.66 - $3.64(1 \mathrm{H}, \mathrm{m}), 3.56$ - $3.49(1 \mathrm{H}, \mathrm{m}), 3.33(1 \mathrm{H}, \mathrm{dd}, J=8.5,4.4 \mathrm{~Hz}), 3.28$ - 3.25 (1H, m), 3.20 (1H, dd, $J=8.5,7.8 \mathrm{~Hz}$ ), 2.81 (3H, s), 2.06 (1H, dd, $J=13.7,4.9 \mathrm{~Hz}), 1.93$ - $1.86(1 \mathrm{H}, \mathrm{m}), 1.19(3 \mathrm{H}, \mathrm{d}, J=6.8 \mathrm{~Hz}) . \delta_{\mathrm{C}}\left(75 \mathrm{MHz}, \mathrm{CDCl}_{3}\right): 138.3(\mathrm{ArC}), 137.9(2 \mathrm{x}$ ArC), 132.2 (2 x $\mathrm{ArCH}), 128.5$ ( $\mathrm{ArCH}), 128.2$ (4 x $\mathrm{ArCH}), 128.0$ (2 x ArCH), 127.9 (4 x ArCH), 127.8 (2 x ArCH), 83.3 (C7), 79.2 (C2), 77.2 (C1), $73.6\left(\mathrm{CH}_{2}\right), 73.4$ (C7a), 72.9 ( $\left(\mathrm{CH}_{2}\right), 72.4$ (C8), $71.6\left(\mathrm{CH}_{2}\right), 60.6$ (C3), 56.8 (C5), 39.9 (C6), 37.7 (Me), 15.5 (C9). ESIMS $\mathrm{m} / \mathrm{z} 552(100 \%)[\mathrm{M}+\mathrm{H}]^{+}$. HRESIMS found 552.2418, calcd for $\mathrm{C}_{31} \mathrm{H}_{38} \mathrm{NO}_{6} \mathrm{~S}$, $552.2420[\mathrm{M}+\mathrm{H}]^{+}$. (1R,3R,5R,6R,7S,7aR)-6,7-Bis(benzyloxy)-5-(benzyloxymethyl)-3-methylhexahydro-1Hpyrrolizin-1-yl benzoate (38). A solution of the mesylate 36 (31 $\mathrm{mg}, 0.06 \mathrm{mmol})$ in DMSO (6 mL) was stirred at rt for $5 \mathrm{~min}$ and then cesium benzoate (26 mg, $0.11 \mathrm{mmol}$ ) was added. The reaction mixture was stirred at $70{ }^{\circ} \mathrm{C}$ for $2 \mathrm{~d}$. After the reaction mixture had cooled to rt, a satd aqu solution of $\mathrm{Na}_{2} \mathrm{CO}_{3}(5 \mathrm{~mL})$ was added and then extracted with $\mathrm{Et}_{2} \mathrm{O}(3 \times 20 \mathrm{~mL})$, dried $\left(\mathrm{MgSO}_{4}\right)$ and concentrated in vacuo to give a light brown film. 
Purification by flash column chromatography (increasing polarity from 5:95 to 20:80 of EtOAc/ $\mathrm{CH}_{2} \mathrm{Cl}_{2}$ as eluent) gave the title compound (14 mg, 42\%) as a colorless film. $R_{f}$ $0.20\left(2: 98 \mathrm{MeOH} / \mathrm{CH}_{2} \mathrm{Cl}_{2}\right) .[\alpha]_{D}^{25}-18.7\left(c\right.$ 0.28, $\left.\mathrm{CHCl}_{3}\right) . \mathrm{IR} v_{\max }\left(\mathrm{cm}^{-1}\right): 3063,3031$, 2924, 2862, 1715, 1452, 1358, 1273, 1111, 1025, 736, 696. $\delta_{\mathrm{H}}\left(500 \mathrm{MHz}, \mathrm{CDCl}_{3}\right): 8.01$ (2H, d, $J=7.8 \mathrm{~Hz}), 7.52(1 \mathrm{H}, \mathrm{t}, J=7.3 \mathrm{~Hz}), 7.42(2 \mathrm{H}, \mathrm{dd}, J=7.8,7.3 \mathrm{~Hz}), 7.33-7.22$ (15H, m), 5.75 - $5.72(1 \mathrm{H}, \mathrm{m}), 4.74(1 \mathrm{H}, \mathrm{d}, J=11.7 \mathrm{~Hz}), 4.67(1 \mathrm{H}, \mathrm{d}, J=11.7 \mathrm{~Hz}), 4.62$ $(1 \mathrm{H}, \mathrm{d}, J=11.7 \mathrm{~Hz}), 4.56(1 \mathrm{H}, \mathrm{d}, J=12.2 \mathrm{~Hz}), 4.51(1 \mathrm{H}, \mathrm{d}, J=11.7 \mathrm{~Hz}), 4.49(1 \mathrm{H}, \mathrm{d}, J=$ $12.2 \mathrm{~Hz}), 4.18(1 \mathrm{H}, \mathrm{dd}, J=4.9,3.9 \mathrm{~Hz}), 3.92(1 \mathrm{H}, \mathrm{t}, J=3.9 \mathrm{~Hz}), 3.78(1 \mathrm{H}, \mathrm{s}(\mathrm{br})), 3.66$ $3.62(1 \mathrm{H}, \mathrm{m}), 3.43(3 \mathrm{H}, \mathrm{s}(\mathrm{br})), 2.02-2.00(2 \mathrm{H}, \mathrm{m}), 1.22(3 \mathrm{H}, \mathrm{d}, J=6.8 \mathrm{~Hz}) . \delta_{\mathrm{C}}(125$ MHz, CDCl $)$ ): 166.4 (CO), 138.6 (2 x ArC), 138.4 (ArC), 133.0 (2 x ArCH), 130.7 (ArC), 129.7 (2 x $\mathrm{ArCH}), 128.4$ (4 x $\mathrm{ArCH}), 127.9$ (2 x $\mathrm{ArCH}), 127.8$ (4 x $\mathrm{ArCH}), 127.7$ (2 x ArCH), 127.6 (2 x ArCH), 81.7 (C2), 76.9 (C1), 75.6 (C7), $73.5\left(\mathrm{CH}_{2}\right), 73.3\left(\mathrm{CH}_{2}\right), 72.5$ (C7a and $\mathrm{CH}_{2}$ ), 72.2 (C8), 59.9 (C3), 56.4 (C5), 39.9 (C6), 16.2 (C9). ESIMS m/z 578 $[\mathrm{M}+\mathrm{H}]^{+}$. HRESIMS found 578.2902, calcd for $\mathrm{C}_{37} \mathrm{H}_{40} \mathrm{NO}_{5}, 578.2906[\mathrm{M}+\mathrm{H}]^{+}$.

\section{ASSOCIATED CONTENT}

\section{Supporting Information}

Comparative tables of the ${ }^{1} \mathrm{H}$ and ${ }^{13} \mathrm{C}$ NMR spectroscopic data of synthetic and natural samples of compounds 2-6, copies of the ${ }^{1} \mathrm{H}$ and ${ }^{13} \mathrm{C}$ NMR spectra of all new compounds, and NOESY spectra of compounds 2-6 and 33. This material is available free of charge via the Internet at http://pubs.acs.org/.

\section{AUTHOR INFORMATION}

\section{Corresponding Author}


*E-mail: spyne@uow.edu.au

\section{Notes}

The authors declare no competing financial interest.

\section{ACKNOWLEDGMENTS}

This research is funded by the Australian Research Council. K.S. thanks The Royal Thai Government under The Ministry of Science and Technology scholarship for full financial support of his PhD program

\section{REFERENCES}

(1) (a) Asano, N. in Modern Alkaloids: Structure, Isolation, Synthesis and Biology, E. Fattorusso, E.; Taglialatela-Scafati, O., Eds. Wiley-VCH Verlag, Weinheim, 2008; pp 111-138. (b) Nash, R. J.; Kato, A.; Yu, C.; Fleet, G. W. J. Future Med. Chem. 2011, 3, $1513-1521$.

(2) For reviews on their synthesis see: (a) Pyne, S. G.; Tang, M. Curr. Org. Chem. 2005, 9, 1393-1418. (b) Lopez, M. D.; Cobo J.; Nogeuras, M. Curr. Org. Chem. 2008, 12, 718-750 (c) Ritthiwigrom, T.; Au, C. W. G.; Pyne, S. G. Curr. Org. Syn. 2012, 9, $583-612$.

(3) (a) Kato, A.; Adachi, I.; Miyauchi, M.; Ikeda, K.; Komae, T.; Kizu, H.; Kameda, Y.; Watson, A. A.; Nash, R. J.; Wormald, M. R.; Fleet G. W. J.; Asano, N., Carbohyd. Res., 1999, 316, 95-103. (b) Asano, N.; Kuroi, H.; Ikeda, K.; Kizu, H.; Kameda, Y.; Kato, A.; Adachi, I.; Watson, A. A.; Nash R. J.; Fleet, G. W. J. Tetrahedron: Asymmetry, 2000, 11, 1-8 (c) Yamashita, T.; Yasuda, K.; Kizu, H.; Kameda, Y.; Watson, A. A.; Nash, R. J.; Fleet G. W. J.; Asano, N. J. Nat. Prod., 2002, 65, 1875-1881. (d) Kato, A.; 
Kato, N.; Adachi, I.; Hollinshead, J.; Fleet, G. W. J.; Kuriyama, C.; Ikeda, K.; Asano, N.; Nash, R. J. J. Nat. Prod., 2007, 70, 993-997. (e) Asano, N.; Ikeda, K.; Kasahara, M.; Arai Y.; Kizu, H. J. Nat. Prod., 2004, 67, 846-850.

(4) Donohoe, T. J.; Thomas, R. E.; Cheeseman, M. D.; Rigby, C. L.; Bhalay G.; Linney, I. D. Org. Lett., 2008, 10, 3615-3618.

(5) (a) Ramabaud, L.; Compain, P.; Martin, O. R. Tetrahedron: Asymmetry, 2001, 12, 1807-1809. (b) Izquierdo, I.; Plaza, M. T.; Robles R.; Franco, F. Tetrahedron: Asymmetry, 2002, 13, 1581-1585. (c) Cardona, F.; Faggi, E.; Liguori, F.; Cacciarini, M.; Goti, A. Tetrahedron Lett. 2003, 44, 2315-2318. (d) Izquierdo, I.; Plaza, M. T.; Franco, F. Tetrahedron: Asymmetry 2003, 14, 3933-3935. (e) Desvergnes, S.; Py, S.; Valée, Y. J. Org. Chem. 2005, 70, 1459-1462. (f) Chabaud, L.; Landais, Y.; Renaud, P. Org. Lett. 2005, 7, 2587-2590. (g) Izquierdo, I.; Plaza, M. T.; Tamayo, J. A.; Sanchaz-Cantalejo, F. Tetrahedron: Asymmetry 2007, 18, 2211-2217. (h) Izquierdo, I.; Plaza, M. T.; Tamayo, J. A.; Yanez, V.; Re D. L.; Sanchaz-Cantalejo, F. Tetrahedron, 2008, 64, 4613-4618 (i) Zhang, T.-X.; Zhou, L.; Cao, X.-P. Chem. Res. Chinese Universities 2008, 24, 469-472. (j) Izquierdo, I.; Plaza, M. T.; Tamayo, J. A.; Franco, F.; Sanchaz-Cantalejo, F. Tetrahedron 2010, 66, 3788-3794. (k) Delso, I.; Tejero, T.; Goti, A.; Merino, P. Tetrahedron 2010, 66, 1220-1227. (l) Hu, X-G.; Jia, Y-M.; Xiang, J.; Yu, C-Y.; Synlett 2010, 982-986. (m) Tamayo, J. A.; Franco, F.; Sáanchez-Cantalejo, F. Tetrahedron 2010, 66, 7262-7267. (n) Zhang, W.; Sato, K.; Kato, A.; Jia, Y.; Hu, X.; Wilson, F. X.; Well, R.; Horne, G.; Fleet, G. W. J.; Nash, R. J.; Yu, C. Org. Lett. 2011, 13, 4414-4417. (o) D’Adamio, G.; Goti, A.; Parmeggiani, C.; Moreno-Clavijo, E.; Robina, I.; Cardona, F. Eur. J. Org. Chem. 2011, 7155-7162. (p) Sengoku, T.; Satoh, Y.; Oshima, M.; 
Takahashi, M.; Yoda, H. Tetrahedron 2008, 64, 8052-8058. (q) Sengoku, T.; Satoh, Y.; Takahashi, M.; Yoda, H. Tetrahedron Lett. 2009, 50, 4937-4940. (r) Ribes, C.; Falomir, E.; Murga, J.; Carda, M.; Marco, J. A. Tetrahedron 2009, 65, 6965-6971. (s) Chandrasekhar, S.; Parida B. B.; Rambabu, C. J. Org. Chem. 2008, 73, 7826-7828. (t) Liu, X.-K.; Qiu, S.; Xiang, Y.-G.; Ruan, Y.-P.; Zheng, X.; Huang, P.-Q. J. Org. Chem. 2011, 76, 4952-4963. (u) Brock, E. A.; Davies, S. G.; Lee, J. A.; Roberts, P. M.; Thomson, J. E. Org. Biomol. Chem., 2013, 11, 3187-3202.

(6) Dewi-Wülfing, P.; Blechert, S. Eur. J. Org. Chem., 2006, 1852-1856.

(7) (a) Reddy, P. V.; Veyron, A.; Koos, P.; Bayle, A.; Greene, A. E.; Delair, P.

Org. Biomol. Chem., 2008, 6, 1170-1172. (b) Reddy, P. V.; Koos, P.; Veyron, A.; Greene, A. E.; Delair, P. Synlett, 2009, 1141-1143. (c) Reddy, P. V.; Smith, J.; Kamath, A.; Jamet, H.; Veyron, A; Koos, P.; Philouze, C.; Greene, A. E.; Delair, P. J. Org. Chem. 2013, 78, 4840-4849.

(8) Calveras, J.; Casas, J.; Parella, T.; Joglar, J.; Clapés, P. Adv. Synth. Catal., 2007, $349,1661-1666$.

(9) (a) Izquierdo, I.; Plaza, M. T.; Franco, F. Tetrahedron: Asymmetry 2002, 13, 1581-1585. (b) Izquierdo, I.; Plaza, M. T.; Franco, F. Tetrahedron: Asymmetry 2004, 15, 1465-1469. (c) Izquierdo, I.; Plaza, M. T.; Tamayo, J. A.; Rodriguez, M.; Martos, A. Tetrahedron 2006, 62, 6006-6011. (d) Zhou, L. Chen J. Cao X.-P. Synthesis 2007, 1359-1365. (e). Kaliappan K. P.; Das, P. Synlett 2008, 6, 841-844. (f) Tamayo, J. A.; Franco, F.; Sánchez-Cantalejo, F. Eur. J. Org. Chem. 2011, 7182-7188. (g) Rajender, A.; Rao, J. P.; Rao, B. V. Eur. J. Org. Chem. 2013, 1749-1757. (h) Martella, D.; Cardona, F.; Parmeggiani, C.; Franco, F.; Tamayo, J. A.; Robina, I.; Moreno-Clavijo, E.; Moreno- 
Vargas, A. J.; Goti, A. Eur. J. Org. Chem. 2013, 4047-4056. (i) Marjanovic, J.; Divjakovic, V.; Matovic, R.; Ferjancic, Z.; Saicic, R. N. Eur. J. Org. Chem. 2013, $5555-5560$.

(10) Donohoe, T. J.; Sintim H. O.; Hollinshead, J. J. Org. Chem., 2005, 70, $7297-7304$.

(11) Au, C. W. G.; Nash, R. J.; Pyne, S. G. Chem. Commun. 2010, 46, 713-715.

(12) Evans P.; Leffray, M. Tetrahedron, 2003, 59, 7973-7987.

(13) Trost, B. M.; Bunt, R. C.; Lemoine, R., C.; Calkins, T. L. J. Am. Chem. Soc. 2000, 122, 5968-5976.

(14) (a) Petasis N. A.; Zavialov, I. A. J. Am. Chem. Soc., 1998, 120, 11798-11799. (b) A` S. Davis, A. S.; Pyne, S. G.; Skelton, B. W.; White, A. H. J. Org. Chem., 2004, 69, 3139-3143. (c) Au C. W. G.; Pyne, S. G. J. Org. Chem. 2006, 71, 7097-7099. (d) Ritthiwigrom, T.; Willis, A. C.; Pyne, S. G. J. Org. Chem. 2010, 75, 815-824. (e) Jiangseubchatveera, N.; Bouillon, M. E.; Liawruangrath, B.; Liawruangrath, S.; Nash, R. J.; Pyne, S. G. Org. Biomol. Chem. 2013, 11, 3826-3833. (f) Bouillon, M. E.; Pyne, S. G. Tetrahedron Lett. 2014, 55, 475-478.

(15) Crispino, G. A.; Jeong, K.; Kolb, H. C.; Wang, Z.; Xu, D.; Sharpless, K. B. J. Org. Chem. 1993, 58, 3785-3786.

(16) Siedlecka, R.; Skarzewski, J.; Mlochowshi, J. Tetrahedron Lett. 1990, 31, $2177-2180$.

(17) Tang M.; Pyne, S. G. J. Org. Chem. 2003, 68, 7818-7824.

(18) (a) Davis, A. S.; Gates, N. J.; Lindsay, K. B.; Tang M.; Pyne, S. G. Synlett, 2004, 49-52. (b) Murray, A. J.; Parsons, P. J.; Greenwood E. S.; Viseux, E. M. E. Synlett, 2004, 
1589-1591 (c) Murray, A. J.; Parsons P. J.; Hitchcock, P. B. Tetrahedron, 2007, 63, 6485-6492.

(19) Machan, T.; Davis, A. S.; Liawruangrath B.; Pyne, S. G. Tetrahedron, 2008, 64, $2725-2732$.

(20) Martin, S. F.; Dodge, J. A. Tetrahedron Lett. 1991, 3017-3020.

(21) Mancuso, A. J.; Swern, D. Synthesis 1981, 3, 165-185.

(22) Dijkstra, G.; Kruizinga, W. H.; Kellogg, R. M. J. Org. Chem. 1987, 52, $4230-4234$.

(23) (a) Ahn, C.; Correia, R.; DeShong, P. J. Org. Chem. 2002, 67, 1751-1753. (b)

Swamy, K. C. K.; Kumar, N. N. B.; Balaraman, E.; Kumar, K. V. P. P., Chem. Rev. 2009, 109, 2551-2651.

(24) For the formation of aziridinium ion intermediates in related systems see: Krow, G. R.; Edupuganti, R.; Gandla, D.; Choudhary, A.; Lin, G.; Sonnet, P. E.; De Brosse, C.; Ross, C. W.; Cannon, K. C.; Raines, R. T. J. Org. Chem. 2009, 74, 8232-8242. 